\title{
The role of West Virginia University in the economic development of West Virginia: A general equilibrium approach
}

Priyanjali Sinha

Follow this and additional works at: https://researchrepository.wvu.edu/etd

\section{Recommended Citation}

Sinha, Priyanjali, "The role of West Virginia University in the economic development of West Virginia: A general equilibrium approach" (2016). Graduate Theses, Dissertations, and Problem Reports. 6648. https://researchrepository.wvu.edu/etd/6648

This Dissertation is protected by copyright and/or related rights. It has been brought to you by the The Research Repository @ WVU with permission from the rights-holder(s). You are free to use this Dissertation in any way that is permitted by the copyright and related rights legislation that applies to your use. For other uses you must obtain permission from the rights-holder(s) directly, unless additional rights are indicated by a Creative Commons license in the record and/ or on the work itself. This Dissertation has been accepted for inclusion in WVU Graduate Theses, Dissertations, and Problem Reports collection by an authorized administrator of The Research Repository @ WVU. For more information, please contact researchrepository@mail.wvu.edu. 


\title{
The Role OF West Virginia University in the ECONOMiC DEVELOPMENT OF \\ West Virginia: A GeNERAL EQUILIBRIUM APPROACH
}

\section{Priyanjali Sinha}

\author{
Dissertation SUbmitTED to the Davis College of Agriculture, NATURAL \\ RESOURCES AND DESIGN \\ AT WEST ViRgINIA UNIVERSITY
}

\author{
DOCTOR OF PHILOSOPHY IN \\ NATURAL RESOURCE ECONOMICS \\ Tesfa Gebremedhin, Ph.D., Chair \\ Peter SchaefFer, Ph.D. \\ Donald Lacombe, Ph.D. \\ Michael StRager, Ph.D. \\ Michael Dougherty, Ph.D.
}

IN PARTIAL FULFILMENT OF THE REQUIREMENTS FOR THE DEGREE OF

Division OF RESOURCE MANAGEMENT

Morgantown, West Virginia

2016

Keywords: University Spillover, Human CAPITAl Spillover, KNowledge SPILlover, ECONOMiC

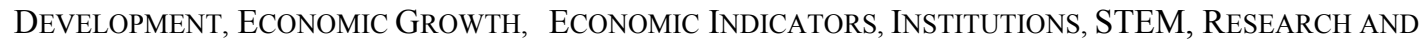
Development, Spatial Analysis, Panel Fixed EfFects.

COPYRIGHT 2016 PRIYANJALI SinHA 


\title{
ABSTRACT
}

\section{The Role Of West Virginia UNIVERSITY In THE ECONOMIC DEVElopMent OF WeST VIRGINIA: A GENERAL EQUILIBRIUM APPROACH}

\author{
PriYanjali Sinha
}

Universities, industries and government are major institutions and play an important role in local economic growth and development. They often work collectively in achieving these goals. While the role of institutions in economic development is well-founded in the literature, a university's strategic role as an institution to encourage local area development is only now being recognized. The existing literature recognizes the spillover effect of mainly university research on local industrial productivity and innovations at the national level. The impact of various university activities on numerous other local economic development indicators like per capita income, poverty, school enrollments etc., at county level has not been attempted. That is, the impact of a university on the local economic development beyond industry research and development and the interaction between the major institutions in this context-namely, university, local business, local community and government remains unexplored. The identification of these interactions have the potential to guide policy makers in devising economic policies and formulating budgetary plans.

To extend the existing literature, this research develops a static general equilibrium model of the local economy to assess the impact of diverse activities of West Virginia University, using the holistic approach suggested by Hoffman and Hill (2009) and other existing literature. The analysis is based on the county level data of West Virginia for 55 counties over the period of seven years from 2001-2007. The study controls for other influencing factors on economic development like community, industry and government. Based on previous studies, the analysis identifies spatial dependence as a factor of university spillovers to local areas. Thus, the study uses both spatial and non-spatial models for analysis. The non-spatial models employed consist of Least Square Dummy Variable regression (LSDV), Fixed Effects Panel Regression and Seemingly Unrelated Regressions (SUR) Panel Fixed Effects Model. Following Elhorst's (2010) testing procedure, the Spatial Durbin Model (SDM) is employed for spatial analysis.

The results are interpreted for policy analysis considering the limitations of the model and the available data. The results find positive university spillover on the economic development indicators: Per Capita Income, Poverty, Public School Enrollment, Patents, Industrial Wages and Earnings. The empirical models estimated in this study identify the various channels through which a university impacts the local economy. The study concludes, the impact of West Virginia University has a significant influence on all the economic development parameters measured in this analysis. This positive stimulus will be larger with greater industrial collaborations in terms of research. Furthermore, broader government support in terms of grants for high-tech research and development and providing a positive economic environment for fortifying industrial connections will result in sustainable economic growth and development. 


\section{DEDICATIONS}

I dedicate this endeavor to my husband, Saurabh C. Datta and my late father, Shyamol K. Sinha. 


\section{ACKNOWLEDGMENTS}

I would like to thank my advisor, Dr. Tesfa Gebremedhin for his vital guidance and mentorship throughout the entire course of my graduate education and dissertation process. Many thanks to my dissertation committee members, Dr. Peter Schaeffer, Dr. Donald Lacombe, Dr. Michael Strager and Dr. Michael Dougherty for their valuable time, comments, suggestions and for being such inspiring educators.

I am grateful for the graduate research assistantship granted to me by the Davis College of Agriculture, Natural Resources, and Design, Division of Resource Management.

Special thanks extended to Dr. Jerald Fletcher, Dr. Gerard D'Souza and the graduate committee for giving me the opportunity to achieve this degree.

I would like to thank Lisa Lewis and Ellen-Hartley Smith for their administrative assistance during my study in the division and extend my appreciation to my fellow colleagues and friends in the division for their encouragement and friendship.

I would also like to acknowledge Dr. Jeffery Nugent and Dr. Samar Datta for their valuable comments and suggestions.

Lastly, but most importantly, I would like to thank my husband, Saurabh Charles Datta for being my strength, my mother Anima Sinha for showing me the value of courage and my brother Shayan Sinha for inspiring me through his hard work and perseverance. 


\section{TABLE OF CONTENTS}

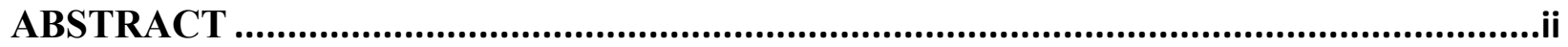

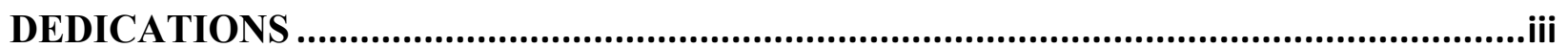

ACKNOWLEDGMENTS ...............................................................................................

TABLE OF CONTENTS …..............................................................................................

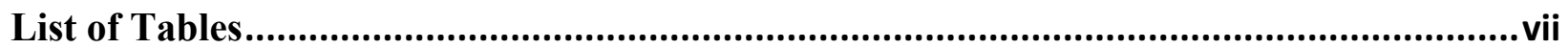

Chapter 1. INTRODUCTION............................................................................................ 1

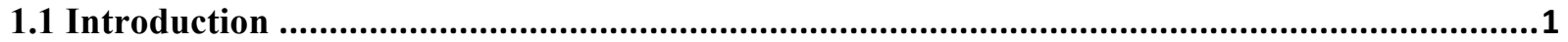

1.2 Hypotheses...................................................................................................4

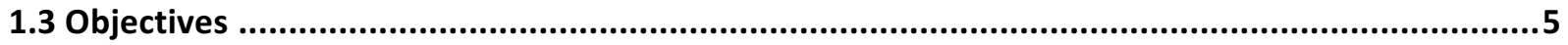

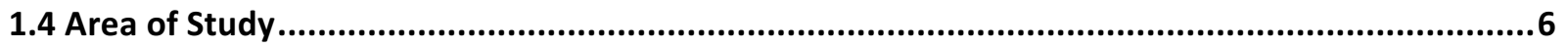

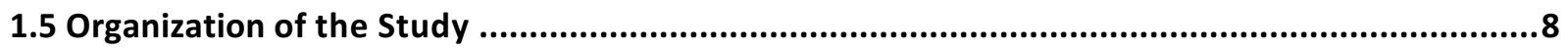

Chapter 2. LITERATURE REVIEW $\ldots \ldots \ldots \ldots \ldots \ldots \ldots \ldots \ldots \ldots \ldots \ldots \ldots \ldots \ldots \ldots \ldots \ldots \ldots \ldots \ldots \ldots \ldots \ldots \ldots \ldots \ldots \ldots \ldots \ldots \ldots . . . \ldots \ldots$

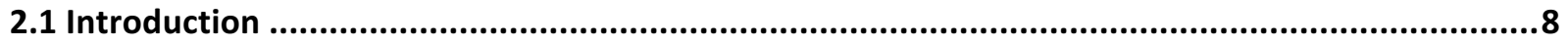

2.2 University Spillover on Industry Research and Development ...........................................9

2.3 University Spillover on Firm Startups .................................................................... 11

2.4 University Spillover on Industry Wages.....................................................................12

2.5 University Spillover on Industrial Clustering.................................................................. 12

2.6 University Spillover on Industrial Employment ...........................................................13

2.7 University Spillover on Industrial Productivity ......................................................... 14

2.8 University Spillover on Local Amenities .................................................................15

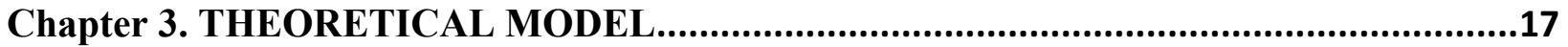

3.1 Introduction ................................................................................................... 17

3.2 University's Optimization Function ...................................................................... 18

3.3 Industry's Optimization Function ........................................................................ 25

3.4 Community's Optimization Function ......................................................................27

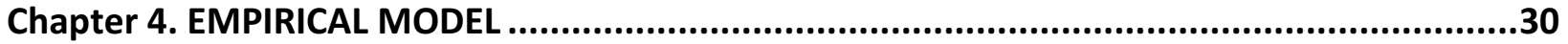

4.1 Non-Spatial Models.......................................................................................... 31

4.1.1 Specification 1: Least Square Dummy Variables .......................................................32

4.1.2 Specification 2A: Fixed Effects .........................................................................34

4.1.3 Specification 2B: Random Effects .............................................................................. 34

4.1.4 Specification 3: Seemingly Unrelated Regression in Panel Framework ...............................36

4.2 Spatial Models .............................................................................................. 37

4.2.1 Specification 4: Spatial Panel Durbin Model .........................................................40

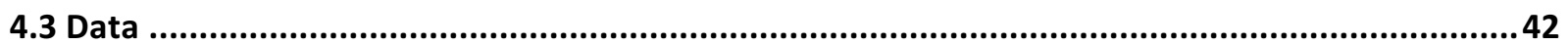




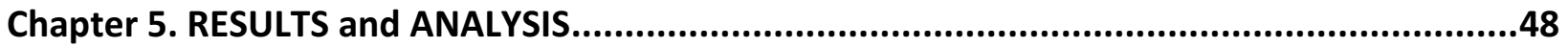

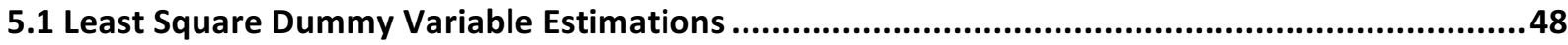

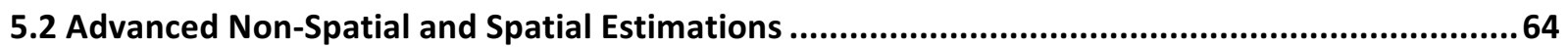

Chapter 6. SUMMARY and CONCLUSION ..............................................................77

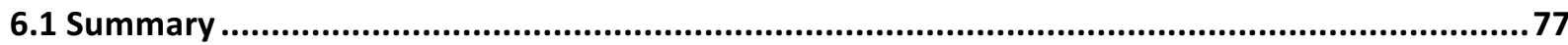

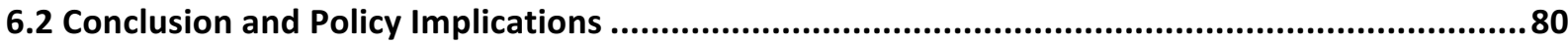

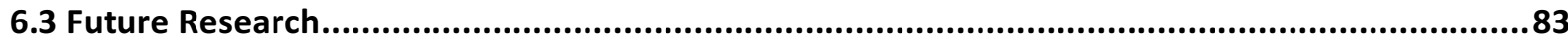

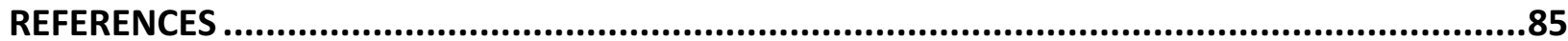

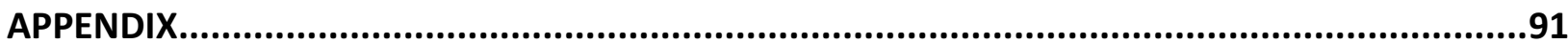

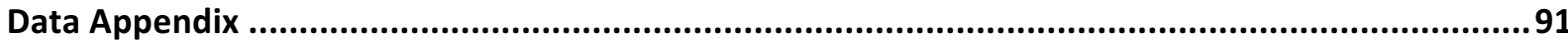

Result Appendix 


\section{List of Tables}

Table 1 Summary Statistics for Income Per capita Model ............................................... 43

Table 2 Summary Statistics for Total Average Industry Wage Model.............................. 44

Table 3 Summary Statistics for Poverty Rate Model ..................................................... 44

Table 4 Summary Statistics for Public School Enrollment Per Capita Model ................... 45

Table 5 Summary Statistics for Industrial Earnings Per Industrial Unit Model ................ 45

Table 6 Summary Statistics for Patents per STEM Industrial Unit Model ....................... 46

Table 7 Dependent Variable: Logarithm of Income per Capita ..................................... 50

Table 8 Dependent Variable: Logarithm of Total Average Wage in Industries................. 51

Table 9 Dependent Variable: Logarithm of Poverty Rate ............................................ 54

Table 10 Dependent Variable: Logarithm of Public School Enrollment Per Capita .......... 56

Table 11 Dependent Variable: Logarithm of Industrial Earnings per Industrial Unit ....... 57

Table 12 Dependent Variable: Patents per STEM Industrial Unit................................ 61

Table 13 Dependent Variable: Logarithm of Income per Capita ....................................6 67

Table 14 Dependent Variable: Logarithm of Total Average Industry Wage .................... 70

Table 15 Dependent Variable: Logarithm of Poverty Rate ............................................ 71

Table 16 Dependent Variable: Logarithm of Public School Enrollment Per Capita ........... 73

Table 17 Dependent Variable: Logarithm of Industrial Earnings per Industrial Units...... 74

Table 18 Dependent Variable: Patents per STEM Industrial Unit.................................... 76 


\section{Chapter 1. INTRODUCTION}

\subsection{Introduction}

Universities, private business enterprises and government work together to achieve local economic growth and development in terms of better education, new innovations, higher employment, better infrastructure, health facilities, local business development and sports and recreation. Most of the government activities are driven by political and economic considerations, whereas the role of a university is in developing and fostering talent, achieving innovations and generating local demand for goods and services that result in local economic growth. (Hoffman and Hill, 2009)

Investments by government, industry and university result in multiplier effects that promote economies of scale translating in growth of a region with possible spillover effect to other neighboring regions, thus attracting new industries into the area (Bacheller, 2000 and Porter, 2000). Most of the technological corridors which are among one of the largest employers like the Silicon Valley near Stanford University and the University of California, Berkeley, Boston Route 128 near Harvard and MIT, I-270 technological corridor near University of Maryland and John Hopkins University, the Research Triangle Park (RTP) near Duke University, University of North Carolina and North Carolina State University are clustered around universities. These areas have experienced high regional development in terms of income per capita, real estate, health, hi-tech infrastructure and businesses (Hausman, 2012).

A recent article published in The Economist (2016) identifies the upsurge in the economic growth in the city of Durham, North Carolina. The GDP per person increased 28\% since 2001 in Durham compared to just 3\% in North Carolina. The article attributes this growth to the location 
of the city, which is in close proximity to three major universities - Duke University, North Carolina State University and University of North Carolina. The population in the city of Durham grew by $7 \%$ between 2010 to 2014 . Whereas America's population grew by $3.1 \%$, its cities by $3.7 \%$ and the richest cities increased by $9.2 \%$. The inception of the Research Triangle Park encouraged the three universities to collaborate with each other and with local businesses which now employ 50,000 workers in the area. Consequently, resulting in the development of infrastructure like the overhaul of Raleigh-Durham airport, superior road maintenance and a future investment on light rail system in collaboration with local industries and the local government.

Similarly, in a research article, Andersson et al. (2004) find that the proximity to a university results in a $10 \%$ increase in the GDP of the economy, capturing the increase in productivity of workers. This is because the existence of universities produces a perpetual presence of highly educated individuals in high-tech fields in the economy. Thus, resulting in positive spillovers in terms of higher productivity and consequently increase in wages among less educated workers (Moretti, 2004). The proximity to college-educated workers increases wages up to $12 \%$, conversely the proximity to less than college educated workers has a negative effect on wages (Rosenthal and Strange, 2008). More specifically, if twice the workers are employed in Computer Science and Engineering, it boosts the productivity of workers in History and Arts by $19.2 \%$ and in Economics and Business by $17.5 \%$ (Liu,2014).

The presence of a university and its commercialization of research with local high technology industries induces new startups in the economy resulting in the formation of technological clusters similar to Route 128 and Silicon Valley (Bania, et al., 1993; Woodward et al., 2006). 
Universities also have a positive influence on other local area development indicators like real estate prices and local amenities. The presence of universities in a county has on an average 2.7\% higher real estate value from the counties that don't have a university present. Likewise, counties that have community colleges within their border have an $11.6 \%$ higher tax base than the ones without any colleges (Vandegrift, et al., 2012).

These studies further support the role of universities as one of the major institutions promoting economic growth. Though, some of the development parameters have been tested in the past literature, numerous other indicators remain to be measured for the presence of universities in an area. Therefore, it is imperative to study the impact of universities as an institution that promotes development through influencing various development parameters.

The role of institutions like government and industry on local economic development has been widely documented in the classical development economics literature (Adam Smith, 1776; John Stuart Mill, 1848; David Hume, 1948). Institutions collectively perform numerous vital functions in an economy that are imperative for its growth and development (Lin and Nugent, 1995). However, the role of universities as an institution remains relatively unexplored in terms of the mechanisms through which they influence growth and development in the local economy.

Furthermore, a certain degree of interdependency exists among the different functions of institutions, which is determined by the actions, nature and existence of surrounding institutions as well as prevailing local economic conditions. These interactions result in a multi agent interactive effect on the overall economy (Lin and Nugent, 1995). Thus requiring a holistic multi agent general equilibrium approach (Hoffman and Hill, 2009) after controlling for other economic and community features. 
Based on the multi-agent general equilibrium approach, a theoretical model is developed by taking into account the existing interdependencies between university and other institutions namely, government and industry. The theoretical model represents the process of how these interactions translate into local economic and industrial development after controlling for community characteristics.

The developed theoretical model is tested by employing empirical models using county level data of the state of West Virginia where West Virginia University is the institution promoting positive economic spillover into the local economy. The results indicate positive and significant impact of West Virginia University on the economic development indicators, broadly, Income per capita, Poverty Rate, Public School Enrollment, Industrial Wages, Industrial Earnings and Number of Patents.

Finally, it is concluded from this study that West Virginia University has a significant role in the economic development of the state of West Virginia. The university's investment in research, faculty and students create a positive impact on the local economic development indicators analyzed in this research. The spillover effect is significant with the support of local and federal government grants when used for research, infrastructure development and community outreach programs. Furthermore, the local and federal government must encourage and stimulate greater collaborations between university and the local industry for sustainable economic development.

\subsection{Hypotheses}

The study attempts to test if West Virginia University has an impact upon the economic development of the state of West Virginia. The impact of West Virginia University in the economic 
development of the state of West Virginia is measured by considering the following economic indicators:

1. Income per Capita

2. Industrial Wages

3. Poverty Rate

4. Public School Enrollment

5. Industrial Earnings

6. Number of Patents

The hypotheses are that the impact of West Virginia University is positive among all the above economic indicators, except for the poverty rate. It is hypothesized that West Virginia University will assist in poverty alleviation.

\subsection{Objectives}

The overall objective of this study is to provide policy makers with information on the role of West Virginia University in the economic development of the state of West Virginia. The specific objectives are:

1. To develop a conceptual multi-agent general equilibrium model and identify a database of socio-economic variable for the state of West Virginia;

2. To identify and empirically estimate the impact of West Virginia University on county level economic development indicators, while controlling for alternative channels of influence;

3. To analyze and interpret the empirical results and make conclusions based on the research findings;

4. To identify the spatial spillover of the impact of West Virginia University on economic development; 
5. To draw policy implications and recommendations for the development of West Virginia based on the empirical results.

\subsection{Area of Study}

The area of study for this research is the state of West Virginia. West Virginia comprises fifty-five counties and fifteen metropolitan statistical areas. The state has forty-three universities and colleges. However, West Virginia University is the primary research university in this state. In addition, there are five universities offering master's degree, fourteen universities offering baccalaureates degree and twenty-one colleges offering associate's degree. Furthermore, the state has two special-focus institutions. Special focus institutions are classified on their concentration on a specific field, for example, engineering, law, medical schools, etc. (Carnegie Classification of Institutions of Higher Education, 2015).

There is another university namely, Marshall University, in West Virginia that offers graduate degree programs. The Carnegie Classifications of Institutions of Higher Education has classified Marshall University under master's colleges and universities and have rated their graduate instructional program as research doctoral in humanities/social sciences dominant fields. However, the Carnegie Classifications of Institutions of Higher Education has classified West Virginia University under doctoral universities with highest research activity and have rated West Virginia University's graduate instructional program as research doctoral in humanities/social science dominant fields. On a similar note, for the year 2007, West Virginia University had 1711 STEM graduate students. Whereas, Marshall University had 475 STEM graduate student for the same year. In terms of research activity, West Virginia University incurred $\$ 138,800$ and Marshall University spent $\$ 22,755$ on research and development. Moreover, West Virginia University’s headcount of research and development personnel was 3,254 and 589 for Marshall University for 
the year 2007. In terms of doctoral degrees, West Virginia University had 143 earned doctorates in the year 2007 whereas Marshall University had only 17 earned doctorates for the same year.

Therefore, West Virginia University's influence on research and development in West Virginia is considerably higher when compared with Marshall University. Moreover, in the absence of availability of detailed data from Marshall University to match with the data available from West Virginia University, this dissertation limits its analysis to studying the impact of West Virginia University in the economic development of the state of West Virginia. However, in the empirical model, the effects of Marshall university on the six economic development indicators are captured by the university indicator. The university indicator also includes the other universities in the state of West Virginia. With the availability of detailed data pertaining to Marshall University, this research may be extended to identify the role of Marshall University and its interactive effect with West Virginia University on the economic development of West Virginia.

According to the West Virginia Department of Commerce, the leading industries in West Virginia include energy, automotive, aerospace, biotech and chemical. Furthermore, West Virginia is home to well-known global companies like Amazon and Lockheed Martin. In the energy sector, West Virginia is one of the primary regions of coal mining in the United States, producing onetenth of the quantity of coal in US, making it the top interstate exporter of electricity in the country.

The automotive industry comprises of large manufacturing companies like Toyota Motor Manufacturing, Diamond Electric etc., employing more than 10,000 workers in the state. Furthermore, the National Research Center for Alternative Fuels, Engines and Emissions is located at West Virginia University. The aerospace industry comprising of companies like Pratt and Whitney, is one of the fastest growing industry in West Virginia. It is due to the presence of a 
substantial number of experienced and skilled workers along with availability of necessary raw materials like metal that keeps the cost to a minimal.

The chemical industry covers 140 chemical related companies providing employment to 13,000 people in the state. Similarly, in the Bio-tech industry, West Virginia is home to one of the largest pharmaceutical manufacturers, Mylan Pharmaceuticals. Therefore, based on the industrial structure, West Virginia can be considered as a science, technology, engineering and mathematics (STEM) oriented state.

\subsection{Organization of the Study}

This study comprises of six chapters. Chapter 2 provides a review of past literature explaining the effect of university spillovers on local economic development. Chapter 3 presents the theoretical model depicting the university's goals and activities and its subsequent influence on the local economy through its activities. Chapter 4 includes the empirical section containing the non-spatial and spatial model estimations. Chapter 5 comprises of the empirical results and their interpretations. Lastly, Chapter 6 summarizes the conclusion, policy recommendations and the scope for future research.

\section{Chapter 2. LITERATURE REVIEW}

\subsection{Introduction}

Romer (1990) states that one of the major determinants of economic growth is the stock of human capital in the economy and the human capital stock devoted to research is inadequate. Therefore, for an economy to experience economic growth, it must have a large stock of human 
capital present in the economy. University is one of the few institutions that produces and fosters human capital that eventually results in the growth and development of an economy.

Several studies have attempted to provide critical insights into the impact of universities on local area development. They have indicated that university has a positive impact on local area innovation, research and development, labor productivity, high-tech industry clustering, besides spatial spillovers to surrounding areas. The literature that highlights this multidimensional role of university is varied and requires separate acknowledgement in this section. Accordingly, the role of university is broadly classified into its impact on research and development, industrial clustering, wages, employment and productivity. Some of the literature that highlights the role of university is discussed below.

\subsection{University Spillover on Industry Research and Development}

Jaffe (1989) in his seminal work measures university spillover effects on industry research and development and concludes that corporate patent has a positive relationship with commercial spillovers from university research. Acs et al. (1992) further extend this study and find that a university's spatial spillover is larger in the case of innovation activity when compared to patent activity. Furthermore, Cohen et al. (2002) point out the crucial mechanisms - namely, academic publications, public conferences and consultancies, through which university research influences industrial research and development.

Similarly, Anselin et al. (1997) using Griliches-Jaffe knowledge production function and geographic coincidence indicator, find a positive and significant statistical relationship between university research and innovations in industry. The paper finds evidence of positive spillovers of university research on industry innovation within 50 miles from the Metropolitan Statistical Area 
(MSA). The authors suggest that university is endogenous to private research and not vice versa. Thus, implying that the industry has a significant influence on university's research and development decisions.

Anselin (2000) extends the previous study of 1997 by applying spatial econometric techniques using industry wise disaggregated data. He re-estimate the Griliches-Jaffe knowledge production function and find significant university research spillover for Electronics and Instruments industries within 75-mile range from the center of the MSA. However, Drugs and Chemicals, and Machinery sectors did not experience similar university spillovers.

Fischer and Varga (2003) note the significance of geography related knowledge spillovers from university research and innovation activities that result in production of knowledge in highly technological firms and industries in Austria. They use spatial econometrics to estimate these effects and find the existence of university-induced knowledge spillovers over the region and these effects decline over space.

In comparable studies, Woodward et al. (2006) and Andersson et al. (2009) find evidence of positive spillover of university research and development expenditure in the form of increase in local patents. Hence, it can be concluded that university spillovers greatly enhance industrial research and development that eventually leads to patent creation and innovation in the local area.

Most of the spillovers that are described above happen in close proximity to colleges/universities and/or MSAs. Audretsch and Stephan (1996) indicates that universities usually collaborate with local industries or industries belonging in the same state. Since it is easier to collaborate within the same state as the legal structure and industrial regulations favor those collaborations. Concurrently, one of the major goals of WVU is the economic development of West Virginia and to collaborate with local industries in the state of West Virginia. The location 
of these industries may be in counties closer to the county where the university is located or further away from the university county. Nevertheless, knowledge spillover is not restricted around the physical location of the industry or the distance between the university and the industry. In the modern technological environment with development of infrastructure and channels of hi-tech telecommunication spillover is not restricted to close proximate local areas but it has a very broad outreach. Therefore, in this context university being a public good for the state its spillover is not restricted to a close proximate area but is felt all over the state. Moreover, WVU being the primary research university in West Virginia its knowledge spillover is expected to be felt by the entire state.

\subsection{University Spillover on Firm Startups}

Bania et al. (1993), using a Poisson Probabilistic Model capturing the probability of a new business starting up in an industry, find evidence of impact of university research on firm startups. After controlling for metropolitan statistical area and other economic characteristics, they discover new firm startups increased significantly for high technology industries after the commercialization of university research. The impact of university research spillover on new business startups were captured for 19 high technology Electrical and Electronic industries.

Likewise, Woodward et al. (2006) find positive knowledge spillover from the local university research and development expenditure. The knowledge spillovers stimulated higher profit maximizing capabilities of firms inducing new high tech startups in counties. However, knowledge spillovers on firm performance is not influenced by the institutional nature of the university, that is, if it is a technical or a general university (Audretsch and Lehmann, 2005). 
Hausman (2012) examines the impact of the Bayh-Dole Act of 1980 that grants universities the property right to the innovations that are created by them using federal funding. Before the inception of this Act the federal government was the owner of the property rights. The passing of the Bayh-Dole Act turned out to be a strong incentive for universities to commercialize research, and collaborate further with the private business enterprises, thus inducing innovation. The paper finds that after the Act was passed, new firms entering the market that were in close proximity to universities experienced exceptional growth over a long time period.

\subsection{University Spillover on Industry Wages}

Rosenthal and Strange (2008) note that proximity to college educated workers improve wages, and nearness to less than college educated workers has a negative effect on wages. This spillover effect happens to attenuate sharply with distance.

In a similar study, Liu (2014) finds workers in high-tech fields enhances the productivity of workers in other low to non-tech fields. Additionally, these high-tech workers benefit more from being in close proximity to workers from similar fields than from the workers in low-tech fields.

Hausman (2012), using a difference-in-differences approach, finds an increase in long-term employment and payroll per worker and this increase is more prominent in the areas situated in close proximity to the university. Furthermore, the study finds that the positive effect on wages diminishes as the distance from the university increases. Hence, exemplifying the significance of university spillover on industrial wages.

\subsection{University Spillover on Industrial Clustering}

Another body of literature concentrates on the role of university spillover on industrial clustering. Audretsch et al. (1996) points out that industries that value knowledge spillovers in 
terms of industrial research and development, university research activity and skilled labor, have a greater predisposition to cluster around universities than industries where knowledge externalities are less significant.

Inzelt (2004) presents Hungarian case studies to highlight the role of government in establishing collaborative partnerships between university and industry. The author undertook four pilot studies to assess the impact of government programs that intended to promote greater linkage between university research and private business operations. Based on the case studies, the author concludes that universities tend to engage more in productive innovations and research if there is a demand for those in local industries. Local businesses involved in research and development and innovative projects closely monitor the progress of doctoral dissertations of students in the universities that match with their areas of expertise. These initiatives bring about greater integration between universities and private business enterprises. Such collaborations and interactions are often found to result in the students being employed in those private firms.

\subsection{University Spillover on Industrial Employment}

Florida and Cohen (1999) examine the impact of university on local area employment. The paper states that university is a system that constantly produces new talents. Fresh students, professors and researchers enter and exit the university system and thereby spill over knowledge to local areas. These knowledge spillovers result in an increase in the supply of skilled workers in the local area leading to an increase in employment, if local demand for skilled workers exists.

Sohn and Kenney (2007) claim that a strong relationship between university and industry results in higher regional development in the presence of proactive government policy. Korean university's focus on entrepreneurial development programs in close liaison with local industries initiated the development of high technology clusters. Moreover, they find that universities provide 
training to a large number of research scientists and engineers that induces greater local area development by raising the local standard of living as well as employment in the area.

Varga (2000) using the Griliches-Jaffe knowledge production function, finds that the concentration of high technology employment is the most critical factor that promotes knowledge transfers from universities. That is, a minimum level of agglomeration is needed in the metropolitan statistical area to generate a significant impact on academic research spending which will in turn have a positive impact on the local economy. Furthermore, local academic knowledge transfers from universities have a positive and significant impact on business sector employment in a metropolitan statistical area.

\subsection{University Spillover on Industrial Productivity}

Moretti (2004) identifies the role of university in enhancing local area's labor productivity. The study states that increases in the share of college graduates in local industries translate into greater industrial productivity. Precisely, the gain in productivity is more than the increase in participation of college graduates. Furthermore, university spillovers from college graduates are more significant in the metropolitan statistical areas.

In a similar study, Kantor and Whalley (2009) examines the impact of university's research activity spillovers on productivity gains to the firms located in urban counties. They find that the university spillovers have a positive impact on a firm's productivity. Moreover, they find the spillovers are greater for technologically intensive firms that are located in close proximity to a research-intensive university.

Similarly, Aghion et al. (2009) find evidence of growth in productivity due to investment in education. They find exogenous shocks in the form of investment in four-year college education 
that are close to technological frontier states result in higher productivity in the local area. However, a similar impact is not seen for a two-year college education.

Andersson et al. (2009) test the impact of decentralization of post-secondary universities in Sweden. The study finds that increasing the previous number of 6 universities to 36 universities and colleges through decentralization over 26 locations, increases productivity and innovations in the local areas. The establishment and expansion of university in an area improves output per worker in the local region.

\subsection{University Spillover on Local Amenities}

Other than the previously stated impact of university on development parameters, a study by Vandegrift et al. (2009) suggest that universities also provide amenities to local surrounding areas that result in an increase in house prices and the tax base of the local economy. Their research shows that house prices are $11 \%$ higher in the vicinity of a college and $14 \%$ stronger for four-year colleges. However, this effect attenuates as the size of the college increases - that is, if the enrollment increases and exceeds 12,500 students.

Evidently from the above-mentioned existing literature, a holistic approach to studying universities impact as an institution in terms of its expenditures, demand for goods and services and supply of skilled labor into the local market remains uncharted. Although a few informal studies have attempted to explicate the impact of universities as an institution over its multitude of services, the need for a theoretical framework and empirical research still subsists (Hoffman and Hill, 2009; Svenson, 2007; Siegfried, 2007 and Leslie and Slaughter, 1992).

Rodrik et al. (2004) estimate the impact of institutions, geography and trade in determining income level around the world and finds that the role and quality of institutions has the largest 
influence on income levels. Hence, once institutions are controlled for, the impact of trade and geography is found insignificant on income levels.

This study identifies the role of university highlighted by various branches of economics such as development, institutional, urban and regional. It not only recognizes the insights provided by the different streams of economics but also attempts to bring together the various mechanisms through which a university impacts local area development through direct and indirect channels. Based on the identified mechanisms from the past literature, the study extends the existing scholarly works by providing a theoretical model. The model formulated recognizes the multidimensional role of a university and its network with local community, industry and government.

Furthermore, this research provides empirical estimation to identify evidence of the role of university in local area development while controlling for other economic factors. Contrary to previous studies, which are mostly conducted at the macroeconomic level, this study captures university spillover at a microeconomic level using county level data. The advantage of this approach lies in identifying the specific university activity that has a positive impact on other economic development indicators like per capita income, poverty and public school enrollment besides knowledge spillovers. These indicators have been ignored in the past literature but they provide a broader role of measuring university spillover on local area development. The econometric model employed in this study has both spatial and non-spatial elements. Moreover, this is the first instance, a system of equation structure has been employed to get efficient estimates and collectively assess the impact of university on all the development indicators being tested in this research. 


\section{Chapter 3. THEORETICAL MODEL}

\subsection{Introduction}

The role of universities on local area development is conceptualized in this section. This research follows Hoffman and Hill (2009) and takes a comprehensive approach in studying the implications of university activities on local area development. Given the availability of data at county level, it is possible to conceptualize a static model capturing interaction across the three important decision making units in a local economy- namely, the university, the local community household and local business, where the latter two units surround the university.

The objective of this research is restricted to assessing the proximate impact of university services on local area development rather than the impact in the reverse direction (i.e., from local area to university) ${ }^{1}$. The general equilibrium model is developed to capture a possible two-way interaction across the above-stated agents. However, in the empirical estimation only one-way causation from the university to local area development is explored. There are mainly three reasons for analyzing only one-way causation from university to local area counties.

First, Jaffe (1989) finds using state level data that there is a significant effect of university research on local business research and development, but no significant effect in the reverse direction. Second, local area of a county within a state being a very small component as compared to a state, the impact of local area activities on university is likely to be of a smaller order. Third, many of the services provided by university have public good characteristics. Neither they are

\footnotetext{
${ }^{1}$ This restrictive assumption is made given lesser evidence of influence from local areas on universities in the existing literature and the absence of available data.
} 
geared to any particular county, nor is it possible to demarcate university services and activities county-wise, as indicated by the available data. Therefore, the university is treated as an exogenous institution that impacts local area households and businesses.

In this context, Hoffman and Hill (2009) argue that university spillovers benefit local area development as universities formulate policies directed towards local area development. These benefits, they argue, accrue even if a university doesn't invest significant resources directly towards local area development. Based on this paper, the following local area development indicators are identified - namely, per capita income, poverty rate, local area employment and its composition (in terms of STEM and non-STEM workers), quality of life parameters (e.g., community households' investments in housing, education and health care), labor productivity, industry research and development expenditure, and industry innovations in terms of patent creation.

The local area development indicators are expressed as results of local household's utility and local business's profit maximizing functions. Additionally, university activities and budgets of local, state and federal governments are treated as exogenously given in the theoretical model. Although West Virginia University is the only research university in the state of West Virginia, the presence of different metropolitan areas in the state, where other smaller universities and colleges do exist, will be suitably controlled in the econometric model. Moreover, a spatial econometric approach will be employed to measure the spatial spillovers of university activities on local area development indicators.

\subsection{University's Optimization Function}

The model capturing university behavior is based on the statement of goals of West Virginia University namely, "to excel in research, creative activity, and innovation in all 
disciplines and to enhance the well-being and the quality of life of the people of West Virginia" (WVU Strategic Planning Council, 2015).

The university as a non-profit entity may be assumed to maximize a welfare or utility function, which includes among its arguments its rank among other universities $(U R A N K)^{2}$, the magnitude of professional publications it produces $(U P U B)$, and the role it plays towards local area development $(U L D E V)$ as highlighted in its mission statement. Mathematically, it can be stated as:

$$
\text { Maximize } W[U R A N K, U P U B, U L D E V]
$$

The arguments are denoted in equation $U 1$ as $i$, where $i=1$ is $U R A N K, i=2$ is $U P U B$ and $i=3$ is $U L D E V$. The first order partial derivatives of $W$ with respect to its arguments are presumed to be negative with respect to $U R A N K\left(W_{1}<0\right)$ and positive for $U P U B\left(W_{2}>0\right)$ and $U L D E V$ $\left(W_{3}>0\right) . U R A N K$ is assumed to be dependent on quality of students admitted - i.e., how stringently the applicants are selected, the faculty-student ratio, and the size of students who have graduated successfully and placed in jobs ${ }^{3}$ (Liu and Cheng, 2005).

It is further assumed that the first partial derivatives of $U R A N K$ with respect to its arguments (represented by $U R A N K_{i}$ ) have the following signs: $U R A N K_{1}<0^{4}, U R A N K_{2}<0$ and $U R A N K_{3}<0$. The model assumes CUAPL and $O U A P L$ as the number of students who apply for admission in a year from the surrounding community and outside, respectively. Also, $\alpha$ is assumed to be the proportion of students accepted $(0<\alpha<1)$ for admission in a year. Therefore, the

\footnotetext{
${ }^{2}$ A university's rank is measured in a way such that lower the numeric value of rank implies higher the university's overall academic rank.

${ }^{3}$ It is assumed for simplicity that students who pass out are all placed in jobs.

${ }^{4}$ URANK $_{1}$ is first partial derivative of URANK with respect to $\alpha$, with (CUAPL+OUAPL) as exogenously given.
} 
number of quality students admitted in a year can be expressed as $\alpha(C U A P L+O U A P L)$. The size of university faculty is denoted by UF and the faculty-student ratio can be expressed as $\frac{U F}{\alpha(C U A P L+O U A P L)}$.

If $\beta$ stands for the proportion of students graduated $(0<\beta<1)$, then the size of successful students graduating out of university per year would be $\beta . \alpha(C U A P L+O U A P L)$. Hence $U R A N K$ can be expressed as

$U R A N K=U R A N K\left[\alpha(C U A P L+O U A P L), \frac{U F}{\alpha(C U A P L+O U A P L)}, \beta \alpha(C U A P L+\right.$ $O U A P L)](U 2)$

University publication rate is assumed to be a function of university research expenditure (URES) per faculty, university capital expenditure per faculty and admitted students ${ }^{5}$, and proportion $\gamma(0<\gamma<1)$ of faculty, who are tenured (Wood, 1990):

$U P U B=U P U B\left[\frac{U R E S}{U F}, \frac{U K E X P}{\{U F+\alpha(C U A P L+O U A P L)\}}, \gamma U F\right]$

It is assumed further that the first partial derivatives of UPUB are all positive, i.e., $U P U B_{i}>0$ for $i=1,2,3$.

It is supposed that $U L D E V$, the local area development indicator entering the university's welfare function is positively related to the following factors: per capita income level of the local community (denoted by $\frac{C Y}{N}$, where $N$ stands for the community size), proportion $\delta(0<\delta<1)$ of

\footnotetext{
${ }^{5}$ This item denotes the extent of infrastructure facilities provided by the university to its faculty and students.
} 
graduated students $\beta . \alpha(C U A P L+O U A P L)$, who are placed in local business, and average business earning per worker in local business (IWORK) (Rosenthal and Strange, 2008; Andersson et al., 2009).

Although university may not have any direct influence over community level poverty indicator $(\mathrm{CPOV})$, and community expenditures on education, medical care and housing (denoted by $C E D U, C M E D$ and $C H U S$, respectively), the university is likely to be concerned about these quality of life parameters and does influence these parameters (Schultz,1961; Sohn and Kenney, 2007).

$$
\begin{aligned}
U L D E V= & U L D E V\left[\frac{C Y}{N}, \delta \cdot \beta \cdot \alpha(C U A P L\right. \\
& + \text { OUAPL),IWORK, } \beta . \alpha . C U A P L, C P O V, C H U S, C M E D]
\end{aligned}
$$

IWORK is assumed to be positively related to local demand for goods and services, local industry R\&D expenditure (denoted by IRND), and the rate of local industry patenting, IPAT (Hausman, 2012). Industrial patent rate is positively related to industry research and development expenditure, $I R N D$, proportion $\delta(0<\delta<1)$ of $S T E M$ workers $^{6}$ who are successfully produced by the university through its programs and placed in local businesses, and university research expenditure. These factors have a positive spillover effect on industry innovations in terms of patent creation (Moretti, 2004).

The induced demand for local goods and services, which bolsters local business earnings per employment through multiplier effect, arises from community consumption expenditure out of

\footnotetext{
${ }^{6}$ STEM is an acronym for science, technology, engineering and math. STEM workers have at least a college degree and earn higher wages than non-STEM workers (Department of Homeland Security, 2011; Langdon et al., 2011)
} 
wage income. Here $c(0<c<1)$ indicates the proportion of community consumption expenditure and $\theta \cdot U F(1+\eta)+w \cdot \beta \cdot \alpha(C U A P L+O U A P L)$ is the total wage income ${ }^{7}$. Here $\theta(0<\theta<1)$ represents the average salary of university staff and faculty, $w(0<w<1)$ signifies average market wage rate and $\eta(0<\eta<1)$ stands for the hiring rate of faculty and staff in the university. The demand for local goods and services are also driven by expenditure of admitted students and their parents on local goods and services (assumed to be spent exclusively on local goods and services). This expenditure is denoted as e. $\alpha(C U A P L+O U A P L)$, where e stands for this expenditure in average terms. Moreover, fraction of university capital expenditure denoted as $k(0<k<1)$ and fraction of university research expenditure represented as $s(0<$ $s<1$ ) are also spent on local goods and services ${ }^{8}$.

Community expenditures on housing and medical services, CHUS and CMED (assumed to be spent exclusively on local goods and services), ${ }^{9}$ respectively, are also assumed to impact local area development indicator. Thus, ULDEV may be defined in full as:

$$
\begin{aligned}
& U L D E V=U L D E V\left[\frac{C Y}{N}, \delta \cdot \beta \cdot \alpha(C U A P L+\text { OUAPL }), I W O R K[c\{\theta \cdot U F(1+\eta)+\right. \\
& \text { w. } . \beta . \alpha(C U A P L+O U A P L)\}+ \text { e. } \alpha(C U A P L+\text { OUAPL })+k \cdot U K E X P+s . U R E S+ \\
& \text { CHUS + CMED,IRND,IPAT(IRND, } \delta \cdot \beta \cdot \alpha(C U A P L+\text { OUAPL }), U R E S)],
\end{aligned}
$$

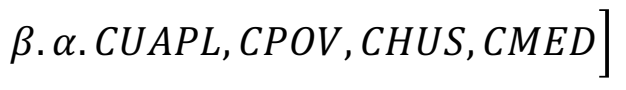

\footnotetext{
${ }^{7}$ It is assumed that all university faculty and staff, irrespective of where they are drawn from, become a part of the community and they spend their entire salary and other earnings from university on local area goods and services either as consumption or as investment in education, housing and medical care.

${ }^{8}$ Fractions 1-k and 1-s are assumed to be spent on goods and services of the outer community.

${ }^{9}$ Community expenditure on education, f. $\alpha$.CUAPL (where $\mathrm{f}$ is fixed fee per admitted student) is assumed to be spent exclusively on this university's education services.
} 
The first partial derivatives of $U L D E V$ with respect to its arguments are assumed to be positive - i.e., $U L D E V_{i}>0$ for $i=1,2,3,4,5,7,8$ and $U L D E V_{i}<0$ for $i=6$. It is further assumed that the first partial derivatives of IWORK and IPAT with respective to their relevant arguments are positive, i.e., $I W O R K_{i}>0$ for $i=1,2,3,4$ and $I P A T_{i}>0$ for $i=1,2,3$.

It is assumed that the total number of successful students is converted into STEM and nonSTEM workers in the proportion of $1: \lambda$ for simplicity purposes. Therefore,

$\beta \alpha(C U A P L+O U A P L)=\operatorname{STEM}(1+\lambda) \quad(U 5)$

It means that by virtue of earlier assumption, $\delta . \operatorname{STE} M(1+\lambda)$ number of students who have graduated are placed by university to work in local businesses. It may be noted that the number of fresh workers appointed in local businesses, $\delta . \operatorname{STEM}(1+\lambda)$ is equal to the number of local community students who were successfully admitted into and graduated out from the university $(\delta . \beta . \alpha C U A P L)$. If there is a difference between these two measures, then the local community may have a net inflow or outflow of trained human capital.

Using equations $U 2-U 5, U 1$ can be re-written as

$$
\begin{aligned}
& \text { Maximize } W=W\left[U R A N K \left\{\alpha(C U A P L+\text { OUAPL }), \frac{U F}{\alpha(C U A P L+O U A P L)}, \beta \alpha(C U A P L+\right.\right. \\
& \text { OUAPL })\}, U P U B\left\{\frac{U R E S}{U F}, \frac{U K E X P}{\{U F+\alpha(C U A P L+O U A P L)\}}, \gamma U F\right\}, U L D E V\left\{\frac{C Y}{N}, \delta \beta \alpha(C U A P L+\right. \\
& \text { OUAPL), IWORK }[c\{\theta \cdot U F(1+\eta)+w \cdot \delta \cdot \beta \cdot \alpha(C U A P L+O U A P L)\}+e \cdot \alpha(C U A P L+ \\
& O U A P L)+k \cdot U K E X P+s \cdot U R E S+C H U S+ \\
& \text { CMED],IRND, IPAT\{(IRND, } . \beta . \alpha(C U A P L+ \\
& \text { OUAPL), URES\}, } \beta . \alpha C U A P L, C P O V, C H U S, C M E D\}]
\end{aligned}
$$


$=W\left[U R A N K\left\{\frac{\operatorname{STEM}(1+\lambda)}{\beta}, \beta \cdot \frac{U F}{\operatorname{STEM}(1+\lambda)}, \operatorname{STEM}(1+\lambda)\right\}, U P U B\left\{\frac{U R E S}{U F}, \frac{U K E X P}{\left[U F+\frac{\operatorname{STEM}(1+\lambda)}{\beta}\right]}, \gamma \cdot U F\right\}\right.$, $\operatorname{ULDEV}\left\{\frac{C Y}{N}, \delta . S T E M(1+\lambda), \operatorname{IWORK}[c\{\theta \cdot \operatorname{UF}(1+\eta)+w \cdot \delta \cdot \operatorname{STEM}(1+\lambda)\}+\right.$ $e . \frac{\operatorname{STEM}(1+\lambda)}{\beta}+k . U K E X P+$ s.URES + CHUS + CMED,IRND,IPAT IRND, $\delta . S T E M(1+$

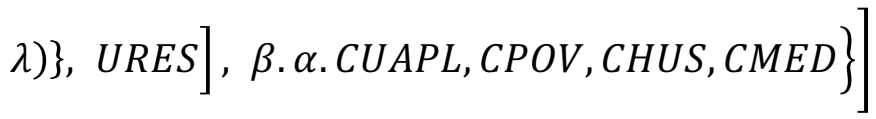

The university is assumed to be always fulfilling its budget constraint such that Costs Revenue $=$ Pre-fixed budgetary support from the state government (say, $\Omega$ ), i.e.,

$$
\begin{aligned}
& U R E X P+U K E X P+U R E S-f . \alpha(C U A P L+O U A P L)-U G R A N T=\Omega, \text { i.e. }, \\
& U R E X P+U K E X P+U R E S-f . \frac{\operatorname{STEM}(1+\lambda)}{\beta}-U G R A N T=\Omega, i . e ., \\
& U K E X P=\Omega-\theta \cdot U F(1+\eta)-U R E S+f \cdot \frac{\operatorname{STEM}(1+\lambda)}{\beta}+U G R A N T
\end{aligned}
$$

UREXP, UKEXP, URES are respectively university's all the recurring expenditure, its capital expenditure and research expenditure. ' $f$ ' stands for fee per admitted student and UGRANT stands for all types of grants received by the university from both government and private sources, revenue from sale of extension and consultancy services etc. Additionally, it is presumed that these sources of funding to be exogenously given.

In this setup involving university, local households and businesses and their strategic independencies, the university's optimization problem may be formulated as maximization of $W$ subject to $U 6$. The local community endogenously decides CUAPL, CHUS and CMED. IRND is 
endogenously chosen by local businesses given the system's exogenous parameters $-\alpha, \beta, \gamma, \delta$, $\theta, \eta, w$ (prevailing average market wage rate of a worker), $k, s, c, \lambda, \Omega, O U A P L, C P O V, U G R A N T$.

This constrained optimization problem solves for the optimum values of URES, UF and STEM (may be denoted by STEM ${ }^{\mathrm{s}}$ ) by solving the first-order conditions for maximization of $W$ with respect to these three variables. Equation $U 6$ determines the optimal value of UKEXP. In this setup, a number of variables are taken as exogenous to reduce the complexity and highlight the interactive decision-making process by the three major agents in a static general equilibrium model. This feature of interdependence in the decision-making process is implicit in Hoffman and Hill (2009), which forms the foundation of the current research. Similarly, the university activities are treated as exogenous in the econometric model for estimation purposes.

\subsection{Industry's Optimization Function}

Next, the optimizing problem for local businesses is formulated. It is assumed that the sole objective of local businesses is to maximize profit - that is, total revenue minus total cost. Since gross revenue per worker data is available across businesses at the county level, it is defined as, IGR (Industry Gross Revenue) $=$ IWORK (Average Gross Earning per Worker)*Total employment of STEM \& Non-STEM workers

Precisely, IGR = IWORK [demand for local goods and services as produced by local business, local industry research and development expenditure (denoted by IRND), and the rate of local industry patenting (denoted as IPAT) ]*Total employment of STEM and non-STEM workers. In terms of notations, 


$$
\begin{aligned}
& I G R=\operatorname{IWORK}\left[c\left\{\theta \cdot U F(1+\eta)+w . \delta . S T E M^{d}(1+\lambda)\right\}+e \cdot \frac{\operatorname{STEM}^{d}(1+\lambda)}{\beta}+k . U K E X P+\right. \\
& \text { s.URES + CHUS + CMED,IRND,IPAT\{IRND, } \left.\left.. S T E M^{d}(1+\lambda), U R E S\right\}\right] * \operatorname{STEM}^{d}(1+
\end{aligned}
$$

It may be noted that the supply of STEM labor (arising from university) is different from its demand (arising from local business), Therefore, to maintain a clear demarcation between the two expressions, supply of STEM labor is denoted by STEM ${ }^{\mathrm{s}}$ and demand of STEM labor is represented by STEM ${ }^{\mathrm{d}}$ (where demand may not match with supply, assuming a competitive labor market). It is assumed that STEM and non-STEM labor are produced as well as demanded in fixed proportion of $1: \lambda$.

Hence, local business profit equation can be written as

$$
\begin{aligned}
& \Pi=\operatorname{IWORK}\left[c\left\{\theta \cdot U F(1+\eta)+w \cdot \delta \cdot S T E M^{d}(1+\lambda)\right\}+e \cdot \frac{S T E M^{d}(1+\lambda)}{\beta}+k \cdot U K E X P\right. \\
& \left.+ \text { s.URES + CHUS + CMED, IRND, IPAT }\left\{I R N D, \delta . S T E M^{d}(1+\lambda), U R E S\right\}\right] \\
& * \\
& \operatorname{STEM}^{d}(1+\lambda)-w \cdot \operatorname{STEM}^{d}(1+\lambda)-\operatorname{IRND}
\end{aligned}
$$

In equation (B2), UF, URES, and UKEXP enter from the university side, as the university chooses their optimal values. The community decides the optimal values of $C H U S$, and $C M E D . c$, $\theta, \eta, w, \delta, \lambda, e, \beta, k$, and $s$ are assumed as exogenous parameters in the model. Assuming no industry budget constraint (i.e., infinitely elastic credit supply at zero interest rate), local business 
will be engaged in optimizing (B2) with respect to $S T E M^{d}$ and IRND. The two first-order optimizations will solve for the optimal values of these two variables as functions of the rest ${ }^{10}$. Once the optimum values of IRND and $S T E M^{d}$ are decided by business for the given optimal value of URES from the university side. The creation of new patents is decided by the following equation:

$I P A T=I P A T\left[I R N D, \operatorname{STEM}^{d}(1+\lambda), U R E S\right]$

\subsection{Community's Optimization Function}

Finally, the optimization problem of a typical local community household is formulated. It is assumed that the households engage in utility maximization subject to full employment and income-expenditure balance conditions. It is assumed that the community has a total population size ' $N$ ' inclusive of faculty and staff engaged in university. Thus, the community household's optimization problem can be formulated as:

Maximize $U$ [c. CY, CEDU, CHUS, CMED],

subject to

$U F(1+\eta)+\operatorname{STEM}^{d}(1+\lambda)+\alpha \cdot C U A P L=N=>C U A P L=$

$\frac{\left[N-\left\{U F(1+\eta)+\operatorname{STEM}^{d}(1+\lambda)\right\}\right]}{\alpha}$,

\footnotetext{
${ }^{10}$ Fulfillment of appropriate regularity conditions is assumed to satisfy second order conditions for each optimization problem.
} 
and

$$
\begin{aligned}
& \text { c. } C Y+C E D U+C H U S+C M E D=C Y, \text { i.e. }, C E D U+C H U S+C M E D \\
& =(1-c) . C Y, i . e ., \\
& \text { CHUS }=(1-c)\left\{\theta \cdot U F(1+\eta)+w \cdot S T E M^{d}(1+\lambda)\right\}-f \cdot\left[N-\left\{U F(1+\eta)+S T E M^{d}(1\right.\right. \\
& +\lambda)\}]-C M E D
\end{aligned}
$$

As mentioned earlier, the fraction $c(0<c<1)$, which is exogenously given, stands for fixed average propensity to consume. Employment consists of university staff and faculty, employment of STEM and non-STEM workers by local business, and students admitted into university for higher education. It is presumed that all first and second partial derivatives of $U$ are obeying the regularity conditions of a concave utility function, so that $U_{i}>0$ and $U_{i i}<0$ for $i=$ $1,2,3,4$. Using the last two equations $C 2-C 3$, the representative community household's optimization problem can be re-written as:

$$
\begin{aligned}
\text { Maximize } U[\text { c. }\{\theta \cdot U F(1+\eta) & \\
& \left.+w \cdot S T E M^{d}(1+\lambda)\right\}, f \cdot \frac{\left[N-\left\{U F(1+\eta)+S T E M^{d}(1+\lambda)\right\}\right]}{\alpha},[(1 \\
& -c)\left\{\theta \cdot U F(1+\eta)+w \cdot \operatorname{STEM}^{d}(1+\lambda)\right\} \\
& \left.\left.-f .\left[N-\left\{U F(1+\eta)+\operatorname{STEM}^{d}(1+\lambda)\right\}\right]-C M E D\right], C M E D\right],
\end{aligned}
$$

The above expression is optimized with respect to only $C M E D$. The first-order condition for optimization provides the optimal value of $C M E D$. Equations $C 2-C 3$ will provide the optimal values of $C U A P L$ and $C H U S$, given the optimum values of $U F$ of $S T E M^{d}$ as decided by university 
and local industry, respectively. The other parameters involved in this equation are exogenous by construction.

The above-stated static general equilibrium model captures the essential features of interdependence in decision-making across the three major agents in local area development namely, university, local businesses and local community households over a single time period.

In this model, a representative community household decides on optimum levels of expenditure on housing, medical care and education (i.e., $C H U S^{*}, C M E D^{*}$ and $C E D U^{*}=$ f. $\alpha . C U A P L^{*}$, given $U F^{*}$ and $S T E M^{d *}$ as optimally decided by university and local business, respectively). Local area businesses choose the optimal level of employment and its research and development expenditure - namely, STE $M^{d *}$ and IRND* given $U F^{*}, U R E S^{*}, U K E X P^{*}$ as decided by the university and $C H U S^{*}, C M E D^{*}$ as chosen by the community. The university chooses optimal values of $U R E S^{*}, U F^{*}$ and $S T E M^{S^{*}}$, given optimal values of $C U A P L^{*}, C H U S^{*}$ and $C M E D^{*}$ as decided by the community and IRND* as chosen by local business.

The model recognizes the existence of a broader outside world, which may also benefit from university activities as well as from activities by different levels of government in the county, but the outside world is not explicitly modeled as an endogenous decision-making unit. However, this simplifying assumption has no possible impact on the broad role of a university and its impact on local area development as discussed by Hoffman and Hill (2009).

Additionally, following Beeson and Montgomery (1993), migration is not incorporated into this model as the study finds that the gross migration inflows and outflows from an area are higher in locations where universities have large research and development funding that indicates an active labor market with high turnover rates. The high in and out migration offset each other and the study finds no impact of university research and development funding on net migration. 
Furthermore, this model does not differentiate the physical boundaries of different counties, which surround the university. Instead, it treats all counties as part of a single large

community, wherein the spillover effects of the main university's ${ }^{11}$ activities are determined by geographical factors (Anselin et al., 1997; Anselin, 2000). Therefore, spatial econometric techniques are employed in the empirical section to estimate the spillover effects of a university.

\section{Chapter 4. EMPIRICAL MODEL}

Based on the foundation of the theoretical model specified in the preceding segment, this section empirically tests the impact of West Virginia University on local area development for the counties within the state of West Virginia, using suitable controls as advocated in the literature. There is a strategic interdependence between university and local area as already highlighted in the theoretical model in the preceding section. Hence, it is presumed that the local area development indicators are functions of various exogenous factors including university activities, county, business and government features. The empirical model controls for geographic factors such as location and proximate influences of various metropolitan cities within the state, where other universities (except for West Virginia University) and colleges are located.

Based on the existing literature, available data and the research hypotheses, the study identifies six development indicators to assess the impact of West Virginia University on the

\footnotetext{
${ }^{11}$ In this case it is West Virginia University
} 
economic development of West Virginia. The six endogenous variables are: Income per Capita, Industrial Earning per Industrial Unit, Number of Patents per STEM Industrial Unit, Poverty Rate, Public School Enrollment ${ }^{12}$ per Capita and Total Average Industry Wage. In this section, a set of non-spatial and spatial econometric models are estimated capturing university spillovers on the above mentioned economic indicators.

\subsection{Non-Spatial Models}

The study estimates Least Square Dummy Variable (LSDV) regressions for each of the six dependent variables which are functions of observed university, industry, community, federal, state and local government characteristics. In these estimations time dummies are introduced to control for time trends as university variables are cross-section invariant but time variant.

LSDV is unbiased but inconsistent in a short panel where the time series component is small (Cameron and Trivedi, 2005). Therefore, panel data regression models are estimated for each of the six dependent variables with the same variables used in the LSDV specifications. The Hausman specification test (Hausman, 1978) is employed to choose between fixed effects or a random effects model. Additionally, the F-test is used to check for time-fixed effects when Hausman test suggests a fixed effects model over a random effects model. Moreover, a test for stationarity is performed using Unit Root test since the data has a time series over the period of 2001 to 2007 (Dickey and Fuller, 1979; Greene, 2003).

It is hypothesized that there is cross equation error correlation among all the six estimated equations in the system due to unobserved and common characteristics that are not part of the

\footnotetext{
${ }^{12}$ Public school enrollment refers to enrollment in West Virginia public schools from Pre-Kindergarten to Grade 12.
} 
deterministic component of the model. In such situations, Seemingly Unrelated Regression (SUR) is more efficient compared to the single equation estimates (Zellner, 1962; Rey and Montouri, 1999). Therefore, the Breusch-Pagan test is employed to check the existence of cross equation error correlation (Breusch and Pagan, 1979; Cameron and Trivedi, 2005). Additionally, the Jarque-Bera and Shapiro-Wilk tests are performed to check for normality of the residuals from the estimated regressions (Shapiro and Wilk, 1965; Jarque and Bera, 1980; Cameron and Trivedi, 2005). The test results are reported in the Result Appendix.

The specifications of the regressions are as follows:

\subsubsection{Specification 1: Least Square Dummy Variables}

$$
\begin{gathered}
D E V_{i t}=\alpha+W V U_{t} \beta_{U}+\operatorname{OUNI}_{i} \beta_{O}+\operatorname{INDUS}_{i t} \beta_{B}+\operatorname{COM}_{i t} \beta_{C}+G O V T_{i t} \beta_{G} \\
+\sum_{t=2002}^{2007} \gamma_{t} \operatorname{TIME}_{t}+\varepsilon_{i t}
\end{gathered}
$$

The above stated expression represents a regression where ' $\mathrm{i}$ ' signifies county ' $\mathrm{i}$ ' in West Virginia state, where $i=1,2,3 \ldots, 55$; and ' $t$ ' stands for time. The available database varies over 7 years such that $\mathrm{t}=2001,2002, \ldots, 2007 . D E V_{i t}$ stands for development indicator for county ' $\mathrm{i}$ ' at time ' $\mathrm{t}$ '. $\alpha$ is the intercept in the regression equation. $W V U_{t}$ includes West Virginia University characteristics which vary over ' $t$ ' but not across county ' $i$ ' in this matrix. The presence of other universities (other than West Virginia University) in individual counties are controlled by specifying a dummy variable that takes the value of 1 , if at least one (other than WVU) university/college is present in that county ' $\mathrm{i}$ ' which is within the West Virginia state education system, and 0 otherwise. This variable is included in $O U N I_{i}$ matrix. This matrix also includes two 
additional indicators. First, when the county ' $\mathrm{i}$ ' is located in a metropolitan statistical area (MSA) then the indicator takes the value 1 , and 0 otherwise. Second, when a county ' $i$ ' is located in a MSA and has at least one university/college present then it is coded as 1 and absence is coded as 0.

West Virginia shares its border with Virginia, Maryland, Pennsylvania, Kentucky and Ohio. Some of the geographic areas around these borders have high industrial and economic activities. The US Census Bureau has identified these areas as metropolitan statistical areas (MSA). This study has explicitly identified these pockets of high economic activities and have suitably controlled in the empirical models using dummy variables for the counties that have economic integration with the neighboring states in the form of MSA. The MSA indicator not only includes the MSAs which are within West Virginia but also the MSAs that are formed with counties from neighboring states. This variable in the empirical model captures the state level variations and spillover from the border sharing states. Accounting for every county sharing a border with the neighboring states may not provide a realistic measure for capturing the other states spillover since they may not share common characteristics and consequently may not have an influence on each other. Whereas the MSA indicator realistically captures the common characteristics and integration of economic activities between a county of West Virginia and the neighboring state.

Characteristics of local industries that have an impact on economic development of West Virginia is captured in the INDUS $i t$ matrix. Community level factors are included in the $C O M_{i t}$ matrix. The GOVT $i t$ matrix encompasses other exogenous factors like local, state and federal government budget variables, which are treated as controls in this regression framework. These factors vary over county ' $\mathrm{i}$ ' and over time ' $\mathrm{t}$ '. Detailed description of the variables considered in 
each of the matrices are provided in the Data Appendix. Time fixed effect dummies $\left(\sum_{t=2002}^{2007} \gamma_{t} T I M E_{t}\right)$ are introduced in this specification to control for the effect of time on the dependent variables.

\subsubsection{Specification 2A: Fixed Effects}

$$
\begin{gathered}
D E V_{i t}=\alpha+W V U_{t} \beta_{U}+\operatorname{INDUS}_{i t} \beta_{B}+\operatorname{COM}_{i t} \beta_{C}+\operatorname{GOVT}_{i t} \beta_{G}+\sum_{i=2}^{55} \delta_{i} C S_{i} \\
+\sum_{t=2002}^{2007} \gamma_{t} \operatorname{TIME}_{t}+\varepsilon_{i t}
\end{gathered}
$$

\subsubsection{Specification 2B: Random Effects}

$$
\begin{aligned}
D E V_{i t}=\alpha+ & W V U_{t} \beta_{U}+\operatorname{OUNI}_{i} \beta_{O}+\operatorname{INDUS}_{i t} \beta_{B}+\operatorname{COM}_{i t} \beta_{C}+\text { GOVT }_{i t} \beta_{G}+\delta \\
& +u_{i}+\varepsilon_{i t}
\end{aligned}
$$

Two more specifications (2A) and (2B) are estimated using the panel structure of the data. Specification (1) is used as the baseline and appropriate changes are made based on the requirements of a panel data model to obtain the specifications (2A) and (2B). The variable $O U N I_{i}$ drops out of specification (2A) since time invariant characteristics drop out from a fixed effects model. A fixed effects model is appropriate for analyzing the effect of variables that change over time (Greene, 2003).

In a fixed effects model each cross-sectional unit has its own distinct individual specific characteristics that may or may not affect the dependent variable. Not controlling for these characteristics may result in biased regression coefficients. The cross-sectional fixed effects are 
controlled by specifying 54 dummy variables for 55 counties in the data ${ }^{13}$. Furthermore, time fixed effects are introduced in the regressions to control for omitted variables that vary over time but are constant across the cross-sectional units ${ }^{14}$.

Correspondingly, a random effects model is specified in specification (2B). In a random effects model, the variation across cross-sectional units (in this case counties) are assumed to be random and uncorrelated with the exogenous variables included in the model (Greene, 2003). Therefore, it is assumed that differences in counties affect the dependent variables. Moreover, a random effects specification allows inclusion of variables that are time invariant. This specification allows the variable $O U N I_{i}$ to be part in the estimation equation. However, in a random effects model, individual characteristics may or may not affect the dependent variable but unavailability of certain variables to control for individual characteristics often result into omitted variable bias (Greene, 2003).

The choice between the two models is driven by many considerations. Either the choice is based on theoretical considerations, guidance from contemporary scholarly literature, previous studies on similar subject or is purely an empirical one. The fixed effects model uses dummy variables to control for cross-sectional and time fixed effects ${ }^{15}$. That reduces degrees of freedom substantially in a smaller panel dataset. However, a fixed effects model treats individual effects as uncorrelated with other explanatory variables unlike a random effects model. A random effects model may result in inconsistency if there is correlation among the included explanatory variables and the random effects component (Hausman and Taylor,1981; Chamberlain,1978; Greene, 2003).

\footnotetext{
13 Including dummy variables for all the 55 counties would result in multicollinearity (Greene, 2003)

${ }^{14}$ Additionally, the Dickey-Fuller Test is performed to test for unit root (Dickey and Fuller, 1979). The test fails to reject the hypothesis of no unit root for the panel data. The test results are reported in the Result Appendix.

${ }^{15}$ In this case, time fixed effects are introduced
} 
In the absence of any a priori direction, the Hausman Specification test (Hausman 1978; Greene, 2003) is used to choose between a fixed effects and a random effects model. The null hypothesis of this test states that the random effects model is preferred over fixed effects versus the vice-versa under the alternative hypothesis. This test examines whether errors are correlated with the regressors under the null hypothesis and not under the alternative hypothesis. The test results are reported in the Result Appendix.

\subsubsection{Specification 3: Seemingly Unrelated Regression in Panel Framework}

$$
\begin{gathered}
D E V_{j i t}=\alpha_{j}+W V U_{j t} \beta_{U}+I N D U S_{j i t} \beta_{B}+C O M_{j i t} \beta_{C}+G O V T_{j i t} \beta_{G}+\sum_{\substack{i=2, j=1}}^{\substack{j=6, i=55}} \delta_{i j} C S_{i j} \\
+\sum_{\substack{t=2002, j=1}} \gamma_{j t} T I M E_{j t}+\varepsilon_{j i t}
\end{gathered}
$$

In specification $(3)^{16}, D E V_{j i t}$ signifies the dependent variable of county ' $\mathrm{i}$ ' in period ' $\mathrm{t}$ ' in equation ' $\mathrm{j}$ '. In this case, there are six development indicators as dependent variables. Therefore $j=1,2,3, \ldots, 6$. It is hypothesized that the presence of cross equation error correlation among ' $j$ ' equations in the system are due to unobserved and common characteristics that are not included in the deterministic part of the model. Moreover, cross-sectional component of the error term $\left(\varepsilon_{j i t}\right)$ may be correlated over time. In such situations, Seemingly Unrelated Regression (SUR) is more efficient compared to the single equation estimates obtained by OLS (Zellner, 1962; Rey and Montouri, 1999).

\footnotetext{
${ }^{16}$ The Hausman Specification test is performed for specifications (2A) and (2B) for each of the six development indicators. The test rejects the null hypothesis for all development indicators. Therefore, the specification $(2 \mathrm{~A})$ is estimated. The fixed effects panel SUR model is estimated using the (2A) specification.
} 
The SUR estimates for the parameters $\beta_{U}, \beta_{B}, \beta_{C}, \beta_{G}, \delta_{i j}, \gamma_{j t}$ will be obtained using Feasible Generalized Least Squares (FGLS) estimator. The Breusch-Pagan test of independent errors is employed to check for cross-equation error correlation. The null hypothesis is presence of no cross-equation error correlation while the alternative hypothesis is of presence of contemporaneous correlation (Breusch and Pagan, 1979). The test confirms the presence of crossequation error correlation in the system of equations ${ }^{17}$.

\subsection{Spatial Models}

The non-spatial model specifications mentioned above do not take into account spatial spillovers from one location to another. According to Anselin (1988) ignoring spatial heterogeneity and omitted spatial lags of a dependent variable results in biased and inconsistent estimates.

Moreover, similar studies examining university impacts have found positive spatial spillovers in terms of industry innovation, patents, demand for skilled labor, increased labor productivity, higher wages and so forth. This results in industrial clustering and the formation of technological corridors around universities (Rosenthal and Strange, 2008; Fischer and Varga, 2003; Varga, 2000; Moretti, 2004; Kantor and Whalley, 2009).

Furthermore, the data for this study involves 55 counties from the state of West Virginia spanning over a period of 7 years. Hence, given proximity of counties and sharing of geographical boundaries among each other, it is hypothesized that there is a presence of spatial spillover effect. The first step in examining this hypothesis involves testing for spatial autocorrelation using Moran's I statistics (Moran, 1950).

\footnotetext{
${ }^{17}$ The results are reported in the Result Appendix.
} 
The statistics takes a value from -1 to +1 . Positive values indicate positive spatial spillovers and negative spillovers are indicated by negative values. A random spatial pattern is suggested by this statistic when it takes a value equal to zero. It is possible to test hypothesis by converting the statistics into Z-scores. The Moran's I test performed for this study confirms the presence of positive spatial spillovers and therefore this analysis uses the panel nature of the data to estimate spatial panel models. The results are reported in the Result Appendix.

The next step is the selection of an appropriate spatial model for analysis from the following models:

1. Ordinary Least Square (OLS): $y=\alpha+X \beta+\varepsilon$

2. Spatial Autoregressive Model (SAR): $y=\alpha+\rho W y+X \beta+\varepsilon$

3. Spatial Error Model (SEM): $y=\alpha+X \beta+\varepsilon$ where $\varepsilon=\lambda W \varepsilon+v$

4. Spatial Lag of X Model (SLX): $y=\alpha+X \beta+W X \theta+\varepsilon$

5. Spatial Durbin Model (SDM): $y=\alpha+\rho W y+X \beta+W X \theta+\varepsilon$

Elhorst's (2010) testing procedure is used to identify the type of spatial dependence present in the data. First, the Ordinary Least Square (OLS) model is estimated to check if the spatial lag or error model is more suitable for the data being used for analysis.

The standard Lagrange Multiplier (LM) test proposed by Anselin (1988) for panel data is used to perform both the LM lag test in order to examine the hypothesis of no spatial lag in the dependent variable (Spatial Autoregressive Model) and LM error test to check the hypothesis of no spatial autocorrelation in the error term (Spatial Error Model). Both the standard LM tests (LM lag and LM error) reject the null hypothesis of no spatial dependence in the OLS model, signifying the presence of spatial lag in the dependent variable and/or spatial correlation in the error term. 
The LM tests use the estimation of OLS residuals and the weight matrix to check for spatial dependence (Elhorst, 2010). However, the standard LM test has an influence over the spatial autocorrelation of the other. That is, it ignores the existence of the other form of spatial correlation. But, the Robust LM test considers such potential misspecifications in its analysis. Hence, the Robust Lagrange Multiplier test proposed by Anselin et al. (1996) is performed.

Following Elhorst's (2010) procedure, the Spatial Durbin Model (SDM) is estimated, which is a generalization of the OLS, SAR and SEM models and the Likelihood Ratio (LR) test is performed to check the hypotheses: $H_{0}: \theta=0$ and $H_{0}: \theta+\rho \beta=0$. The first hypothesis assesses if the SDM model can be reduced to the SAR model by removing the spatial component from the independent variable. And the second hypothesis examines if the SDM can be simplified to the SEM model by removing spatial lags from both the dependent and independent variables. If both the hypotheses are rejected, then the SDM is the appropriate model.

Accordingly, if the hypothesis $H_{0}: \theta=0$ cannot be rejected, then the spatial lag model (SAR) is more appropriate considering if the robust LM test point to a SAR model. Similarly, if the hypothesis $H_{0}: \theta+\rho \beta=0$ cannot be rejected, then the Spatial Error Model (SEM) is more appropriate provided the Robust LM test points to employing SEM. If both the LR and robust LM tests do not conform and point to different models, then the Spatial Durbin Model is employed.

If SDM is selected as the most favorable model for the data, then the rho $(\rho)$ parameter in the SDM needs to be tested for being statistically different from zero. This is because SDM consists of a lag dependent variable in its framework. Additionally, the hypothesis, $H_{0}: \theta=0$ must be verified using the Wald test since SDM also includes spatially weighted $(\theta)$ independent variables in its structure similar to a SLX model. 
If the null hypotheses, $H_{0}: \rho \neq 0$ and $H_{0}: \theta=0$ cannot be rejected then the SDM framework must be employed since there is a presence of spatial dependence in the data and SDM is an unrestrictive general model when compared to other spatial models that account for more specific forms of spillovers. Additionally, if the null hypotheses, $H_{0}: \rho \neq 0$ and $H_{0}: \theta=0$ are rejected, implying no spatially lagged dependent variables but the presence of spatially weighted independent variable, the SLX model becomes the most favorable structure in such a case.

In this analysis, following the test procedures stated above, the Spatial Durbin Model is found to be the most favorable model for analyzing each of the six economic development indicators. The Spatial Durbin Model (SDM) is a global model and according to Elhorst (2010) only the SDM produces unbiased coefficient estimates irrespective of the true data generating process following a spatial lag (SAR), spatial error (SEM), Kelejian-Prucha or a Spatial Durbin Error (SDEM) structure. Hence, the Spatial Durbin Panel Model is employed for further analysis.

\subsubsection{Specification 4: Spatial Panel Durbin Model}

$$
\begin{aligned}
D E V_{i t}=\alpha+ & \rho\left(I_{T} \otimes W_{n}\right) D E V_{i t}+\left(W V U_{j t} \beta_{U}+I N D U S_{i t} \beta_{B}+\operatorname{COM}_{i t} \beta_{C}+G O V T_{i t} \beta_{G}\right) \\
& +\left(I_{T} \otimes W_{n}\right)\left(W V U_{j t} \beta_{U}+I N D U S_{i t} \beta_{B}+C O M_{i t} \beta_{C}\right. \\
& \left.+G O V T_{i t} \beta_{G}\right) \theta+\sum_{t=2002}^{2007} \gamma_{t} T_{I M E_{t}}+\varepsilon_{i}
\end{aligned}
$$

where $\varepsilon_{i}=\left(i_{t} \otimes I_{n}\right) \mu+u$ 
Following Elhorst (2003) and Millo and Piras (2012), the fixed effects Spatial Durbin Model is specified ${ }^{18}$. This specification controls for auto correlated error term and spatial fixed effects. In this specification, $W_{n}$ is a non-stochastic spatial weight matrix ${ }^{19}$. The term $\left(i_{t} \otimes I_{n}\right) \mu$ controls for both time and cross-sectional fixed effects which are part of the error term $\varepsilon_{i}$ in (4A). In (4), $\rho$ and $\theta$ are the spatially lagged dependent and independent parameters, bounded between -1 and +1 . Equation (4) is estimated for each of the six development indicators using Maximum Likelihood estimation technique. Additionally, time fixed effects are controlled by introducing time dummies in specification (4).

According to LeSage and Pace (2010), the results obtained from SDM are separated into five categorizes, namely, coefficient estimates, direct effects, feedback effects, indirect effects and total effects. Since, SDM includes the spatially lagged dependent variable in its framework, the direct effect obtained from the regression includes the feedback effect. Feedback effect is the result of impacts passing through neighboring regions and back to the region itself which can be captured by taking the difference between direct effects and the coefficient estimates. If the difference is positive, then the feedbacks are positive and vice versa. The direct effects capture the impact of change of an independent variable in a specific unit (county) on the dependent variable of that unit (county). However, the indirect effects capture the impact of a change in the independent variable in a specific unit (county) on the dependent variable of other counties. These broad definitions are used to interpret the regression estimates in the result section.

Having tested the model in the Spatial Panel Durbin Fixed Effects framework, the next logical step is to use the six estimated regressions from (4) in a system of equation structure such

\footnotetext{
${ }^{18}$ The Hausman Specification Test (Hausman, 1978) is performed for Spatial Fixed Effects vs. Spatial Random Effects Models for all the six development indicator. The test results suggest using Spatial Fixed Effects Models. The test results are reported in the Result Appendix.

${ }^{19}$ The spatial weight matrix is computed using latitudes and longitudes of the counties of West Virginia
} 
as a Seemingly Unrelated Spatial Panel Regression (SUR) model. Moreover, Anselin et al. (2008) point out that a non-spatial SUR structure specification fails to take into account spatial and intertemporal spatial dependencies and there may be improvements in estimation by using a spatial SUR model. However, implementation of spatial SUR models has been limited to a very few empirical analysis (Baltagi, 2011). Most of the research has been in its theoretical domain with inadequate software support for empirical estimation. Furthermore, the marginal effects computed by some of the software packages have not been verified for their robustness. In the absence of appropriate software support for spatial SUR, the spatial analysis in this study is limited to a Spatial Panel Model as outlined in specification (4).

The results of various test for the specifications (1)-(4) are provided in the Result Appendix. The following section includes a description of the data and the summary statistics of the variables used in the regression models.

\subsection{Data}

The data for this study are a balanced panel of 7 annual observations for 55 counties of West Virginia spanning from 2001 to 2007. A panel of this size provides enough variation for efficient estimation of model parameters. The data is incorporated from a variety of sources such as U.S. Census Bureau, National Science Foundation, U.S. Bureau of Labor Statistics, U.S. Department of Education, U.S. Patent and Trademark Office and West Virginia University's Financial Statements and Institutional Reports. The Data Appendix provides detailed information about the data sources. 
The available variables are classified from these sources into six development indicators (D) which are taken as dependent variables and then into categories of exogenous variables. The exogenous variables are broadly classified into four categories, namely, University (U), Industry (I), Community (C) and Government (G). Additionally, using the raw data, a number of economic variables are constructed in the form of ratios for generating precise indicators of university, industry, community and government characteristics. The ratios constructed are then employed appropriately as dependent and independent variables in the regression. The summary statistics are reported for each regression equation, as follows:

Table 1 Summary Statistics for Income Per capita Model

\begin{tabular}{|l|c|c|c|c|}
\hline \multicolumn{1}{|c|}{ Variable } & Mean & Std. dev. & Min & Max \\
\hline Income per capita in Dollars (D) & $23,262.84$ & $4,292.53$ & 15,009 & 39,337 \\
\hline $\begin{array}{l}\text { West Virginia University (WVU) STEM } \\
\text { R\&D Expenditure per Faculty in Dollars (U) }\end{array}$ & 42,620 & 5,950 & 34,150 & 51,010 \\
\hline $\begin{array}{l}\text { WVU Recurring Expenditure per Tenured } \\
\text { Faculty in Dollars (U) }\end{array}$ & 61,208 & 5,587 & 53,419 & 73,209 \\
\hline $\begin{array}{l}\text { WVU Education Sales and Services per } \\
\text { Graduate Student in Dollars (U) }\end{array}$ & 18,300 & 5,000 & 12,800 & 25,600 \\
\hline Educational Service Representative Units (I) & 14.48 & 17.15 & 0 & 123 \\
\hline Job to Population Ratio (C) & 0.43 & 0.12 & 0.19 & 0.73 \\
\hline Building Permits (C) & 94.2 & 228.11 & 0 & 1,935 \\
\hline $\begin{array}{l}\text { Metropolitan Area and Presence of } \\
\text { University Indicator (C) }\end{array}$ & 0.16 & 0.37 & 0 & 1 \\
\hline $\begin{array}{l}\text { Ratio of Federal Earnings to Federal } \\
\text { Government Employment in Dollars (G) }\end{array}$ & 661.20 & 139 & 3,908 & $1,089.4$ \\
\hline $\begin{array}{l}\text { Local Government Earnings Per Capita in } \\
\text { Dollars (G) }\end{array}$ & $1,843.73$ & 824.06 & $1,026.36$ & $7,303.99$ \\
\hline
\end{tabular}

Source: Author computed 
Table 2 Summary Statistics for Total Average Industry Wage Model

\begin{tabular}{|l|c|c|c|c|}
\hline \multicolumn{1}{|c|}{ Variable } & Mean & Std. dev. & Min & Max \\
\hline Total Average Industry Wage (D) & $28,229.44$ & $4,898.61$ & 18,339 & 46,310 \\
\hline $\begin{array}{l}\text { WVU Educational Sales and Services per } \\
\text { Faculty in Dollars (U) }\end{array}$ & 39,300 & 9,300 & 2,780 & 5,460 \\
\hline $\begin{array}{l}\text { WVU Recurring Expenditure per Tenured } \\
\text { Faculty in Dollars (U) }\end{array}$ & 61,208 & 5,587 & 53,419 & 73,209 \\
\hline WVU STEM Post-Doctoral Students (U) & 11.1 & 4.36 & 8 & 19 \\
\hline STEM Industrial Earnings in Dollars (I) & $266,726.60$ & $458,512.40$ & $10,009.00$ & $3,409,382$ \\
\hline Violent Crimes (C) & 81.63 & 142.04 & 1 & 1,209 \\
\hline $\begin{array}{l}\text { Metropolitan Statistical Area and Presence } \\
\text { of University Indicator (C) }\end{array}$ & 0.16 & 0.37 & 0 & 1 \\
\hline $\begin{array}{l}\text { Ratio of Local Government Earnings to } \\
\text { Local Government Employment in } \\
\text { Dollars(G) }\end{array}$ & 4,157 & 514 & 2,489 & 5,334 \\
\hline
\end{tabular}

Source: Author computed

Table 3 Summary Statistics for Poverty Rate Model

\begin{tabular}{|l|c|c|c|c|}
\hline \multicolumn{1}{|c|}{ Variable } & Mean & Std. dev. & Min & Max \\
\hline Poverty Rate (D) & 17.83 & 4.84 & 8.3 & 38.9 \\
\hline $\begin{array}{l}\text { WVU Non-STEM R\&D Expenditure per } \\
\text { Post Doctorate Student in Dollars (U) }\end{array}$ & 26,819 & 10,502 & 7,837 & 43,962 \\
\hline $\begin{array}{l}\text { Number of STEM Graduate Students in } \\
\text { WVU (U) }\end{array}$ & $1,650.25$ & 50.62 & 1,581 & 1,711 \\
\hline STEM Industrial Earnings in Dollars (I) & $266,726.60$ & $458,512.40$ & $10,009.00$ & $3,409,382$ \\
\hline Metropolitan Statistical Area Indicator (C) & 0.31 & 0.46 & 0 & 1 \\
\hline $\begin{array}{l}\text { Federal Government Employment per } \\
\text { capita (G) }\end{array}$ & 8.16 & 10.38 & 1.47 & 57.45 \\
\hline
\end{tabular}

Source: Author computed 
Table 4 Summary Statistics for Public School Enrollment Per Capita Model

\begin{tabular}{|l|c|c|c|c|}
\hline \multicolumn{1}{|c|}{ Variable } & Mean & Std. dev. & Min & Max \\
\hline Public School Enrollment per capita (D) & 16.13 & 1.79 & 11.13 & 21.43 \\
\hline $\begin{array}{l}\text { WVU Grants per Undergraduate Student in } \\
\text { Dollars (U) }\end{array}$ & 8,990 & 1,590 & 6,990 & 12,300 \\
\hline $\begin{array}{l}\text { WVU Recurring Expenditure per Post } \\
\text { Doctorate Student in Dollars (U) }\end{array}$ & $61,568.10$ & $15,220.53$ & $28,086.95$ & $89,864.13$ \\
\hline $\begin{array}{l}\text { WVU Capital Asset Investment per Doctoral } \\
\text { Students in Dollars (U) }\end{array}$ & $3,376.86$ & $1,033.43$ & $2,431.74$ & $5,663.03$ \\
\hline $\begin{array}{l}\text { Ratio of STEM to NON STEM Jobs in } \\
\text { Industries (I) }\end{array}$ & 1.06 & 0.57 & 0.21 & 4.32 \\
\hline Violent Crimes (C) & 81.63 & 142.04 & 1 & 1,209 \\
\hline $\begin{array}{l}\text { Federal Government Expenditure per } \\
\text { Federal Employment in Dollars (G) }\end{array}$ & $1,882.08$ & $1,141.15$ & 118.96 & $6,019.46$ \\
\hline
\end{tabular}

Source: Author computed

Table 5 Summary Statistics for Industrial Earnings Per Industrial Unit Model

\begin{tabular}{|l|c|c|c|c|}
\hline \multicolumn{1}{|c|}{ Variable } & Mean & Std. dev. & Min & Max \\
\hline Industrial Earnings Per Industrial Unit (D) & 615,770 & 196,100 & 26,050 & $1,288,660$ \\
\hline $\begin{array}{l}\text { WVU Educational Sales Services per } \\
\text { Graduate Student in Dollars (U) }\end{array}$ & 18,300 & 5,000 & 12,800 & 25,600 \\
\hline $\begin{array}{l}\text { WVU Auxiliary Fee per Graduate Student in } \\
\text { Dollars (U) }\end{array}$ & 13,260 & 2,190 & 10,780 & 16,140 \\
\hline $\begin{array}{l}\text { WVU Recurring Expenditure per Graduate } \\
\text { Student in Dollars (U) }\end{array}$ & 11,597 & 1,186 & 9,687 & 13,257 \\
\hline $\begin{array}{l}\text { Industrial Units with less than 10,000 workers } \\
\text { (I) }\end{array}$ & 808.9 & 271.61 & 259.64 & $1,852.79$ \\
\hline Educational Service Jobs (I) & 338.21 & 621.74 & 0 & 5,326 \\
\hline $\begin{array}{l}\text { Ratio of STEM to Non-STEM Average Wages } \\
\text { (I) }\end{array}$ & 2.84 & 1.97 & 0.42 & 11.45 \\
\hline Share of Hi-Tech Employment (I) & 0.6 & 0.2 & 0.4 & 0.85 \\
\hline Metropolitan Statistical Area Indicator (C) & 0.31 & 0.46 & 0 & 1 \\
\hline $\begin{array}{l}\text { Ratio of Local Government Earning to Local } \\
\text { Government Employment in Dollars (G) }\end{array}$ & 4,157 & 514 & 2,489 & 5,334 \\
\hline
\end{tabular}

Source: Author computed 
Table 6 Summary Statistics for Patents per STEM Industrial Unit Model

\begin{tabular}{|l|c|c|c|c|}
\hline \multicolumn{1}{|c|}{ Variable } & Mean & Std. dev. & Min & Max \\
\hline Patents per STEM Industrial Unit (D) & 0.002 & 0.003 & 0 & 0.03 \\
\hline $\begin{array}{l}\text { WVU Ratio of STEM Grants per } \\
\text { Undergraduate Student (U) }\end{array}$ & 2,220 & 200 & 1,990 & 2,630 \\
\hline WVU Number of STEM graduate students (U) & $1,650.25$ & 50.62 & 1,581 & 1,711 \\
\hline $\begin{array}{l}\text { Ratio of Non-STEM R\&D Expenditure to } \\
\text { Number of STEM Post-Doctorate Student in } \\
\text { Dollars (U) }\end{array}$ & 26,819 & 10,502 & 7,837 & 43,962 \\
\hline $\begin{array}{l}\text { Ratio of STEM Federal Grant to Number of } \\
\text { STEM Post-Doctorate Student in Dollars (U) }\end{array}$ & 40,872 & 10,392 & 19,913 & 54,856 \\
\hline Number of Graduate Students (U) & $5,347.29$ & 172.21 & 5,105 & 5,595 \\
\hline $\begin{array}{l}\text { Manufacturing Sector Average Wage in } \\
\text { Dollars (I) }\end{array}$ & $10,956.69$ & $22,406.80$ & 0 & 99,076 \\
\hline Mining Sector Average Wage in Dollars (I) & $25,437.21$ & $24,542.77$ & 0 & 91,849 \\
\hline $\begin{array}{l}\text { Metropolitan Statistical Area and Presence of } \\
\text { University Indicator (C) }\end{array}$ & 0.16 & 0.37 & 0 & 1 \\
\hline $\begin{array}{l}\text { Ratio of Federal Government Expenditure to } \\
\text { Federal Employment in Dollars (G) }\end{array}$ & $1,882.08$ & $1,141.15$ & 118.96 & $6,019.46$ \\
\hline
\end{tabular}

Source: Author computed

In the above tables (1-6), the STEM and Non-STEM fields are defined as stipulated by the U.S. Homeland Security. STEM is an acronym for the fields of science, technology, engineering and math. STEM workers have at least a college degree and earn higher wages than non-STEM workers (Department of Homeland Security, 2011; Langdon et al., 2011).

The departments of WVU are classified into STEM and non-STEM that include faculty, students and staff. Correspondingly, grants, expenditures and various form of revenues that the university earns are segregated into STEM and non-STEM categories. Employing the same definition for STEM categories at the industry level, the industries are segregated into STEM and non-STEM units. Similarly, wages, earnings and employment for STEM and Non-STEM industries are computed. 
Industries identified as construction, educational services, finance and insurance, health and social assistance services, information technology, manufacturing, mining and professional, scientific and technical services are classified as STEM industries. The rest are part of the nonSTEM category.

The indicator for Metropolitan Statistical Area (MSA) is based on the definition provided by U.S. Census Bureau. An indicator is created to account for presence of other universities in addition to WVU in other counties which are part of the West Virginia State higher education system. The indicators of MSA and other universities are combined to create a new indicator identifying the presence of university in a MSA. This indicator is used as a measure of knowledge spillover in a number of regression models.

The variables constructed above are employed in the next section to estimate regression parameters and to test the research hypotheses. Additionally, the dependent and the exogenous variables are transformed into logarithm for estimation purposes except for the indicator variables. The advantage of a logarithm transformation is two folds first, it reduces the variance of the variable and is more robust to outliers and second, the coefficients obtained from a double-log model are elasticities. Elasticities are unit less and are easy to interpret.

The variables defined in tables (1) to (6) are employed to estimate the regression models. The results of the regressions are reported in the next section. 


\section{Chapter 5. RESULTS and ANALYSIS}

Based on the methodology and the data description provided in the previous two sections, the regression models are estimated and the results are explained in this section. The university variables are labeled as "U", industry characteristics as "I", community level variables as "C" and measures of government activity as "G".

\subsection{Least Square Dummy Variable Estimations}

Table 7 reports the Least Square Dummy Variable (LSDV) regression results for the dependent variable Income per capita. Since different measures of university characteristics are observed over a short time span of seven years in the panel dataset, there is strong correlation among the different university variables. The correlation structure is broken down to some extent by dividing university grants, expenditures, educational sales and services by university faculty, graduate, undergraduate, STEM, non-STEM, doctoral and post doctorate students. This transformation reduces strong correlation among various university variables but still the correlation structure remains high. So they cannot be used together in a model specification due to multicolinearity issues. Therefore, only one characteristic of the university is introduced at a time from models (1) to (3) keeping the control variables same in all the specifications.

All variables in the regression are expressed in logarithm including the dependent variable and the independent variables except the indicator for metropolitan statistical area (MSA) and presence of a university. Therefore, the coefficients obtained from these regressions are elasticities and the coefficients representing MSA plus university indicators are growth rates.

The university variables have a positive impact on income per capita. A $1 \%$ increase in university variables specified in models (1) -(3) results in an increase in per capita income from 
$0.14 \%$ to $0.40 \%$ keeping other variables constant. Specifically, an increase in WVU STEM R\&D expenditure per faculty results in more research by faculty and more investment in skill development among faculty and students that translates into higher income per capita at the county level. Repeated investments in knowledge creation in university captured by the term recurring expenditure per tenured faculty results in positive impact on income per capita. Education Sales and Services include receipt of payment by the university for providing consulting and extension services to community and local industries which result in knowledge spillovers. The variable education sales and services per graduate student captures this aspect and it has a positive and significant effect on income per capita.

Industries that provide educational services have a positive impact on income per capita and it remains stable across all the three specifications. The educational service representative unit coefficient suggests that a $1 \%$ increase in educational service units results in $0.02 \%$ increase in per capita income. Job to population ratio is a measure of employment at the community level. The coefficient remains fixed across all the specifications and suggests a $1 \%$ increase in proportion of jobs in a community results in $0.26 \%$ increase in income per capita.

An increase in building permits which is a measure of infrastructural development in a county, results in an increase in income per capita keeping other variables fixed. Location of a county in a metropolitan statistical area and also presence of a university which is a part of West Virginia state education system signifies access to more education, better infrastructure, job opportunities. Their effects are positive and significant on income per capita. The coefficient ranges from 0.04 to 0.05 across the three model specifications. It means that the presence of a university in a metropolitan statistical area results in 4 to $5 \%$ increase in income per capita keeping other variables constant. 
Table 7 Dependent Variable: Logarithm of Income per Capita

\begin{tabular}{|l|c|c|c|}
\hline \multicolumn{1}{|c|}{ Variable } & Model 1 & Model 2 & Model 3 \\
\hline Log- West Virginia University (WVU) STEM R\&D & $0.23^{* *}$ & - & - \\
Expenditure per Faculty (U) & $(0.04)$ & & \\
\hline Log- WVU Recurring Expenditure per Tenured & - & $0.40^{* *}$ & - \\
Faculty (U) & & $(0.061)$ & \\
\hline Log- WVU Education Sales and Services per & - & - & $0.14^{* *}$ \\
Graduate Student (U) & & & $(0.02)$ \\
\hline Log - Educational Service Representative Units (I) & $0.02^{* *}$ & $0.02^{* *}$ & $0.02^{* *}$ \\
& $(0.01)$ & $(0.01)$ & $(0.01)$ \\
\hline Log- Job to Population Ratio (C) & $0.26^{* *}$ & $0.26^{* *}$ & $0.26^{* *}$ \\
& $(0.02)$ & $(0.02)$ & $(0.02)$ \\
\hline Log- Building Permits (C) & $0.02^{* *}$ & $0.02^{* *}$ & $0.02^{* *}$ \\
& $(0.01)$ & $(0.01)$ & $(0.01)$ \\
\hline Metropolitan Area and Presence of University & $0.05^{* *}$ & $0.04^{* *}$ & $0.05^{* *}$ \\
Indicator (C) & $(0.01)$ & $(0.01)$ & $(0.01)$ \\
& & & \\
\hline Log- Ratio of Federal Earnings to Federal & $0.22^{* *}$ & $0.19^{* *}$ & $0.20^{* *}$ \\
Government Employment (G) & $(0.04)$ & $(0.04)$ & $(0.03)$ \\
\hline Log- Local Government Earnings Per Capita (G) & $0.04^{* *}$ & $0.04^{* *}$ & $0.04^{* *}$ \\
& $(0.02)$ & $(0.02)$ & $(0.02)$ \\
\hline Intercept & $8.08^{*}$ & $6.47^{*}$ & $8.94^{*}$ \\
& $(0.20)$ & $(0.36)$ & $(0.19)$ \\
\hline Observations & 385 & 385 & 385 \\
\hline Adjusted R & 0.74 & 0.75 & 0.75 \\
\hline F- Statistics & $156.42^{* *}$ & $163.76^{* *}$ & $163.59^{* *}$ \\
\hline
\end{tabular}

Notes: Standard errors are provided in parentheses. Regression coefficients are rounded to nearest two decimal places. A single asterisk $(*)$ implies significance at 0.05 level in a two-tailed test. A double asterisk $(* *)$ implies significance at 0.01 level in a two tailed test. Dummy variables to control for time fixed effects are not reported here due space issues but are jointly found to be significant in a two tailed F-test.

This result conforms to the findings of Glaeser and Maré (2001), who find evidence of workers earning 33\% more in metropolitan statistical areas (MSA) than in non-MSA locations. They find that cities accelerate the growth of human capital.

The productivity of federal and local government is captured in two other control variables, namely, federal earnings to federal employment and local earning per capita ${ }^{20}$. These two variables

\footnotetext{
${ }^{20}$ The state government variables in the form of revenues and expenditures are found to have a very strong correlation with their federal and local counterparts. Therefore, in order to avoid multicollinearity issues the study has dropped state government variables from the model specifications. Additionally, the federal and local government variables may be dropped to include the state government budgetary characteristics in the model specifications.
} 
seem to have a positive and significant effect across all the three specifications. Thus, indicating that government's earning in the form of tax revenue from local and federal sources have positive impact on income per capita. Since there is a positive association between government earnings and expenditure, greater earning means higher expenditure by the government at the community level which results in greater social welfare.

All coefficients from the regression specifications are found to be statistically significant in a two tailed t-test. The adjusted $\mathrm{R}^{2}$ ranges from 0.74 to 0.75 across the model specifications suggesting that the model fits well to the data. The F-tests for all models suggest that the fitted models are robust and therefore reject the null hypothesis that all the regression coefficients are collectively zero.

Table 8 Dependent Variable: Logarithm of Total Average Wage in Industries

\begin{tabular}{|l|c|c|c|}
\hline \multicolumn{1}{|c|}{ Variable } & Model 1 & Model 2 & Model 3 \\
\hline Log-WVU Educational Sales and Services per Faculty (U) & $\begin{array}{c}0.10^{* *} \\
(0.04)\end{array}$ & - & - \\
\hline Log- WVU Recurring Expenditure per Tenured Faculty (U) & - & $0.23^{* *}$ & - \\
& & - & $-11)$ \\
\hline Log- WVU STEM Post-Doctoral Students (U) & - & $0.05^{* *}$ \\
& & & $(0.02)$ \\
\hline Log -STEM Industrial Earnings (I) & $0.01^{* *}$ & $0.01^{* *}$ & $0.01^{* *}$ \\
& $(0.01)$ & $(0.01)$ & $(0.01)$ \\
\hline Log- Violent Crime (C) & $-0.04^{* *}$ & $-0.04^{* *}$ & $-0.04^{* *}$ \\
& $(0.01)$ & $(0.01)$ & $(0.01)$ \\
\hline Metropolitan Statistical Area and Presence of University & $0.02^{* *}$ & $0.02^{* *}$ & $0.02^{* *}$ \\
Indicator (C) & $(0.01)$ & $(0.01)$ & $(0.01)$ \\
& & & \\
\hline Log- Ratio of Local Government Earnings to Local & $0.43^{* *}$ & $0.42^{* *}$ & $0.46^{* *}$ \\
Government Employment (G) & $(0.07)$ & $(0.08)$ & $(0.07)$ \\
\hline Intercept & $7.60^{*}$ & $6.25^{*}$ & $7.49^{*}$ \\
& $(0.23)$ & $(0.51)$ & $(0.21)$ \\
\hline Observations & 385 & 385 & 385 \\
\hline Adjusted R ${ }^{2}$ & 0.51 & 0.50 & 0.51 \\
\hline F- Statistics & $79.55^{* *}$ & $79.11^{* *}$ & $79.29^{* *}$ \\
\hline
\end{tabular}

Notes: Standard errors are provided in parentheses. Regression coefficients are rounded to nearest two decimal places. A single asterisk (*) implies significance at 0.05 level in a two-tailed test. A double asterisk (**) implies significance at 0.01 level in a two tailed test. Dummy variables to control for time fixed effects are not reported here due space issues but are found to be significant in a two tailed F-test. 
Table 8, reports the estimates for the impact of university, industry, government and community level characteristics on the development indicator total average wage in industries. University's services in the form of consulting, extension services etc. captured by educational sales and services per faculty variable seems to have a positive and significant impact on total average wage in industries.

Similarly, recurring expenditure by university per tenured faculty which measures the university's investments on established and highly knowledgeable tenured faculty who are associated with innovative hi-tech industries result in knowledge spillover to local industries. This aspect is captured in model (2), which suggests that a $1 \%$ increase in recurring expenditure per tenured faculty results in $0.23 \%$ increase in total average wage in industries keeping other variables fixed.

In model (3), an increase in the number of STEM post doctorate students results in $0.05 \%$ increase in total average wage in industries keeping other variables constant. This variable is a measure of high quality human capital. Post-doctorate students who have already successfully completed their doctoral degree in STEM fields often work in highly innovative research projects in collaboration with high tech industries.

Correspondingly, Rosenthal and Strange (2008) finds a similar positive impact on wages of less than college educated workers when in close proximity to college educated workers. The study states that wages increased by $12 \%$ for the less than college educated workers.

Industries engaged in STEM fields seem to have a positive and significant impact on total average wage in industries. This coefficient suggests that STEM industry earnings have more 
impact on total average wage compared to non-STEM industry earnings, keeping other variables fixed. Based on models (1-3), this coefficient is statistically significant at $0.01 \%$ level of significance.

Increase in violent crime adds to the existing cost of industries and it also creates a deterrence for new industrial initiatives. This notion gets reflected in all the three specifications where crime has a negative and significant impact on total average wage. Presence of a university in metropolitan statistical area increases total average wage by $2 \%$ across all the three specifications. This is due to the reason that metropolitan statistical areas have high wage rates, more job opportunities and availability of skilled labor due to presence of universities.

Local government's productivity captured by the variable local government earnings to local government employment ranges from 0.42 to 0.46 across the three models. This coefficient suggests that a $1 \%$ increase in local government earnings to local government employment results in $0.42-0.46 \%$ increase in total average wage in industry, while keeping other variables fixed.

All the coefficients from the regression specifications are found to be statistically significant in a two tailed t-test. The F-statistics for all the three models are found to be statistically significant. The adjusted $\mathrm{R}^{2}$ ranges from 0.50 to 0.51 across the three specifications.

Table 9 reports the LSDV estimates for the third development indicator - namely, poverty rate. Model 1, uses non-STEM R\&D expenditure per post-doctorate student as an explanatory variable to capture the impact of university on local poverty rate. In model 2, a $1 \%$ increase in the size of graduate students assists in reducing poverty rate by $0.77 \%$ keeping other variables fixed. 
The result suggests that investment in highly skilled labor aids in reducing poverty since highly skilled labor benefits the community through various direct ${ }^{21}$ and indirect ${ }^{22}$ channels which in turn reduces poverty. Industries engaged in STEM fields have positive spillover effects on employment and infrastructure creation at the local county level. That may translate into lowering of poverty rate. Models (1) and (2), reports evidence of positive industrial spillover on poverty. A $1 \%$ increase in earnings of industries involved in STEM fields reduces poverty by nearly $0.2 \%$ keeping other variables fixed. Metropolitan statistical areas have in general a lower incidence of poverty due to better amenities, employment opportunities and governmental programs as depicted in models (2) and (3).

Table 9 Dependent Variable: Logarithm of Poverty Rate

\begin{tabular}{|l|c|c|}
\hline \multicolumn{1}{|c|}{ Variable } & Model 1 & Model 2 \\
\hline $\begin{array}{l}\text { Log-WVU Non-STEM R\&D Expenditure per Post Doctorate } \\
\text { Student (U) }\end{array}$ & $\begin{array}{c}-0.07^{* *} \\
(0.03)\end{array}$ & - \\
\hline Log- Number of STEM Graduate Students in WVU (U) & - & $-0.77^{* *}$ \\
& & $(0.40)$ \\
\hline Log -STEM Industry Earnings (I) & $-0.04^{* *}$ & $-0.04^{* *}$ \\
& $(0.01)$ & $(0.01)$ \\
\hline Metropolitan Statistical Area Indicator (C) & $-0.20^{* *}$ & $-0.19^{* *}$ \\
& $(0.03)$ & $(0.03)$ \\
\hline Log- Federal Government Employment per capita (G) & $-0.03^{* *}$ & $-0.03^{* *}$ \\
& $(0.02)$ & $(0.02)$ \\
\hline Intercept & $3.83^{*}$ & $9.13^{*}$ \\
& $(0.20)$ & $(2.94)$ \\
\hline Observations & 385 & 385 \\
\hline Adjusted ${ }^{2}$ & 0.21 & 0.20 \\
\hline F- Statistics & $25.75^{* *}$ & $25.01^{* *}$ \\
\hline
\end{tabular}

Notes: Standard errors are provided in parentheses. Regression coefficients are rounded to nearest two decimal places. A single asterisk (*) implies significance at 0.05 level in a two-tailed test. A double asterisk $(* *)$ implies significance at 0.01 level in a two tailed test. Dummy variables to control for time fixed effects are not reported here due space issues but are found to be significant in a two tailed F-test.

\footnotetext{
${ }^{21}$ Creation of high quality human capital results in spillover of knowledge at the community level which encourages people to take education and training that results in mitigating poverty

${ }^{22}$ High quality labor such as graduate students help in generation of income both for themselves as well as for the university which may result in higher tax revenue for the government. The additional revenue will help government in undertaking more social welfare programs like poverty alleviation.
} 
Increase in Federal Government employment reduces poverty rate. In this specification, a $1 \%$ increase in federal government employment per capita reduces poverty by $0.03 \%$ keeping other factors fixed. The adjusted $\mathrm{R}^{2}$ of the two models are 0.21 and 0.20 respectively. All the coefficients from the regression specifications are found to be statistically significant in a two tailed t-test.

Table 10 reports the regression results for the fourth development indicator - namely, public school enrollment per capita. Three university variables are identified that contribute to public school enrollment in model specifications (1) - (3). Each of the three variables capture how WVU's grants, expenditures and investments effect further enrollment of students in the public school system. University often works collaboratively with the public school system through seminars, extension and training programs as mentioned in one of the "WVU 2020 Strategic Plan for the Future" - to engage with the Pre K - 12 education system and the community and technical college system throughout the state. The above mentioned collaborative effort by the university seems to have a positive impact on the public school system. The regression coefficients from models (1) -(3) suggest that grants per undergraduate student, recurring expenditure per doctorate student and capital asset investment per doctoral student have positive and significant impact on public school enrollment per capita. The coefficients suggest that these university factors raise public school enrollment by $0.05 \%$ to $0.11 \%$ across the models keeping other variables fixed.

An increase in the ratio of STEM to Non-STEM jobs in industry results in higher public school enrollment as suggested by the specified models. The coefficient is stable across all the specifications. STEM jobs require more technical skills and rigorous training in both graduate and undergraduate programs. Therefore, if the ratio of STEM to non-STEM jobs increases, the demand for STEM education drastically increases in the community that results in higher enrollment in 
public schools. Enrollment in public schools is the first step in obtaining higher STEM education in the future.

Violent crimes generally have a deterrence effect on any productive economic activity that gets reflected in the coefficients in all the three specifications. Increase in violent crime by $1 \%$ reduces public school enrollment by nearly $0.2 \%$.

Table 10 Dependent Variable: Logarithm of Public School Enrollment Per Capita

\begin{tabular}{|l|c|c|c|}
\hline \multicolumn{1}{|c|}{ Variable } & Model 1 & Model 2 & Model 3 \\
\hline Log-WVU Grants per Undergraduate Student (U) & $\begin{array}{c}0.11^{* *} \\
(0.03)\end{array}$ & - & - \\
\hline $\begin{array}{l}\text { Log- WVU Recurring Expenditure per Post } \\
\text { Doctorate Student (U) }\end{array}$ & - & $\begin{array}{c}0.05^{* *} \\
(0.02)\end{array}$ & - \\
\hline Log- WVU Capital Asset Investment per Doctoral & - & - & $0.06^{* *}$ \\
Students (U) & & & $(0.02)$ \\
\hline Log -Ratio of STEM to NON STEM Jobs in & $0.03^{* *}$ & $0.02^{* *}$ & $0.03^{* *}$ \\
Industries (I) & $(0.01)$ & $(0.01)$ & $(0.01)$ \\
\hline Log- Violent Crime (C) & $-0.02^{* *}$ & $-0.02^{* *}$ & $-0.02^{* *}$ \\
& $(0.01)$ & $(0.01)$ & $(0.01)$ \\
\hline Log- Federal Government Expenditure per Federal & $0.03^{* *}$ & $0.03^{* *}$ & $0.03^{* *}$ \\
Employment (G) & $(0.01)$ & $(0.01)$ & $(0.01)$ \\
\hline Intercept & $2.39^{*}$ & $2.12^{*}$ & $2.19^{*}$ \\
& $(0.01)$ & $(0.23)$ & $(0.18)$ \\
\hline Observations & 385 & 385 & 385 \\
\hline Adjusted R & 0.13 & 0.12 & 0.13 \\
\hline F- Statistics & $15.90^{* *}$ & $14.52^{* *}$ & $15.06^{* *}$ \\
\hline
\end{tabular}

Notes: Standard errors are provided in parentheses. Regression coefficients are rounded to nearest two decimal places. A single asterisk $(*)$ implies significance at 0.05 level in a two-tailed test. A double asterisk $(* *)$ implies significance at 0.01 level in a two tailed test. Dummy variables to control for time fixed effects are not reported here due space issues but are found to be significant in a two tailed F-test.

An increase in federal government expenditure per federal employee which is a measure of federal government's productivity has a positive impact on public school enrollment. The impact is about $0.03 \%$ keeping other variables fixed. Since there is a strong correlation among government revenue and government spending, this measure is being used as a proxy for 
government's productivity ${ }^{23}$. The summary statistics of the regressions are found to be robust based on $\mathrm{F}$ statistics and adjusted $\mathrm{R}^{2}$.

The impact of university, industry, community and governmental characteristics are examined on the fifth development indicator namely industrial productivity. Industrial productivity is measured using the variable industrial earnings per industrial unit. The results are reported in Table 11.

Table 11 Dependent Variable: Logarithm of Industrial Earnings per Industrial Unit

\begin{tabular}{|l|c|c|c|}
\hline Variable & Model 1 & Model 2 & Model 3 \\
\hline Log-WVU Educational Sales Services per Graduate & $\begin{array}{c}0.14^{* *} \\
(0.05)\end{array}$ & - & - \\
Student (U) & - & $0.22^{* *}$ & - \\
\hline Log- WVU Auxiliary Fee per Graduate Student(U) & & - & $0.08)$ \\
\hline Log- WVU Recurring Expenditure per Graduate & - & - & $(0.12)$ \\
Student (U) & & & $-0.60^{* *}$ \\
\hline Log -Industrial Units with less than 10,000 workers & $-0.60^{* *}$ & $-0.60^{* *}$ & $(0.03)$ \\
(I) & $0.01^{* *}$ & $0.01^{* *}$ & $0.01^{* *}$ \\
\hline Log- Educational Service Jobs (I) & $(0.01)$ & $(0.01)$ & $(0.01)$ \\
\hline Log- Ratio of STEM to Non-STEM Average Wages & $0.07^{* *}$ & $0.07^{* *}$ & $0.07^{* *}$ \\
(I) & $(0.01)$ & $(0.01)$ & $(0.01)$ \\
\hline Log- Share of Hi-Tech Employment (I) & $0.08^{* *}$ & $0.08^{* *}$ & $0.08^{* *}$ \\
& $(0.02)$ & $(0.02)$ & $(0.02)$ \\
\hline Metropolitan Statistical Area Indicator (C) & $0.08^{* *}$ & $0.08^{* *}$ & $0.08^{* *}$ \\
& $(0.02)$ & $(0.02)$ & $(0.02)$ \\
\hline Log - Ratio of Local Government Earning to Local & $0.42^{* *}$ & $0.39^{* *}$ & $0.44^{* *}$ \\
Government Employment (G) & $(0.10)$ & $(0.11)$ & $(0.10)$ \\
\hline Intercept & $8.02^{*}$ & $7.80^{*}$ & $6.84^{*}$ \\
& $(0.40)$ & $(0.36)$ & $(0.45)$ \\
\hline Observations & 385 & 385 & 385 \\
\hline Adjusted R & 0.73 & 0.73 & 0.73 \\
\hline F- Statistics & $150.53^{* *}$ & $150.87^{* *}$ & $149.30^{* *}$ \\
\hline
\end{tabular}

Notes: Standard errors are provided in parentheses. Regression coefficients are rounded to nearest two decimal places. A single asterisk (*) implies significance at 0.05 level in a two-tailed test. A double asterisk (**) implies significance at 0.01 level in a two tailed test. Dummy variables to control for time fixed effects are not reported here due space issues but are found to be significant in a two tailed F-test.

\footnotetext{
${ }^{23}$ The correlation between revenue and expenditure of the federal government in West Virginia over the period of $2001-2007$ is 0.89
} 
Collaboration of university with local industries in the form of extension and consulting services have positive and statistically significant impact on industrial earnings per industrial unit. The variable educational sales and services per graduate student captures this aspect.

The coefficient suggests that if this variable increases by $1 \%$, industrial earnings per industrial unit increases by $0.14 \%$ keeping other variables fixed. University collects revenue from transportation services, sporting events, sponsorships etc., while collaborating with local industries. The revenue from the sources mentioned above are accounted for in the university's auxiliary fees. Auxiliary fees per graduate student has a positive and significant impact on industrial earnings per industrial unit. A $1 \%$ increase in auxiliary fees per graduate student results in $0.22 \%$ increase in industrial earnings per industrial unit.

Additionally, recurring investment on graduate students supports the maintenance of a steady stock of human capital in the area and consequently produces a knowledge spillover in terms of higher industrial productivity. The regression parameter corresponding to recurring expenditure per graduate student captures this aspect. It has a positive and significant impact on industrial earnings per industrial unit. These results are consistent with the findings of Woodward et al. (2006). They find evidence of positive knowledge spillovers from universities on local industries in terms of higher profit earning capabilities.

Industrial units with less than 10,000 employees seem to have a negative and significant impact on industrial earnings per industrial unit across all the three specifications. This may be due to the fact that the time series is limited to seven years and small industries take a substantial amount of time before they turn profitable and enjoy economies of scale. Industrial units that are engaged in providing educational services have positive and significant impact on the dependent variable keeping other variables fixed. The coefficient is 0.01 across all the three models. A $1 \%$ 
increase in STEM average wage to non-STEM average wage in industry results in $0.07 \%$ increase in industrial earnings per industrial unit keeping other variables fixed. This is due to the reason that STEM jobs involve high skilled labor and the wage rate is higher in STEM jobs compared to non-STEM jobs per se.

This result is confirmed by a separate study conducted by Arcidiacono (2004), that finds the return to education is higher for STEM jobs requiring STEM college majors such as natural science and business. More specifically, math ability has a higher labor market return whereas verbal ability has a slight impact on labor market values.

Furthermore, higher productivity in STEM industries get translated into higher industrial earnings per industrial unit. An increase in the share of high tech employment by $1 \%$ results in a $0.08 \%$ increase in industrial earnings per unit keeping other variables fixed. More employment in hi-tech industries mean greater engagement of high quality labor that has higher levels of technological know-how resulting in higher industrial earnings per industrial unit.

Location also plays an important part on industrial earnings per industrial unit. Locating in a metropolitan statistical area results in the increase in industrial earnings per industrial unit by $8 \%$ keeping other variables constant. Metropolitan statistical areas have better network, infrastructure and clustering of industries compared to non-MSA areas, and therefore they seem to have larger impact on industrial productivity.

The local government maintains a key role in providing amenities like security, transportation, law and order etc. in the economy. These amenities assist in the establishment and smooth functioning of the industrial sector. The productivity of government is captured by the variable ratio of local government earning to local government employment. The coefficient 
ranges from 0.39 to 0.44 across the three models, which suggests that local government productivity has a positive and significant influence on industrial earnings per industrial unit.

All the parameter estimates across the three equations are found to be significant in a two tailed t-test. F-statistics is significant across all the three specifications and adjusted $\mathrm{R}^{2}$ is stable across all the three models at 0.73 .

In Table 12, a range of university factors considered that influence patents per STEM industrial unit. All the university factors cannot be considered simultaneously in one specification due to strong correlation among the measures. Therefore, one variable at a time is tested across models (1)- (5).

University works collaboratively with local industries for knowledge creation and the positive spillover of knowledge from university greatly impacts industrial research and development. According to Audretsch and Stephan (1996) university faculty are more likely to collaborate with local area firms if the industry has a significant local area presence. That is, university research is more productive and has higher knowledge spillovers on industries when the local area has an existing high-tech production concentration.

In West Virginia, the manufacturing and mining industry constitute a major part of the industrial sector. Consequently, resulting in a significant university knowledge spillover on industrial research and innovations. One of the highest and most stringent quality measures of industrial research and innovation is the creation of new patents. The ratio of STEM grants per undergraduate student has a positive and significant impact on patents per industrial unit. 
Table 12 Dependent Variable: Patents per STEM Industrial Unit

\begin{tabular}{|c|c|c|c|c|c|}
\hline Variable & Model 1 & Model 2 & Model 3 & Model 4 & Model 5 \\
\hline $\begin{array}{l}\text { WVU Ratio STEM Grants per } \\
\text { Undergraduate Student }(\mathrm{U})\end{array}$ & $\begin{array}{l}0.008 * * \\
(0.002)\end{array}$ & - & - & - & - \\
\hline $\begin{array}{l}\text { WVU Number of STEM } \\
\text { graduate students (U) }\end{array}$ & - & $\begin{array}{l}0.002 * * \\
(0.001)\end{array}$ & - & - & - \\
\hline $\begin{array}{l}\text { Ratio of Non-STEM R\&D } \\
\text { Expenditure to Number of } \\
\text { STEM Post-Doctorate Student } \\
\text { (U) }\end{array}$ & - & - & $\begin{array}{l}0.001 * * \\
(0.001)\end{array}$ & - & - \\
\hline $\begin{array}{l}\text { Ratio of STEM Federal Grant to } \\
\text { Number of STEM Post- } \\
\text { Doctorate Student (U) }\end{array}$ & - & - & - & $\begin{array}{l}0.001 * * \\
(0.001)\end{array}$ & - \\
\hline $\begin{array}{l}\text { Number of Graduate Students } \\
\text { (U) }\end{array}$ & - & - & - & - & $\begin{array}{l}0.001 * * \\
(0.001)\end{array}$ \\
\hline $\begin{array}{l}\text { Manufacturing Sector Average } \\
\text { Wage (I) }\end{array}$ & $\begin{array}{l}0.001 * * \\
(0.001)\end{array}$ & $\begin{array}{l}0.001 * * \\
(0.001)\end{array}$ & $\begin{array}{l}0.001 * * \\
(0.001)\end{array}$ & $\begin{array}{l}0.001 * * \\
(0.001)\end{array}$ & $\begin{array}{l}0.001 * * \\
(0.001)\end{array}$ \\
\hline $\begin{array}{l}\text { Mining Sector Average Wage } \\
\text { (I) }\end{array}$ & $\begin{array}{l}0.001 * * \\
(0.001)\end{array}$ & $\begin{array}{l}0.001 * * \\
(0.001)\end{array}$ & $\begin{array}{l}0.001 * * \\
(0.001)\end{array}$ & $\begin{array}{l}0.001 * * \\
(0.001)\end{array}$ & $\begin{array}{l}0.001 * * \\
(0.001)\end{array}$ \\
\hline $\begin{array}{l}\text { Metropolitan Statistical Area } \\
\text { and Presence of University } \\
\text { Indicator }(C)\end{array}$ & $\begin{array}{l}0.005 * * \\
(0.001)\end{array}$ & $\begin{array}{l}0.005 * * \\
(0.001)\end{array}$ & $\begin{array}{l}0.005 * * \\
(0.001)\end{array}$ & $\begin{array}{l}0.005 * * \\
(0.001)\end{array}$ & $\begin{array}{l}0.005 * * \\
(0.001)\end{array}$ \\
\hline $\begin{array}{l}\text { Ratio of Federal Government } \\
\text { Expenditure to Federal } \\
\text { Government Employment }(\mathrm{G})\end{array}$ & $\begin{array}{c}0.001 \\
(0.001)\end{array}$ & $\begin{array}{c}0.001 \\
(0.001)\end{array}$ & $\begin{array}{c}0.001 \\
(0.001)\end{array}$ & $\begin{array}{c}0.001 \\
(0.001)\end{array}$ & $\begin{array}{c}0.001 \\
(0.001)\end{array}$ \\
\hline Intercept & $\begin{array}{l}-0.016^{*} \\
(0.005)\end{array}$ & $\begin{array}{l}-0.030 * \\
(0.015)\end{array}$ & $\begin{array}{l}-0.002 \\
(0.001)\end{array}$ & $\begin{array}{l}-0.003 \\
(0.002)\end{array}$ & $\begin{array}{c}-0.030 * \\
(0.015)\end{array}$ \\
\hline Observations & 385 & 385 & 385 & 385 & 385 \\
\hline Adjusted $\mathrm{R}^{2}$ & 0.09 & 0.08 & 0.08 & 0.08 & 0.08 \\
\hline F- Statistics & $8.77 * *$ & $7.22 * *$ & $7.37 * *$ & $7.29 * *$ & $7.32 * *$ \\
\hline
\end{tabular}

Notes: Standard errors are provided in parentheses. Regression coefficients are rounded to nearest three decimal places. A single asterisk $(*)$ implies significance at 0.05 level in a two-tailed test. A double asterisk $(* *)$ implies significance at 0.01 level in a two tailed test. Dummy variables to control for time fixed effects are not reported here due space issues but are found to be significant in a two tailed F-test. 
The coefficient suggests that if STEM federal grants per undergraduate is increased by $\$ 1,000$, it results in the creation of 8 patents per industrial unit keeping other factors fixed. Similarly, in model 2, if the number of STEM graduate students increase by 1000 it results in the creation of 2 patents per industrial unit keeping other variables fixed. This coefficient suggests that STEM graduate students are directly involved in the knowledge creation process therefore an increase in their number has a positive influence on patent creation.

Moreover, some form of general expenditure additional to STEM expenditure aids in setting up the ideal infrastructure and resources in the university for high tech research and development. These expenditures ultimately assist in knowledge creation in the form of new patents. The ratio of non-STEM R\&D expenditure per post doctorate student captures this aspect. The coefficient is found to have a positive and significant impact on patent creation per industrial unit in model 3.

Federal grants provide additional financial resources for research and development and greater collaboration with local industries for knowledge creation. Furthermore, STEM post doctorate students are highly skilled labor who already have a doctoral degree and experience working in high quality research in STEM fields. The ratio of STEM federal grant per STEM post doctorate student is used as one of the measures of knowledge creation in model 4. It has a positive and significant impact on patents per STEM industrial unit. The coefficient suggests that a $\$ 1000$ increase in STEM Federal grant per STEM doctorate student results in the creation of 1 patent per STEM industrial unit keeping other variables fixed.

In model 5, the number of graduate student is employed as one of the university characteristics to examine its impact on patent creation and it is found to have a positive and significant influence. Increase in the number of graduate students in a university increases the pool 
of high quality labor in the local economy that generates positive knowledge spillover to local industries through collaborative research and consulting services.

Jaffe (1989), Anselin (2000), Andersson et al. (2009) in separate studies found similar positive university knowledge spillovers on patent creation in local industries corroborating the results from this analysis.

Most of the utility patents created are on process improvements in manufacturing and mining industries. Additionally, both manufacturing and mining jobs belong to the STEM field and thereby have higher wage rates compared to other industries. Therefore, manufacturing and mining sector average wages are used as one of the control variables in the regression. The coefficient remains stable across all the five models and are found to be positive and statistically significant. Similarly, both mining and manufacturing sectors are one of the major industrial segments in West Virginia. A considerable amount of utility patents has been created in these industries. Therefore, it is imperative to control for mining and manufacturing sector wages in all the model specifications.

The coefficient remains the same for all the specifications and suggests that a $\$ 1,000$ increase in mining sector average wage results in the creation of 1 patent per STEM industrial unit keeping other variables fixed. Metropolitan statistical areas have on an average greater impact on patent creation compared to non-MSA areas. Since cluster of hi-tech industries, universities, high skilled labor, infrastructure, better amenities are mostly located in MSAs, they provide greater incentive to industries to invest in larger scale research and development initiatives. The regression coefficients corresponding to this variable are found to be positive and significant for all the five models. 
Government provides necessary infrastructure, transportation and legal support to protect intellectual property rights for establishment and functioning of industries engaged in knowledge creation. However, the government's support in the knowledge creation process seems to be indirect. The ratio of Federal Government Expenditure to Federal Government Employment is used as one of the controls in the model to account for a government's role in the patent creation process in the industry. The coefficients across all the five models are found to be positive but not statistically significant.

The adjusted $\mathrm{R}^{2}$ is found to be ranging from 0.08 to 0.09 across all the specifications and F-statistics is significant as well in a two tailed F-test at $95 \%$ significance level.

\subsection{Advanced Non-Spatial and Spatial Estimations}

The LSDV is an inconsistent estimator for small panels with a short time series component (Cameron and Trivedi, 2005). Therefore, the best fitted LSDV model is selected based on the adjusted $\mathrm{R}^{2}$ statistics and further used for employing panel data estimation techniques. The Hausman Specification test is conducted to select between fixed effects and random effects models for all the six development indicators. In the absence of proper theoretical guidance, Hausman test (Hausman, 1978) is a logical step to select between a fixed effects and random effects model. The Hausman test confirms the presence of both cross-sectional and time fixed effects for all the specifications involving the six development indicators ${ }^{24}$. Therefore, the fixed effects model is estimated in addition to the LSDV estimations. However, the fixed effects model fails to incorporate variables that are time invariant. Consequently, in these specifications the presence of other universities in a county, indicator for metropolitan statistical area and presence of university

\footnotetext{
${ }^{24}$ The results of Hausman Specification Tests are reported in the Result Appendix
} 
in metropolitan statistical area drop out from the fixed effects model. The fixed effects estimators are not only unbiased and efficient but also consistent over the LSDV estimates (Greene, 2003).

Breusch-Pagan Test is performed to test for cross-equation error correlation on the estimated six fixed effects panel equations ${ }^{25}$ (Breusch and Pagan, 1979). The null hypothesis of absence of cross-equation error correlation is rejected and therefore a Panel Seemingly Unrelated Regression (SUR) is estimated in a system of equations framework. A SUR regression in the presence of cross-equation error correlation is more efficient compared to individual fixed effects estimates. The panel SUR estimates provide more robust standard errors of the regression coefficients (Biorn, 2004).

Lastly, the Spatial Durbin Fixed Effects model is estimated for each of the six dependent variables to control for spatial correlation. The Moran's I statistics is computed for each of the six equations to test the presence of spatial autocorrelation. The test confirms positive spatial autocorrelation for each of the equations. Consequently, both the standard and robust Lagrange Multiplier (LM) tests are performed along with the Likelihood Ratio (LR) test to select the most appropriate spatial panel model ${ }^{26}$. Furthermore, employing Elhorst (2010) testing procedure, the Spatial Durbin Model is found to be the most favorable model for all six equations representing separate economic development indicators. Additionally, the Hausman specification test confirms that fixed effects model is appropriate over random effects specification by rejecting the null hypothesis in all the six models ${ }^{27}$.

A spatial fixed effects model is an improvement over a non-spatial fixed effects model since it accounts for spatial spillover effects and therefore the standard errors of the estimates will

\footnotetext{
${ }^{25}$ The results of Breusch-Pagan Tests are reported in the Result Appendix

${ }^{26}$ All these tests are reported in the Result Appendix

${ }^{27}$ Hausman Specification Test is reported in the Result Appendix
} 
be more precise in the latter case as compared to the former. An improvement over the spatial fixed effects model will be a spatial SUR model. However, in the absence of proper software support as stated earlier, it is not feasible to estimate a spatial SUR model at this stage. Therefore, this study limits the spatial analysis to spatial fixed effects models.

The estimates from LSDV, Fixed Effects Panel estimation, Panel SUR and Spatial Panel Durbin Fixed Effects models are reported in the following tables. The purpose of these tables is to suggest that the relationship between university variables and local area indicators remain stable and statistically significant even after using more unbiased, efficient and consistent estimators while controlling for other factors. The results are reported in Tables 13 to 19.

Table 13 reports the best LSDV estimates from Table 1 and then uses that specification to estimate Fixed Effects, Panel SUR and Spatial Panel Durbin Fixed Effects models. Since time invariant characteristics drop out of fixed effects models, presence of university in a metropolitan statistical area drops out from all the specifications except from the LSDV estimation. Comparing across LSDV, Fixed Effects and panel SUR estimates, the standard errors of the coefficients have steadily decreased or remained constant. It is consistent with the hypothesis that fixed effects and panel SUR estimates are more consistent and efficient over the LSDV estimates. Fixed effects and the panel SUR estimates for university characteristics are positive and statistically significant but the parameter coefficients are smaller compared to the LSDV estimates.

The other control variables representing industry, community and government characteristics appear to have positive and significant impact on income per capita analogous to the LSDV estimates. The last four columns report the regression coefficients from the Spatial Durbin Fixed Effects Model. This model controls for spatial spillover effects and therefore is an improvement over the Fixed Effects Model estimates provided in column 2 of Table 13. 
Table 13 Dependent Variable: Logarithm of Income per Capita

\begin{tabular}{|c|c|c|c|c|c|c|c|}
\hline Variable & LSDV & $\begin{array}{l}\text { Fixed } \\
\text { Effects }\end{array}$ & $\begin{array}{l}\text { Panel } \\
\text { SUR }\end{array}$ & $\begin{array}{c}\text { Spatial } \\
\text { Durbin } \\
\text { Fixed } \\
\text { Effects } \\
\end{array}$ & $\begin{array}{c}\text { Spatial } \\
\text { Durbin } \\
\text { Direct } \\
\text { Effects } \\
\end{array}$ & $\begin{array}{c}\text { Spatial } \\
\text { Durbin } \\
\text { Indirect } \\
\text { Effects }\end{array}$ & $\begin{array}{c}\text { Spatial } \\
\text { Durbin } \\
\text { Total } \\
\text { Effects }\end{array}$ \\
\hline $\begin{array}{l}\text { Log- West Virginia University (WVU) STEM } \\
\text { R\&D Expenditure per Faculty (U) }\end{array}$ & $\begin{array}{l}0.23 * * \\
(0.04)\end{array}$ & $\begin{array}{l}0.12 * * \\
(0.02)\end{array}$ & $\begin{array}{c}0.13 * * \\
(0.01)\end{array}$ & $\begin{array}{c}0.2371 * * \\
(0.03)\end{array}$ & $0.2348 * *$ & 0.0573 & 0.2921 \\
\hline $\begin{array}{l}\text { Log - Educational Service Representative } \\
\text { Units (I) }\end{array}$ & $\begin{array}{l}0.02 * * \\
(0.01)\end{array}$ & $\begin{array}{c}0.01 * * \\
(0.01)\end{array}$ & $\begin{array}{c}0.01 * * \\
(0.01)\end{array}$ & $\begin{array}{l}0.0161 * * \\
(0.01)\end{array}$ & $0.0165 * *$ & 0.0082 & 0.0247 \\
\hline Log- Job to Population Ratio (C) & $\begin{array}{l}0.26 * * \\
(0.02)\end{array}$ & $\begin{array}{l}0.45 * * \\
(0.04)\end{array}$ & $\begin{array}{l}0.40 * * \\
(0.03)\end{array}$ & $\begin{array}{l}0.2766^{* *} \\
(0.02)\end{array}$ & $0.2757 * *$ & 0.0227 & $0.2984 * *$ \\
\hline Log- Building Permits (C) & $\begin{array}{l}0.02 * * \\
(0.01)\end{array}$ & $\begin{array}{l}0.02 * * \\
(0.01)\end{array}$ & $\begin{array}{c}0.02 * * \\
(0.01)\end{array}$ & $\begin{array}{c}0.0181 * * \\
(0.01)\end{array}$ & $0.0181 * *$ & 0.0008 & $0.0189 *$ \\
\hline $\begin{array}{l}\text { Metropolitan Area and Presence of University } \\
\text { Indicator (C) }\end{array}$ & $\begin{array}{l}0.05 * * \\
(0.01)\end{array}$ & - & - & - & - & - & - \\
\hline $\begin{array}{l}\text { Log- Ratio of Federal Earnings to Federal } \\
\text { Government Employment }(\mathrm{G})\end{array}$ & $\begin{array}{l}0.22 * * \\
(0.04)\end{array}$ & $\begin{array}{l}0.22 * * \\
(0.03)\end{array}$ & $\begin{array}{c}0.23 * * \\
(0.03)\end{array}$ & $\begin{array}{l}0.2175 * * \\
(0.03)\end{array}$ & $0.2197 * *$ & 0.0550 & $0.2747 *$ \\
\hline $\begin{array}{l}\text { Log- Local Government Earnings Per Capita } \\
\text { (G) }\end{array}$ & $\begin{array}{l}0.04 * * \\
(0.02)\end{array}$ & $\begin{array}{c}0.30 * * \\
(0.03)\end{array}$ & $\begin{array}{c}0.27 * * \\
(0.02)\end{array}$ & $\begin{array}{l}0.0309 * * \\
(0.01)\end{array}$ & $0.0347 * *$ & $0.0951^{*}$ & $0.1298 *$ \\
\hline Intercept & $\begin{array}{l}8.08 * \\
(0.20)\end{array}$ & $\begin{array}{l}6.86^{*} \\
(0.17) \\
\end{array}$ & $\begin{array}{c}4.09 * * \\
(0.14)\end{array}$ & $\begin{array}{c}4.8596 * * \\
(0.21)\end{array}$ & - & - & - \\
\hline Spatial Autoregressive Lag Parameter $(\rho)$ & - & - & - & $\begin{array}{c}0.34 * * \\
(0.07)\end{array}$ & - & - & - \\
\hline Observations & 385 & 385 & 385 & 385 & - & - & - \\
\hline Adjusted $\mathrm{R}^{2}$ & 0.74 & 0.76 & 0.74 & - & - & - & - \\
\hline F- Statistics/Chi-Square & $156.42 * *$ & $163.76 * *$ & $204.85 * *$ & - & - & - & - \\
\hline
\end{tabular}

Notes: Standard errors are provided in parentheses. Regression coefficients are rounded to nearest two decimal places. A single asterisk $(*)$ implies significance at 0.05 level in a two-tailed test. A double asterisk $(* *)$ implies significance at 0.01 level in a two tailed test. Dummy variables to control for time fixed effects are not reported here due space issues but are found to be significant in a two tailed F-test. F-Statistics is reported for LSDV and Fixed Effects Model where as ChiSquare statistics is reported for Panel SUR model. 
WVU STEM R\&D expenditure per faculty has a positive and significant effect on income per capita keeping other variables fixed. The coefficient suggests a $1 \%$ increase in this variable results in $0.23 \%$ increase in income per capita. This coefficient is larger than the coefficients obtained from non-spatial models.

Since the Spatial Durbin Fixed Effects Model controls for spatial spillover effects, it provides a more refined estimate of university's STEM R\&D expenditure per faculty on per capita income. However, only the local government earnings per capita coefficient seems to have a positive and significant indirect effect on income per capita. Nevertheless, it is a vital finding supporting the spillover effects of the role of local government on income per capita.

The other control variables have the exact same sign, are statistically significant and within comparable magnitudes of the LSDV estimates. The adjusted $\mathrm{R}^{2}$ and $\log$ likelihood ratio are not reported due to limitations of the statistical package 'splm' in R which doesn't provide these statistics (Millo and Piras, 2012) for the Spatial Panel Durbin Fixed Effects model.

Table 14, reports the regression results for both spatial and non-spatial models for the development indicator total average industry wage. The coefficient of WVU educational sales and services per faculty ranges from 0.07 to 0.10 across all the four model specifications. The Spatial Panel Durbin Fixed Effects model has one of the highest values of the parameter estimate at 0.0982 signifying the magnitude of impact of university variable on total average industry wage. The coefficient suggests that a $1 \%$ increase in WVU educational sales and services per faculty results in $0.0982 \%$ increase in total average industry wage.

This result corresponds to the findings of Hausman (2012), stating that the spillover from university collaborations with local industries result in higher productivity and consequently an 
increase in industrial wages. The total effects are positive and significant for the impact of STEM industry earnings and local government productivity on total average industry wage. However, the indirect effects in general remain insignificant that seems to suggest the absence of spatial spillovers of all the explanatory variables on average industry wages.

The other control variables in the regression have similar characteristics as LSDV estimates depicted in Table 7. Therefore, they have similar interpretations. They are found to be fairly stable across all the specifications. The rho $(\rho)$ parameter remains statistically significant from Table 13 to Table 18 indicating strong spatial dependencies among the counties for the six economic development indicators.

In Table 15, the university variable, non-STEM R\&D expenditure per post doctorate student is found to have a positive impact on reducing poverty rate. The parameter estimates corresponding to this variable is fixed at 0.07 across all the three specifications. Similarly, in the Spatial Panel Durbin Fixed Effects model, non-STEM R\&D expenditure has a positive direct effect on poverty alleviation.

The rest of the control variables exhibit similar direct effects and are significance except in the case of federal government employment per capita. However, federal government employment per capita has a positive and significant indirect effect on reducing poverty. Hence, an increase in government employment per capita in a county has a positive spillover effect in terms of reducing the poverty rate in other counties by $0.08 \%$. The total effects are positive and significant for STEM industry earnings and federal government employment on decreasing poverty. The standard error of the estimates decreases moving from the LSDV estimates to Panel Fixed Effects and Panel SUR estimates. 
Table 14 Dependent Variable: Logarithm of Total Average Industry Wage

\begin{tabular}{|c|c|c|c|c|c|c|c|}
\hline Variable & LSDV & $\begin{array}{l}\text { Fixed } \\
\text { Effects }\end{array}$ & $\begin{array}{l}\text { Panel } \\
\text { SUR }\end{array}$ & $\begin{array}{c}\text { Spatial } \\
\text { Durbin } \\
\text { Fixed } \\
\text { Effects }\end{array}$ & $\begin{array}{c}\text { Spatial } \\
\text { Durbin } \\
\text { Direct } \\
\text { Effects }\end{array}$ & $\begin{array}{c}\text { Spatial } \\
\text { Durbin } \\
\text { Indirect } \\
\text { Effects }\end{array}$ & $\begin{array}{c}\text { Spatial } \\
\text { Durbin } \\
\text { Total } \\
\text { Effects }\end{array}$ \\
\hline $\begin{array}{l}\text { Log-WVU Educational Sales and Services } \\
\text { per Faculty }(U)\end{array}$ & $\begin{array}{l}0.10 * * \\
(0.04)\end{array}$ & $\begin{array}{l}0.08 * * \\
(0.01)\end{array}$ & $\begin{array}{l}0.07 * * \\
(0.01) \\
\end{array}$ & $\begin{array}{c}0.0981 * * \\
(0.03)\end{array}$ & $0.0982 * *$ & 0.0175 & 0.1158 \\
\hline Log -STEM Industry Earnings (I) & $\begin{array}{l}0.01 * * \\
(0.01)\end{array}$ & $\begin{array}{l}0.02 * * \\
(0.01)\end{array}$ & $\begin{array}{l}0.02 * * \\
(0.01)\end{array}$ & $\begin{array}{c}0.0923 * * \\
(0.01)\end{array}$ & $0.0925 * *$ & 0.0157 & $0.1081 * *$ \\
\hline Log- Violent Crime (C) & $\begin{array}{c}-0.04 * * \\
(0.01)\end{array}$ & $\begin{array}{c}-0.02 * * \\
(0.01)\end{array}$ & $\begin{array}{l}-0.01 * \\
(0.01)\end{array}$ & $\begin{array}{c}-0.0411 * * \\
(0.01)\end{array}$ & $-0.0409 * *$ & -0.0183 & -0.0591 \\
\hline $\begin{array}{l}\text { Metropolitan Statistical Area and Presence } \\
\text { of University Indicator (C) }\end{array}$ & $\begin{array}{l}0.02 * * \\
(0.01)\end{array}$ & - & - & - & - & - & - \\
\hline $\begin{array}{l}\text { Log- Ratio of Local Government Earnings to } \\
\text { Local Government Employment (G) }\end{array}$ & $\begin{array}{l}0.43 * * \\
(0.07)\end{array}$ & $\begin{array}{l}0.46^{* *} \\
(0.03)\end{array}$ & $\begin{array}{l}0.52 * * \\
(0.02)\end{array}$ & $\begin{array}{c}0.4148 * \\
(0.08)\end{array}$ & $0.4142 * *$ & 0.0644 & $0.4786^{*}$ \\
\hline Intercept & $\begin{array}{l}7.60 * \\
(0.23) \\
\end{array}$ & $\begin{array}{l}8.15^{*} \\
(0.12) \\
\end{array}$ & $\begin{array}{l}6.44^{*} \\
(0.10) \\
\end{array}$ & $\begin{array}{c}7.0707 * * \\
(0.94)\end{array}$ & - & - & - \\
\hline Spatial Autoregressive Lag Parameter $(\rho)$ & - & - & - & $\begin{array}{l}0.07 * \\
(0.01)\end{array}$ & - & - & - \\
\hline Observations & 385 & 385 & 385 & 385 & - & - & - \\
\hline Adjusted $\mathrm{R}^{2}$ & 0.51 & 0.49 & 0.50 & - & - & - & - \\
\hline F- Statistics/Chi-Square & $79.55 * *$ & $147.45 * *$ & $383.96 * *$ & - & - & - & - \\
\hline
\end{tabular}

Notes: Standard errors are provided in parentheses. Regression coefficients are rounded to nearest two decimal places. A single asterisk $(*)$ implies significance at 0.05 level in a two-tailed test. A double asterisk (**) implies significance at 0.01 level in a two tailed test. Dummy variables to control for time fixed effects are not reported here due space issues but are found to be significant in a two F-tailed test. F-Statistics is reported for LSDV and Fixed Effects Model where as ChiSquare statistics is reported for Panel SUR model. 
Table 15 Dependent Variable: Logarithm of Poverty Rate

\begin{tabular}{|c|c|c|c|c|c|c|c|}
\hline Variable & LSDV & $\begin{array}{l}\text { Fixed } \\
\text { Effects }\end{array}$ & $\begin{array}{l}\text { Panel } \\
\text { SUR }\end{array}$ & $\begin{array}{c}\text { Spatial } \\
\text { Durbin } \\
\text { Fixed } \\
\text { Effects }\end{array}$ & $\begin{array}{c}\text { Spatial } \\
\text { Durbin } \\
\text { Direct } \\
\text { Effects }\end{array}$ & $\begin{array}{c}\text { Spatial } \\
\text { Durbin } \\
\text { Indirect } \\
\text { Effects }\end{array}$ & $\begin{array}{c}\text { Spatial } \\
\text { Durbin } \\
\text { Total } \\
\text { Effects }\end{array}$ \\
\hline $\begin{array}{l}\text { Log-WVU Non-STEM R\&D Expenditure per Post } \\
\text { Doctorate Student (U) }\end{array}$ & $\begin{array}{c}-0.07 * * \\
(0.03)\end{array}$ & $\begin{array}{c}-0.07 * * \\
(0.01)\end{array}$ & $\begin{array}{l}-0.07^{*} \\
(0.01)\end{array}$ & $\begin{array}{c}-0.0625^{*} \\
(0.03)\end{array}$ & $-0.0626 * *$ & -0.0029 & -0.0654 \\
\hline Log -STEM Industry Earnings (I) & $\begin{array}{c}-0.04 * * \\
(0.01)\end{array}$ & $\begin{array}{c}-0.02^{* *} \\
(0.01)\end{array}$ & $\begin{array}{c}-0.02 * * \\
(0.01)\end{array}$ & $\begin{array}{c}-0.0634 * * \\
(0.01)\end{array}$ & $-0.0638 * *$ & -0.0133 & $-0.07 * *$ \\
\hline Metropolitan Statistical Area Indicator (C) & $\begin{array}{c}-0.20 * * \\
(0.03)\end{array}$ & - & - & - & - & - & - \\
\hline $\begin{array}{l}\text { Log- Federal Government Employment per capita } \\
\text { (G) }\end{array}$ & $\begin{array}{c}-0.03 * * \\
(0.02) \\
\end{array}$ & $\begin{array}{c}-0.02 * * \\
(0.01) \\
\end{array}$ & $\begin{array}{c}-0.02 * * \\
(0.01) \\
\end{array}$ & $\begin{array}{c}-0.0153^{*} \\
(0.01)\end{array}$ & -0.0179 & $-0.0813^{*}$ & $-0.0992 *$ \\
\hline Intercept & $\begin{array}{l}3.83^{*} \\
(0.20)\end{array}$ & $\begin{array}{l}3.02 * * \\
(0.18)\end{array}$ & $\begin{array}{l}2.87 * * \\
(0.16)\end{array}$ & $\begin{array}{l}3.1749^{* *} \\
(0.16)\end{array}$ & - & - & - \\
\hline Spatial Autoregressive Lag Parameter $(\rho)$ & - & - & - & $\begin{array}{r}0.26^{* *} \\
(0.05)\end{array}$ & - & - & - \\
\hline Observations & 385 & 385 & 385 & 385 & - & - & - \\
\hline Adjusted $\mathrm{R}^{2}$ & 0.21 & 0.25 & 0.21 & - & - & - & - \\
\hline F- Statistics/Chi-Square & $25.75 * *$ & $37.05 * *$ & $86.96 * *$ & - & - & - & - \\
\hline
\end{tabular}

Notes: Standard errors are provided in parentheses. Regression coefficients are rounded to nearest two decimal places. A single asterisk $(*)$ implies significance at 0.05 level in a two-tailed test. A double asterisk (**) implies significance at 0.01 level in a two tailed test. Dummy variables to control for time fixed effects are not reported here due space issues but are found to be significant in a two tailed F-test. F-Statistics is reported for LSDV and Fixed Effects Model whereas ChiSquare statistics is reported for Panel SUR model. 
Hence, for all the four models, an increase in university expenditure in R\&D results in poverty alleviation. Poverty is an important development indicator but so far past studies have overlooked its significance in similar researches. This research is an attempt to analyze the multidimensional role of university on poverty reduction.

A university's impact on public school enrollment has been overlooked in similar studies in the past literature. According to Barro (1989) public school enrollment is an important measure for initial stock of human capital in the economy. Thus, it is imperative to study whether university contributes to this initial stock of human capital in the local economy.

In Table 16, University grants per undergraduate student is found to have a positive and significant impact on public school enrollment per capita. This could be because one of the strategic goals of West Virginia University is to establish good networking channels with all the state public schools by providing them training and imparting technical knowledge. Therefore, resulting in the academic improvement of the public school system in West Virginia.

The coefficient corresponding to WVU grants per undergraduate student captures this aspect. That is, if there is an increase in grants per undergraduate student by $1 \%$ then the corresponding increase is about $0.11 \%$ in public school enrollment per capita based on the Spatial Durbin Fixed Effects Model. Consequently, the total effects of grants per undergraduate student is positive and significant on public school enrollment per capita. This effect is fairly stable across all the specifications. The coefficient ranges from 0.07 to 0.11 from the non-spatial to the spatial model. The control variables in the regression are stable and statistically significant across all the four models. They have the right signs and their interpretations are similar to the interpretation provided in Table 10. 
Table 16 Dependent Variable: Logarithm of Public School Enrollment Per Capita

\begin{tabular}{|c|c|c|c|c|c|c|c|}
\hline Variable & LSDV & $\begin{array}{l}\text { Fixed } \\
\text { Effects }\end{array}$ & $\begin{array}{l}\text { Panel } \\
\text { SUR }\end{array}$ & $\begin{array}{c}\text { Spatial } \\
\text { Durbin } \\
\text { Fixed } \\
\text { Effects }\end{array}$ & $\begin{array}{l}\text { Spatial } \\
\text { Durbin } \\
\text { Direct } \\
\text { Effects }\end{array}$ & $\begin{array}{l}\text { Spatial } \\
\text { Durbin } \\
\text { Indirect } \\
\text { Effects }\end{array}$ & $\begin{array}{c}\text { Spatial } \\
\text { Durbin } \\
\text { Total } \\
\text { Effects }\end{array}$ \\
\hline $\begin{array}{l}\text { Log-WVU Grants per } \\
\text { Undergraduate Student (U) }\end{array}$ & $\begin{array}{l}0.11 * * \\
(0.03)\end{array}$ & $\begin{array}{l}0.07 * * \\
(0.01)\end{array}$ & $\begin{array}{l}0.07 * * \\
(0.01)\end{array}$ & $\begin{array}{l}0.1082^{* *} \\
(0.03)\end{array}$ & $0.1113 * *$ & 0.1211 & $0.2324 *$ \\
\hline $\begin{array}{l}\text { Log - Ratio of STEM to NON } \\
\text { STEM Jobs in Industries (I) }\end{array}$ & $\begin{array}{l}0.03 * * \\
(0.01)\end{array}$ & $\begin{array}{l}0.01 * * \\
(0.01)\end{array}$ & $\begin{array}{l}0.01 * * \\
(0.01)\end{array}$ & $\begin{array}{c}0.0251^{* *} \\
(0.01)\end{array}$ & $0.0257^{*}$ & 0.0202 & 0.0459 \\
\hline Log- Violent Crime (C) & $\begin{array}{c}-0.02 * * \\
(0.01)\end{array}$ & $\begin{array}{c}-0.01 * * \\
(0.01)\end{array}$ & $\begin{array}{l}-0.01 * * \\
(0.01)\end{array}$ & $\begin{array}{c}-0.0156^{* *} \\
(0.01)\end{array}$ & $-0.0157 * *$ & -0.0037 & -0.0194 \\
\hline $\begin{array}{l}\text { Log- Federal Government } \\
\text { Expenditure per Federal } \\
\text { Employment }(\mathrm{G})\end{array}$ & $\begin{array}{l}0.03 * * \\
(0.01)\end{array}$ & $\begin{array}{l}0.02 * * \\
(0.01)\end{array}$ & $\begin{array}{c}0.01 * * \\
(0.01)\end{array}$ & $\begin{array}{l}0.0296^{* *} \\
(0.01)\end{array}$ & $0.0295 * *$ & -0.0053 & 0.0241 \\
\hline Intercept & $\begin{array}{l}2.39^{*} \\
(0.01)\end{array}$ & $\begin{array}{l}2.61 * \\
(0.08)\end{array}$ & $\begin{array}{l}1.97^{*} \\
(0.06)\end{array}$ & $\begin{array}{c}1.7268 * * \\
(0.21)\end{array}$ & - & - & - \\
\hline $\begin{array}{l}\text { Spatial Autoregressive Lag } \\
\text { Parameter }(\rho)\end{array}$ & - & - & - & $\begin{array}{c}0.20 * * \\
(0.01)\end{array}$ & - & - & - \\
\hline Observations & 385 & 385 & 385 & 385 & - & - & - \\
\hline Adjusted $\mathrm{R}^{2}$ & 0.13 & 0.14 & 0.14 & - & - & - & - \\
\hline F-Statistics/Chi-Square & $15.90 * *$ & $16.13 * *$ & $55.77 * *$ & - & - & - & - \\
\hline
\end{tabular}

Notes: Standard errors are provided in parentheses. Regression coefficients are rounded to nearest two decimal places. A single asterisk $(*)$ implies significance at 0.05 level in a two-tailed test. A double asterisk $(* *)$ implies significance at 0.01 level in a two tailed test. Dummy variables to control for time fixed effects are not reported here due space issues but are found to be significant in a two tailed F-test. F-Statistics is reported for LSDV and Fixed Effects Model where as ChiSquare statistics is reported for Panel SUR model. 
Table 17 Dependent Variable: Logarithm of Industrial Earnings per Industrial Units

\begin{tabular}{|c|c|c|c|c|c|c|c|}
\hline Variable & LSDV & $\begin{array}{l}\text { Fixed } \\
\text { Effects }\end{array}$ & $\begin{array}{l}\text { Panel } \\
\text { SUR }\end{array}$ & $\begin{array}{l}\text { Spatial } \\
\text { Durbin } \\
\text { Fixed } \\
\text { Effects }\end{array}$ & $\begin{array}{l}\text { Spatial } \\
\text { Durbin } \\
\text { Direct } \\
\text { Effects }\end{array}$ & $\begin{array}{l}\text { Spatial } \\
\text { Durbin } \\
\text { Indirect } \\
\text { Effects }\end{array}$ & $\begin{array}{c}\text { Spatial } \\
\text { Durbin } \\
\text { Total } \\
\text { Effects }\end{array}$ \\
\hline $\begin{array}{l}\text { Log-WVU Educational Sales } \\
\text { Services per Graduate Student (U) }\end{array}$ & $\begin{array}{l}0.14^{* *} \\
(0.05)\end{array}$ & $\begin{array}{l}0.09 * * \\
(0.02)\end{array}$ & $\begin{array}{l}0.11 * * \\
(0.02)\end{array}$ & $\begin{array}{c}0.1259^{* *} \\
(0.05)\end{array}$ & $0.1221 * *$ & 0.1488 & 0.2709 \\
\hline $\begin{array}{l}\text { Log -Industrial Units with less than } \\
10,000 \text { workers (I) }\end{array}$ & $\begin{array}{l}-0.60^{* *} \\
(0.03)\end{array}$ & $\begin{array}{l}-0.54 * * \\
(0.03)\end{array}$ & $\begin{array}{c}-0.52^{* *} \\
(0.01)\end{array}$ & $\begin{array}{c}-0.6101 * * \\
(0.03)\end{array}$ & $-0.6124 * *$ & -0.0923 & $-0.7047 * *$ \\
\hline Log- Educational Service Jobs (I) & $\begin{array}{l}0.01 * * \\
(0.01)\end{array}$ & $\begin{array}{l}0.02 * * \\
(0.01)\end{array}$ & $\begin{array}{l}0.01 * * \\
(0.01)\end{array}$ & $\begin{array}{c}0.0066^{* *} \\
(0.01)\end{array}$ & $0.0069^{*}$ & 0.0123 & $0.0193 *$ \\
\hline $\begin{array}{l}\text { Log- Ratio of STEM to Non-STEM } \\
\text { Average Wages (I) }\end{array}$ & $\begin{array}{l}0.07 * * \\
(0.01)\end{array}$ & $\begin{array}{l}0.07 * * \\
(0.01)\end{array}$ & $\begin{array}{l}0.05 * * \\
(0.01)\end{array}$ & $\begin{array}{l}0.0731^{* *} \\
(0.01)\end{array}$ & $0.0714 * *$ & $0.0666^{*}$ & 0.1380 \\
\hline $\begin{array}{l}\text { Log- Share of Hi-Tech Employment } \\
\text { (I) }\end{array}$ & $\begin{array}{l}0.08^{* *} \\
(0.02)\end{array}$ & $\begin{array}{l}0.10^{* *} \\
(0.02)\end{array}$ & $\begin{array}{l}0.10 * * \\
(0.02)\end{array}$ & $\begin{array}{c}0.0829 * * \\
(0.02)\end{array}$ & $0.0823 * *$ & 0.0235 & 0.1057 \\
\hline $\begin{array}{l}\text { Metropolitan Statistical Area } \\
\text { Indicator }(\mathrm{C})\end{array}$ & $\begin{array}{l}0.08^{* *} \\
(0.02)\end{array}$ & - & - & - & - & - & - \\
\hline $\begin{array}{l}\text { Log - Ratio of Local Government } \\
\text { Earning to Local Government } \\
\text { Employment }(\mathrm{G})\end{array}$ & $\begin{array}{l}0.42 * * \\
(0.10)\end{array}$ & $\begin{array}{l}0.56^{* *} \\
(0.06)\end{array}$ & $\begin{array}{l}0.56^{* *} \\
(0.04)\end{array}$ & $\begin{array}{l}0.4444 * * \\
(0.10)\end{array}$ & $0.4521 * *$ & 0.3034 & $0.7554 *$ \\
\hline Intercept & $\begin{array}{l}8.02 * \\
(0.40)\end{array}$ & $\begin{array}{l}5.71 * \\
(0.34)\end{array}$ & $\begin{array}{l}4.96^{*} \\
(0.32)\end{array}$ & $\begin{array}{c}6.3630^{*} \\
(1.29)\end{array}$ & - & - & - \\
\hline $\begin{array}{l}\text { Spatial Autoregressive Lag Parameter } \\
\text { ( } \rho)\end{array}$ & - & - & - & $\begin{array}{l}0.20 * * \\
(0.05)\end{array}$ & - & - & - \\
\hline Observations & 385 & 385 & 385 & 385 & - & - & - \\
\hline Adjusted $\mathrm{R}^{2}$ & 0.73 & 0.75 & 0.71 & - & - & - & - \\
\hline F- Statistics/Chi-Square & $150.53 * *$ & $166.67 * *$ & $1010.63 * *$ & - & - & - & - \\
\hline
\end{tabular}

Notes: Standard errors are provided in parentheses. Regression coefficients are rounded to nearest two decimal places. A single asterisk $\left({ }^{*}\right)$ implies significance at 0.05 level in a two-tailed test. A double asterisk $(* *)$ implies significance at 0.01 level in a two tailed test. Dummy variables to control for time fixed effects are not reported here due space issues but are found to be significant in a two F-tailed test. F-Statistics is reported for LSDV and Fixed Effects Model where as ChiSquare statistics is reported for Panel SUR model. 
Table 17 captures the impact of university characteristics on the dependent variable industrial earnings per industrial unit. The university variable WVU Educational Sales Services per Graduate Student is found to have a positive and statistically significant impact on industrial productivity across all the specifications. In the Spatial Durbin Fixed Effects Model, a 1\% increase in educational sales services per graduate student results in $0.12 \%$ increase in industrial earnings per industrial unit. Moreover, the ratio of STEM to non-STEM wages has a positive indirect effect on industrial earnings per unit. This result signifies the importance of the spillover effect from the ratio of STEM to non-STEM wages of a county on the local industrial earnings per industrial unit of other counties. The effect of educational sales and services per graduate student is found to be less strong in non-spatial models but significant nonetheless.

The last development indicator is the creation of patents per STEM industrial unit. The LSDV estimation results for this dependent variable has been reported in Table 12. Table 18 compares the LSDV estimates with Fixed Effects, Panel SUR and Spatial Panel Durbin Fixed Effects models. After controlling for spatial autocorrelation in a Spatial Durbin Fixed Effects Model, the impact of university STEM federal grants per undergraduate student has a positive and significant direct and total effect on patent creation per STEM industrial unit keeping other variables fixed. The coefficient suggests that keeping other factors fixed, a $\$ 1,000$ increase in STEM federal grants per undergraduate student results in approximately 7 patent creation per STEM industrial unit. However, no evidence of indirect effect is found for this indicator. 
Table 18 Dependent Variable: Patents per STEM Industrial Unit

\begin{tabular}{|c|c|c|c|c|c|c|c|}
\hline Variable & LSDV & $\begin{array}{l}\text { Fixed } \\
\text { Effects }\end{array}$ & $\begin{array}{l}\text { Panel } \\
\text { SUR }\end{array}$ & $\begin{array}{c}\text { Spatial } \\
\text { Durbin } \\
\text { Fixed } \\
\text { Effects }\end{array}$ & $\begin{array}{l}\text { Spatial } \\
\text { Durbin } \\
\text { Direct } \\
\text { Effects }\end{array}$ & $\begin{array}{l}\text { Spatial } \\
\text { Durbin } \\
\text { Indirect } \\
\text { Effects }\end{array}$ & $\begin{array}{c}\text { Spatial } \\
\text { Durbin } \\
\text { Total } \\
\text { Effects }\end{array}$ \\
\hline $\begin{array}{l}\text { WVU Ratio STEM Grants per } \\
\text { Undergraduate Student (U) }\end{array}$ & $\begin{array}{l}0.008 * * \\
(0.002)\end{array}$ & $\begin{array}{l}0.006^{* *} \\
(0.002)\end{array}$ & $\begin{array}{l}0.007 * * \\
(0.001)\end{array}$ & $\begin{array}{c}0.0074 * * \\
(0.002)\end{array}$ & $0.0074 * *$ & 0.0036 & $0.0110^{*}$ \\
\hline $\begin{array}{l}\text { Manufacturing Sector Average } \\
\text { Wage (I) }\end{array}$ & $\begin{array}{l}0.001 * * \\
(0.001)\end{array}$ & $\begin{array}{l}0.001 * * \\
(0.001)\end{array}$ & $\begin{array}{l}0.001 * * \\
(0.001)\end{array}$ & $\begin{array}{c}0.0001 * * \\
(0.001)\end{array}$ & $0.0001 * *$ & 0.0001 & 0.0002 \\
\hline Mining Sector Average Wage (I) & $\begin{array}{l}0.001 * * \\
(0.001)\end{array}$ & $\begin{array}{l}0.001 * * \\
(0.001)\end{array}$ & $\begin{array}{l}0.001 * * \\
(0.001)\end{array}$ & $\begin{array}{c}0.0001^{* *} \\
(0.001)\end{array}$ & $0.0001 * *$ & 0.0001 & 0.0002 \\
\hline $\begin{array}{l}\text { Metropolitan Statistical Area and } \\
\text { Presence of University Indicator } \\
\text { (C) }\end{array}$ & $\begin{array}{l}0.005 * * \\
(0.001)\end{array}$ & - & - & - & - & - & - \\
\hline $\begin{array}{l}\text { Ratio of Federal Government } \\
\text { Expenditure to Federal } \\
\text { Government Employment }(\mathrm{G})\end{array}$ & $\begin{array}{c}0.001 \\
(0.001)\end{array}$ & $\begin{array}{c}0.001 \\
(0.001)\end{array}$ & $\begin{array}{c}0.001 \\
(0.001)\end{array}$ & $\begin{array}{l}0.0001 \\
(0.001)\end{array}$ & 0.0001 & 0.001 & 0.002 \\
\hline Intercept & $\begin{array}{l}-0.016^{*} \\
(0.005)\end{array}$ & $\begin{array}{l}-0.005 \\
(0.003)\end{array}$ & $\begin{array}{l}-0.002 \\
(0.001)\end{array}$ & $\begin{array}{l}-0.0200 \\
(0.001)\end{array}$ & - & - & - \\
\hline $\begin{array}{l}\text { Spatial Autoregressive Lag } \\
\text { Parameter }(\rho)\end{array}$ & - & - & - & $\begin{array}{l}0.25^{*} \\
(0.03)\end{array}$ & - & - & - \\
\hline Observations & 385 & 385 & 385 & 385 & - & - & - \\
\hline Adjusted $\mathrm{R}^{2}$ & 0.09 & 0.09 & 0.10 & - & - & - & - \\
\hline F- Statistics/Chi-Square & $8.77 * *$ & $9.45 * *$ & $41.33 * *$ & - & - & - & - \\
\hline
\end{tabular}

Notes: Standard errors are provided in parentheses. Regression coefficients are rounded to nearest three decimal places. A single asterisk $(*)$ implies significance at 0.05 level in a two-tailed test. A double asterisk $\left(^{* *}\right.$ implies significance at 0.01 level in a two tailed test. Dummy variables to control for time fixed effects are not reported here due space issues but are found to be significant in a two tailed F-test. F-Statistics is reported for LSDV and Fixed Effects Model where as ChiSquare statistics is reported for Panel SUR model. 
Similarly, in the non-spatial models, the regression coefficient for this variable is around the same vicinity and are statistically significant. However, the coefficient for Federal Government productivity measure remains insignificant across the different models. The results concur to the findings of some of the contemporary studies by Jaffe (1989), Andersson et al. (2009), Woodward et al. (2006).

All the other coefficients representing the control variables from industry, community and government are found to have the right signs and are also statistically significant except for the government variable both in the spatial and the non-spatial models. The interpretation of these coefficients are analogous to the interpretations provided in Table 12. The normality of residuals is tested for all the regression models using Shapiro-Wilk and Jarque-Bera Tests. The test results are reported in the Result Appendix. Based on the results from this analysis, the findings of this research are concluded in the next section.

\section{Chapter 6. SUMMARY and CONCLUSION}

\subsection{Summary}

This research performs an in depth study of the existing scholarly literature, defines the research hypotheses, develops a theoretical model and estimates empirical models to show that West Virginia University has a positive and significant impact on the economic development of West Virginia. More specifically, six development indicators are identified namely, income per capita, total average industry wages, poverty rate, public school enrollment per capita, industry earnings per industrial unit and patents per STEM industrial unit. The study identifies and assesses university characteristics that directly impact local area development such as availability of 
faculty, staff, graduate, undergraduate, STEM, Non-STEM students, grants, recurring expenditure, consulting services, income from sponsorship and sporting events. The econometric models estimated in this study are consistent in terms of indicating the positive impact of West Virginia University on the state of West Virginia.

Additionally, indirect channels such as collaboration of WVU with local industries for joint research and patent creation, encouraging local entrepreneurship and establishment of hi-tech infrastructure are identified as mechanisms that translates into greater economic growth and sustainable economic development. WVU strengthens the local primary and secondary education systems by disseminating knowledge from the university to the state education organizations that indirectly translates into local area development and growth. Moreover, university provides adequate infrastructure, technical guidance and knowledge to the local community and industries that fosters innovation and technical progress.

West Virginia is a state where chemical, biotech, energy, aerospace and automobile are major industries. All these industries fall under the STEM category. The summary statistics presented in this research paper suggests that most of the jobs created in West Virginia's industrial sector are driven by STEM industries. On an average, STEM jobs earn four times more wages compared to non-STEM jobs in West Virginia. Moreover, a number of industrial firms in West Virginia specialize in providing educational services in addition to the research and development conducted by West Virginia University. Collaboration of WVU with local industries for joint research and development through educational sales and services by educational departments and STEM research expenditure have a positive influence on patent creation, industrial wages and earnings that translates into greater economic and industrial growth in the area. 
The local community also experiences similar spillover benefits from the university in terms of poverty alleviation, higher per capita income and public school enrollment due to the presence of hi-tech human capital in the area and general investments and expenditure on development. These spillovers induce economic development in the region. WVU strengthens the local primary and secondary education system by using its stock of human capital for training purposes and investment in capital assets for developing necessary educational infrastructure that results in an overall improvement in the state school system and promote public school enrollment in the state.

Location of another subsidiary university or school in a metropolitan statistical area (MSA) reinforces development as MSAs have better infrastructure and higher job opportunities compared to other areas. On a similar note, federal, state and local government play vital roles in economic development by supporting and strengthening the impacts of university, industry and community. Government gets benefitted in terms of higher tax revenue when there is an increase in employment, innovation and rapid industrialization in the region. Increase in tax revenue stimulates the government to invest further in the community that results in greater sustainable economic development and growth in the local area.

This study identifies and recognizes the roles of these important entities on local area development and growth. Moreover, their impact is collectively assessed using a regression framework on the six development indicators. The LSDV, Fixed Effects, Panel SUR and Spatial Panel Durbin Fixed Effects models in unison find evidence of positive and significant role of university on local area development while controlling for the influence of local industry, community and government. The estimates across all the models suggest that university faculty, STEM graduate and post doctorate students, recurring expenditure and grants have significant 
impact on local area development. Since university replenishes its stock of faculty and students every year, there is a constant pool of human capital which provides positive spillover effect to the local community resulting in a sustainable long-term economic development.

\subsection{Conclusion and Policy Implications}

The empirical analysis identifies the types of university activities that generate positive spillovers on the economy. The results interpreted may additionally be used by state leaders and the university in developing important economic policies for the state.

West Virginia University has a positive impact on the first development indicator, income per capita. The empirical results find an increase in West Virginia University's STEM research and development per faculty, recurring expenditures per tenured faculty and educational consultancy services provided per graduate student result in higher income per capita at the county level.

Therefore, universities may allocate more funds to STEM research and development and promote the sales and services of educational products by further commercializing university research with the local industry. Consequently, government should increase funding for STEM research and development. Moreover, expenditures on tenured faculty in terms of salaries and other recurring expenses should be treated as a perpetual investment on the economy that raises the overall income of the population. The government must provide positive economic initiatives for universities and industries to collaborate on similar research ventures.

The second economic indicator, average wages in industries increases with the number of post-doctoral students, consultancy services by educational departments and the recurring expenditures incurred by West Virginia University. 
Consequently, the university must increase employment of high quality labor like STEM post-doctoral students. Also, the government must support the hiring of high-tech workers and develop linkages with industries to retain STEM human capital to sustain higher industrial wages that reflects greater productivity and education among workers in the economy.

The third development indicator, poverty rate lowers in the presence of additional graduate students and in case of higher non-STEM research and development expenditure per post doctorate student incurred in non-stem fields like social sciences etc.

Non-STEM expenditures incurred have a positive effect on the economy by driving down the poverty rate. Consequently, the government must give adequate importance to non-STEM research expenditures and prioritize these expenditures when making budgetary decisions.

West Virginia University has a positive impact on the fourth economic indicator, public school enrollment per capita. The empirical results find an increase in West Virginia University's grants per undergraduate student, recurring expenditure per post doctorate student and capital asset investments per doctoral student result in higher public school enrollment. Since, one of the primary goals of West Virginia University is to collaborate with the pre $\mathrm{K}-12$ education system and the local community, an increase in grants per undergraduate student provides support to such collaborations that eventually translates into an upsurge in public school enrollment. Additionally, recurring expenditures and investment in capital assets provide infrastructural support to conduct seminars and training to technical colleges throughout the state (another goal of West Virginia University) reinforcing the spillover effect on public school enrollment. The government can collaborate with universities and use these channels to maintain and increase public school enrollment in the economy. 
The fifth development indicator, industrial earnings per industrial unit increases with an expansion in West Virginia University's educational sales and services and auxiliary fees. The auxiliary fees include revenue from sales of sporting events through private business enterprise sponsorships and transportation services.

This finding supports the importance of university and industry collaborations on industrial productivity. Accordingly, the government must provide suitable incentives for more collaborations between the university and industry. Since such collaborations produce higher industrial productivity and earnings in the area promoting local area employment and the establishment of new startups in the economy.

West Virginia University has a positive impact on the last economic indicator, patents per STEM industrial unit. The empirical models find an increase in West Virginia University's STEM grants (federal and state), non-STEM research and development expenditures and STEM graduate students result in the creation of new patents in STEM industries.

Thus, it is imperative to incur greater expenditure on STEM research and development to have advanced innovations in terms of new patent creation. Utility patents are issued on invention of new process, machine and manufacturing or improvements on existing technology (United States Patent and Trademark Office, 1999). West Virginia has a concentration of STEM industries specializing in processes, machines and manufacturing. Therefore, it is crucial for the government to prioritize investments in STEM research and development in way of grants to all the universities in West Virginia. Furthermore, provide additional support to universities in hiring STEM graduate students to sustain innovations in the state.

The results from this research suggest that university plays a multi-dimensional role in the local area development. It not only has a direct impact but also an indirect effect through different 
channels in the form of collaboration with community, industry and government. Investment in high quality labor, infrastructure, hi-tech industry and STEM jobs are pillars for sustainable and long-term economic development in West Virginia. Therefore, further investment in university and commercialization of university research is warranted for regional development in West Virginia.

\subsection{Future Research}

This research is a first attempt to estimate the impact of a university on local area development employing micro level county data in a panel data set up. The study adds to the existing body of knowledge by providing a rigorous framework outlining a theoretical and econometric models to analyze the impact of a university on local area development and growth.

Future research in this area will include extending the panel data for more years once the data becomes available. A larger panel will provide more realistic estimates of the impact of West Virginia University on local area development over a short and longer time horizon. Availability of a longer time series and a suitable university policy change will provide more scope to employ other techniques such as the county matching principle (Liu, 2014).

West Virginia University is the primary research university in the state of West Virginia. Therefore, this study is limited to the role of one research university on the local economic development and growth of a region. However, in most of the other states of the United States, there are multiple leading research universities. In such a situation, this analysis can be employed with suitable modifications to identify, isolate and capture the interaction effects of the universities on local area development and growth. 
This dissertation measures the impact of West Virginia University on the economic development indicators for the state of West Virginia. However, this study can be extended to analyze the impact of a university on non-economic indicators that improve the quality of life in an area such as performances or number of events being organized in the university in a given year.

Lastly, with further statistical software advancement the analysis in this research may be extended to a spatial panel SUR model which will provide more efficient and consistent estimates of the panel SUR models. 


\section{REFERENCES}

Acs, Z. J., Audretsch, D. B., \& Feldman, M. P. (1992). "Real Effects of Academic Research: Comment." The American Economic Review, 82(1), 363-367.

Aghion, P., Boustan, L., Hoxby, C., \& Vandenbussche, J. (2009). “The Causal Impact of Education on Economic Growth: Evidence from US.” Harvard University.

Andersson, R., Quigley, J. M., \& Wilhelmson, M. (2004). "University Decentralization as Regional Policy: The Swedish Experiment.” Journal of Economic Geography, 4(4), 371-388.

Andersson, R., Quigley, J. M., \& Wilhelmsson, M. (2009). "Urbanization, Productivity, and Innovation: Evidence from Investment in Higher Education.” Journal of Urban Economics, 66(1), 2-15.

Anselin, L. (1988). Spatial Econometrics: Methods and Models. Kluwer Academic. Boston, MA.

Anselin, L., Bera, A. K., Florax, R., \& Yoon, M. J. (1996). "Simple Diagnostic Tests for Spatial Dependence.” Regional Science and Urban Economics, 26(1), 77-104.

Anselin, L. \& Varga, A. \& Acs, Z. (1997). "Local Geographic Spillovers between University Research and High Technology Innovations." Journal of Urban Economics, Elsevier, 42(3), 422448.

Anselin, L. (2000). "Geographical Spillovers and University Research: A Spatial Econometric Perspective." Growth and Change, 31(4),501-515.

http://EconPapers.repec.org/RePEc:bla:growch:v:31:y:2000:i:4:p:501-515.

Anselin, L., Le Gallo, J., \& Jayet, H. (2008). “Spatial Panel Econometrics.” The Econometrics of Panel Data. Springer Berlin Heidelberg. 625-660.

Arcidiacono, P. (2004). “Ability Sorting and the Returns to College Major.” Journal of Econometrics, 121(1), 343-375.

Audretsch, D. B., \& Stephan, P. E. (1996). Company-Scientist Locational Links: The Case of Biotechnology. The American Economic Review, 86(3), 641-652.

Audretsch, D. B., \& Feldman, M. P. (1996). "R\&D Spillovers and the Geography of Innovation and Production." The American Economic Review, 86(3), 630-640.

Audretsch, D. B., \& Lehmann, E. E. (2005). "Does the Knowledge Spillover Theory of Entrepreneurship Hold for Regions?.” Research Policy, 34(8), 1191-1202. 
Bacheller, J. M. (2000). "Commentary on State-Level Economic Development in New York: A Strategy to Enhance Effectiveness." Economic Development Quarterly, 14(1), 5-10.

Baltagi, B. H. (2011). "Spatial Panels.” Handbook of Empirical Economics and Finance. Chapman \& Hall: London. 435-454.

Bania, N., Eberts, R. W., \& Fogarty, M. S. (1993). "Universities and the Startup of New Companies: Can we Generalize from Route 128 and Silicon Valley?." Review of Economics and Statistics, 75(4), 761-766.

Barro, R. J. (1989). "Economic Growth in a Cross Section of Countries.” (No. w3120). National Bureau of Economic Research.

Besson, P., \& Montgomery, E. (1993). “The Effect of College and Universities on Local Labor Markets." Review of Economics and Statistics, 75(4), 753-61.

Biørn, E. (2004). "Regression Systems for Unbalanced Panel Data: A Stepwise Maximum Likelihood Procedure." Journal of Econometrics, 122(2), 281-291.

Breusch, T. S., \& Pagan, A. R. (1979). “A Simple Test for Heteroscedasticity and Random Coefficient Variation.” Econometrica, 47, 1287-1294.

Cameron, A. C., \& Trivedi, P. K. (2005). Microeconometrics: Methods and Applications. Cambridge University Press.

Carnegie Foundation for the Advancement of Teaching. (2015). "Carnegie Classification of Institutions of Higher Education." http://carnegieclassifications.iu.edu/. Accessed, October, 2015.

Chamberlain, G. (1978). "Omitted Variable Bias in Panel Data: Estimating the Returns to Schooling." In Annales de l'INSEE. Institut National de la Statistique et des études économiques. 49-82.

Cohen, W. M., Nelson, R. R., \& Walsh, J. P. (2002). "Links and Impacts: The Influence of Public Research on Industrial R\&D.” Management Science, 48(1), 1-23.

Das, D., Kelejian, H. H., \& Prucha, I. R. (2003). "Finite Sample Properties of Estimators of Spatial Autoregressive Models with Autoregressive Disturbances.” Papers in Regional Science, 82(1), 1-26.

Department of Homeland Security (2011). "Study in The States." http://studyinthestates.dhs.gov/2011/09/what-does-stem-stand-for. Accessed, December 2014.

Dickey, D. A., \& Fuller, W. A. (1979). "Distribution of the Estimators for Autoregressive Time Series with a Unit Root.” Journal of the American Statistical Association, 74(366a), 427-431. 
Elhorst, J. P. (2003). "Specification and Estimation of Spatial Panel Data Models." International Regional Science Review, 26(3), 244-268.

Elhorst, J. P. (2010). “Applied Spatial Econometrics: Raising the Bar." Spatial Economic Analysis, 5(1), 9-28.

Fischer, M. M., \& Attila, V. (2003). "Spatial Knowledge Spillovers and University Research: Evidence from Austria." The Annals of Regional Science, Springer. 37(2), 303-322.

Florida, R., \& Cohen, W. (1999). "Engine or Infrastructure? The University Role in Economic Development." L. Branscomb, F. Kodama, \& R. Florida (Ed.), Industrializing Knowledge. 589610.

Greene, W. H. (2003). Econometric Analysis. Pearson Education India.

Glaeser, E. L., \& Maré, D. C. (2001). “Cities and Skills,” Journal of Labor Economics, 19(2), 316-342.

Hausman, J. A. (1978). "Specification Tests in Econometrics." Econometrica, 46(6), 1251-1271.

Hausman, J. A., \& Taylor, W. E. (1981). "Panel Data and Unobservable Individual Effects." Econometrica, 49(6), 1377-1398.

Hausman, N. (2012), "University Innovation, Local Economic Growth, and Entrepreneurship". US Census Bureau Center for Economic Studies Paper No. CES-WP- 12-10.

Hoffman D., \& Hill, K. (2009). "The Contribution of Universities to Regional Economies", Arizona State University Press.

Hume, David (1948). Moral and Political Philosophy. New York, Hafner Pub. Co.

Inzelt, A. (2004). "The Evolution of University-Industry-Government Relationships during Transition." Research Policy, 33(6-7), 975-995.

Jaffe, A. B. (1989). "Real Effects of Academic Research.” The American Economic Review, 79(5), 957-970

Jarque, C. M., \& Bera, A. K. (1980). "Efficient Tests for Normality, Homoscedasticity and Serial Independence of Regression Residuals." Economics Letters, 6(3), 255-259.

Kantor, S., \& Whalley, A. (2009). "Do Universities Generate Agglomeration Spillovers? Evidence from Endowment Value Shocks." (No. w15299). National Bureau of Economic Research. 
Kelejian, H. H., \& Prucha, I. R. (1999). “A Generalized Moments Estimator for the Autoregressive Parameter in a Spatial Model.” International Economic Review, 40(2), 509-533. doi: 10.1111/1468-2354.00027.

Langdon, D., McKittrick, G., Beede, D., Khan, B., \& Doms, M. (2011). "STEM: Good Jobs Now and for the Future." U.S. Department of Commerce.

LeSage, J. P., \& Pace, R. K. (2010). "Spatial Econometric Models.” M. M. Fischer \& A. Getis(Ed.), Handbook of Applied Spatial Analysis. Springer Berlin Heidelberg. 355-376.

Leslie, L.L., \& Slaughter, S.A. (1992). "Higher Education and Regional Development.” F. Welch \& E Hanushek (Ed.), The Economics of American Higher Education. Dordecht: Klewer Academic Publishers.

Lin, J. Y., \& Nugent, J. B. (1995). "Institutions and Economic Development." J. Behrman \& T.N. Srinivasan (Ed.), Handbook of Development Economics, 3(a), 2301-2370.

Liu, N. C., \& Cheng, Y. (2005). "The Academic Ranking of World Universities.” Higher Education in Europe, 30(2), 127-136.

Liu, S. (2014). “Agglomeration Economies, Investment in Education, and Regional Development.” Dissertations - ALL. Paper 94. Syracuse University. http://surface.syr.edu/etd/94.

Lucas, R. E. Jr. (1988). "On the Mechanics of Economic Development," Journal of Monetary Economics, 22(1), 3-42.

Mill, J. S. (1848). "Principles of Political Economy with some of their Applications to Social Philosophy." 1857. New Edition introduced by Sir WJ Ashley. London.

Millo, G., \& Piras, G. (2012). "Splm: Spatial Panel Data Models in R.” Journal of Statistical Software, 47(1), 1-38.

Moran, P. A. (1950). “Notes on Continuous Stochastic Phenomena.” Biometrika, 37(1/2), 17-23.

Moretti, E. (2004). "Workers' Education, Spillovers, and Productivity: Evidence from PlantLevel Production Functions.” The American Economic Review, 94(3), 656-690.

National Science Foundation (2007). "Division of Science Resources Statistics." Survey of Industrial Research and Development. http://www.nsf.gov/statistics/srvyindustry/\#tabs-2. Accessed, August, 2015.

National Science Foundation (2007). "Division of Science Resources Statistics." Survey of Research and Development Expenditures at Universities and Colleges. http://www.nsf.gov/statistics/srvyfedsupport/\#sd. Accessed, August, 2015. 
Porter, M. E. (2000). "Location, Competition, and Economic Development: Local Clusters in a Global Economy." Economic Development Quarterly, 14(1), 15-34.

Rey, S. J., \& Montouri, B. D. (1999). “US Regional Income Convergence: A Spatial Econometric Perspective.” Regional Studies, 33(2), 143-156.

Romer, P. M. (1990). "Endogenous Technological Change." Journal of Political Economy, 98(5), S71-S102.

Rodrik, D., Subramanian, A., \& Trebbi, F. (2004). "Institutions Rule: The Primacy of Institutions over Geography and Integration in Economic Development." Journal of Economic Growth, 9(2), 131-165.

Rosenthal, S. S., \& Strange, W. C. (2008). "The Attenuation of Human Capital Spillovers." Journal of Urban Economics, 64(2), 373-389.

Schultz, T. W. (1961). "Investment in Human Capital.” The American Economic Review, 51(1), $1-17$.

Shapiro, S. S., \& Wilk, M. B. (1965). "An Analysis of Variance Test for Normality (Complete Samples).” Biometrika, 52(3/4), 591-611.

Siegfried, J. J., Sanderson, A. R., \& McHenry, P. (2007). "The Economic Impact of Colleges and Universities." Economics of Education Review. 26(5), 546-558.

Smith, A. (1937). The Wealth of Nations. The Modern Library. Random House, Inc. 421.

Sohn, D.W., \& Kenney, M. (2007). "Universities, Clusters, and Innovation Systems: The Case of Seoul, Korea." World Development, 35(6), 991-1004.

Swenson, D. (2007). "Measuring University Contributions to Regional Economies: A Discussion of Guidelines for Enhancing Credibility." Economics of Education Review. 26(5), 546-558.

The Great Divergence. (2016). The Economist. http://www.economist.com/news/unitedstates/21694356-inequality-between-states-has-risen-most-past-15-years-americas-mostsuccessful-cities. Accessed, March, 2016.

United States Bureau of Labor Statistics (2015), "Quarterly Census of Employment \& Wages." statsamerica.org. Accessed, July, 2015.

United States Department of Education (2015), "Institute of Education Sciences." National Center for Education Statistics. http://nces.ed.gov/collegenavigator/. Accessed, May, 2015.

United States Census Bureau (2015). "Economic Census." USA Counties. http://censtats.census.gov/usa/usa.shtml. Accessed, June, 2015. 
United States Census Bureau (2015). "Topologically Integrated Geographic Encoding and Referencing." WV Counties. http://www.census.gov/geo/maps-data/data/tiger.html. Accessed, March, 2014.

U.S. Patent and Trademark Office (1999). "Grants by State, County, and Metropolitan Area." Utility Patents. http://www.uspto.gov/web/offices/ac/ido/oeip/taf/reports.htm. Accessed, June, 2015.

Vandegrift, D., Lockshiss, A., \& Lahr, M. (2012). "Town versus Gown: The Effect of a College on Housing Prices and the Tax Base". Growth and Change, 43(2), 304-334.

Varga, A. (2000). "Local Academic Knowledge Transfers and the Concentration of Economic Activity." Journal of Regional Science, 40(2), 289-309.

West Virginia Department of Commerce (2016). "Business and Workforce.” West Virginia Industries. http://www.wvcommerce.org/business/industries/default.aspx. Accessed, January, 2016.

West Virginia University (2007). "Planning and Treasury Operations.” Institutional Report. http://planning.wvu.edu/institutional_research. Accessed, May, 2015.

West Virginia University (2007). "Office of the Vice President for Administration and Finance." Reports and Presentations. http://adminfin.wvu.edu/reports. Accessed, May, 2015.

West Virginia University (2015). "Strategic Plan for the Future." http://strategicplan.wvu.edu. Accessed, March, 2014.

Wood, F. (1990). "Factors Influencing Research Performance of University Academic Staff." Higher Education, 19(1), 81-100.

Woodward, D., Figueiredo, O., \& Guimaraes, P. (2006). "Beyond the Silicon Valley: University R\&D and Hightechnology Location." Journal of Urban Economics, 60(1), 15-32.

Zellner, A. (1962). "An Efficient Method of Estimating Seemingly Unrelated Regressions and Tests for Aggregation Bias." Journal of the American Statistical Association, 57(298), 348-368. 


\section{APPENDIX}

Data Appendix

\section{Table DA1: Data Sources and Description for Income per Capita Model}

\begin{tabular}{|c|c|c|}
\hline Variable Names & Description & Sources \\
\hline \multicolumn{3}{|l|}{ Dependent Variable : } \\
\hline Income per capita & Income Per Capita & U.S. Census Bureau, Bureau of Economic Analysis \\
\hline \multicolumn{3}{|l|}{ Independent Variables : } \\
\hline \multicolumn{3}{|l|}{ University Variables } \\
\hline \multirow[t]{2}{*}{$\begin{array}{l}\text { WVU STEM Research and Development } \\
\text { Expenditure per Faculty }\end{array}$} & $\begin{array}{l}\text { STEM Research and Development } \\
\text { Expenditure }\end{array}$ & $\begin{array}{l}\text { National Science Foundation, National Center for Science and Engineering Statistics, Higher } \\
\text { Education R\&D Survey }\end{array}$ \\
\hline & Total Faculty & WVU Institutional Reports : Census Personnel Work file \\
\hline \multirow[t]{2}{*}{ WVU Recurring Expenditure per Tenured Faculty } & $\begin{array}{l}\text { Recurring Expenditure including Salaries and } \\
\text { Wages }\end{array}$ & WVU Financial Statement 2001-2007 \\
\hline & Tenured Faculty & WVU Institutional Reports : Census Personnel Work file \\
\hline \multirow[t]{2}{*}{$\begin{array}{l}\text { WVU Education Sales and Services per Graduate } \\
\text { Student }\end{array}$} & Sales \& Services of Educational Departments & WVU Financial Statement 2001-2007 \\
\hline & Total Graduate Students & WVU Institutional Report : Higher Education Planning Commission \\
\hline \multicolumn{3}{|l|}{ Industry Variable } \\
\hline Educational Service Representative Units & $\begin{array}{l}\text { Number of Educational and knowledge } \\
\text { Creation Units in the Industry }\end{array}$ & U.S. Bureau of Labor Statistics, Quarterly Census of Employment \& Wages, statsamerica.org \\
\hline \multicolumn{3}{|l|}{ Community Variables } \\
\hline Job to Population Ratio & Number of Jobs per Person & U.S. Census Bureau, Bureau of Economic Analysis \\
\hline Building Permits & Number of Building Permits & U.S. Census Bureau, censtats.census.gov \\
\hline \multirow[t]{2}{*}{$\begin{array}{l}\text { Metropolitan Area and Presence of University } \\
\text { Indicator }\end{array}$} & Metropolitan \& Statistical Area & U.S. Census Bureau, 2010 Census and Census 2000 \\
\hline & Presence of University Indicator & $\begin{array}{l}\text { U.S. Department of Education, Institute of Education Sciences, National Center for Education } \\
\text { Statistics, http://nces.ed.gov/collegenavigator/ }\end{array}$ \\
\hline \multicolumn{3}{|l|}{ Government Variables } \\
\hline \multirow[t]{2}{*}{$\begin{array}{l}\text { Ratio of Federal Government Earnings per Federal } \\
\text { Government Employment }\end{array}$} & Total Federal Earning & U.S. Census Bureau, censtats.census.gov \\
\hline & Total Federal Employment & U.S. Census Bureau, censtats.census.gov \\
\hline \multirow[t]{2}{*}{ Local Government Earnings per Capita } & Total Local Government Earning & U.S. Census Bureau, censtats.census.gov \\
\hline & Total Population & U.S. Census Bureau, censtats.census.gov \\
\hline
\end{tabular}


Table DA2: Data Sources and Description for Total Average Industry Wage Model

\begin{tabular}{|c|c|c|}
\hline Variables Names & Description & Sources \\
\hline \multicolumn{3}{|l|}{ Dependent Variable : } \\
\hline Total Average Industry Wage & $\begin{array}{l}\text { Total Average Wage in the } \\
\text { Industry }\end{array}$ & U.S. Bureau of Labor Statistics, Quarterly Census of Employment \& Wages, statsamerica.org \\
\hline \multicolumn{3}{|l|}{ Independent Variables : } \\
\hline \multicolumn{3}{|l|}{ University Variables } \\
\hline \multirow[t]{2}{*}{$\begin{array}{l}\text { WVU Educational Sales and Services per } \\
\text { Faculty }\end{array}$} & Educational Sales \& Services & WVU Financial Statement 2001-2007 \\
\hline & Total Faculty & WVU Institutional Reports : Census Personnel Work file \\
\hline \multirow[t]{2}{*}{$\begin{array}{l}\text { WVU Recurring Expenditure per Tenured } \\
\text { Faculty }\end{array}$} & $\begin{array}{l}\text { University Recurring } \\
\text { Expenditure }\end{array}$ & WVU Financial Statement 2001-2007 \\
\hline & Tenured Faculty & WVU Institutional Reports : Census Personnel Work file \\
\hline WVU STEM Post Doctoral Students & $\begin{array}{l}\text { Science Engineering Health } \\
\text { Post Doctorate Student }\end{array}$ & $\begin{array}{l}\text { National Science Foundation, National Center for Science and Engineering Statistics, Survey of } \\
\text { Graduate Students and Post doctorates in Science and Engineering }\end{array}$ \\
\hline \multicolumn{3}{|l|}{ Industry Variable } \\
\hline STEM Industry Earnings & $\begin{array}{l}\text { STEM Industry Earnings in } \\
\text { Dollars }\end{array}$ & $\begin{array}{l}\text { National Science Foundation, National Center for Science and Engineering Statistics, Higher } \\
\text { Education R\&D Survey }\end{array}$ \\
\hline \multicolumn{3}{|l|}{ Community Variables } \\
\hline Violent Crimes & Number of Violent Crimes & U.S. Census Bureau, censtats.census.gov \\
\hline \multirow[t]{2}{*}{$\begin{array}{l}\text { Metropolitan Statistical Area and } \\
\text { Presence of University Indicator }\end{array}$} & $\begin{array}{l}\text { Metropolitan \& Statistical } \\
\text { Area }\end{array}$ & U.S. Census Bureau, 2010 Census and Census 2000 \\
\hline & $\begin{array}{l}\text { Presence of University } \\
\text { Indicator }\end{array}$ & \\
\hline \multicolumn{3}{|l|}{ Government Variable } \\
\hline \multirow[t]{2}{*}{$\begin{array}{l}\text { Ratio of Local Government Earnings to } \\
\text { Local Government Employment }\end{array}$} & Local Government Earning & U.S. Census Bureau, censtats.census.gov \\
\hline & $\begin{array}{l}\text { Local Government } \\
\text { Employment }\end{array}$ & U.S. Census Bureau, censtats.census.gov \\
\hline
\end{tabular}


Table DA3: Data Sources and Description for Poverty Rate Model

\begin{tabular}{|c|c|c|}
\hline Variable Names & Description & Sources \\
\hline \multicolumn{3}{|l|}{ Dependent Variable : } \\
\hline Poverty Rate & $\begin{array}{l}\text { Percentage of Population Below the } \\
\text { Poverty Line }\end{array}$ & U.S. Census Bureau, Bureau of Economic Analysis, statsamerica.org \\
\hline \multicolumn{3}{|l|}{ Independent Variables : } \\
\hline \multicolumn{3}{|l|}{ University Variables } \\
\hline \multirow[t]{2}{*}{$\begin{array}{l}\text { WVU Non-STEM R\&D Expenditure per } \\
\text { Post Doctorate Student }\end{array}$} & $\begin{array}{l}\text { WVU Non-STEM Research and } \\
\text { Development Expenditure }\end{array}$ & $\begin{array}{l}\text { National Science Foundation, National Center for Science and Engineering Statistics, Higher } \\
\text { Education R\&D Survey }\end{array}$ \\
\hline & $\begin{array}{l}\text { Total Number of Science Engineering } \\
\text { Health Post Doctorate Students }\end{array}$ & $\begin{array}{l}\text { National Science Foundation, National Center for Science and Engineering Statistics, Survey of } \\
\text { Graduate Students and Post doctorates in Science and Engineering }\end{array}$ \\
\hline $\begin{array}{l}\text { Number of STEM Graduate Students in } \\
\text { WVU }\end{array}$ & $\begin{array}{l}\text { Total number of Science Engineering } \\
\text { Health Graduate Students }\end{array}$ & $\begin{array}{l}\text { National Science Foundation, National Center for Science and Engineering Statistics, Survey of } \\
\text { Graduate Students and Post doctorates in Science and Engineering }\end{array}$ \\
\hline \multicolumn{3}{|l|}{ Industry Variable } \\
\hline STEM Industry Earnings & STEM Industry Earnings in Dollars & $\begin{array}{l}\text { National Science Foundation, National Center for Science and Engineering Statistics, Higher } \\
\text { Education R\&D Survey }\end{array}$ \\
\hline \multicolumn{3}{|l|}{ Community Variables } \\
\hline Metropolitan Area Indicator & Metropolitan \& Statistical Area & U.S. Census Bureau, 2010 Census and Census 2000 \\
\hline \multicolumn{3}{|l|}{ Government Variable } \\
\hline \multirow[t]{2}{*}{ Federal Government Employment per Capita } & Total Federal Government Employment & U.S. Census Bureau, censtats.census.gov \\
\hline & Total Population & U.S. Census Bureau, censtats.census.gov \\
\hline
\end{tabular}


Table DA4: Data Sources and Description for Public School Enrollment per Capita Model

\begin{tabular}{|c|c|c|}
\hline Variable Names & Description & Sources \\
\hline \multicolumn{3}{|l|}{ Dependent Variable : } \\
\hline \multirow[t]{2}{*}{ Public School Enrolment per Capita } & $\begin{array}{l}\text { Number of Students Enrolled in Public } \\
\text { Schools }\end{array}$ & U.S. Census Bureau, censtats.census.gov \\
\hline & Total Population & U.S. Census Bureau, censtats.census.gov \\
\hline \multicolumn{3}{|l|}{ Independent Variables : } \\
\hline \multicolumn{3}{|l|}{ University Variables } \\
\hline \multirow[t]{2}{*}{ WVU Grants per Undergraduate Students } & $\begin{array}{l}\text { Total (Federal, State, Local Government } \\
\text { and Non-Government) Grants }\end{array}$ & WVU Financial Statement 2001-2007 \\
\hline & Total Number of Undergraduate Students & WVU Institutional Report : Higher Education Planning Commission \\
\hline \multirow[t]{2}{*}{$\begin{array}{l}\text { WVU Recurring Expenditure per Post } \\
\text { Doctorate Student }\end{array}$} & $\begin{array}{l}\text { Recurring Expenditure including Salaries } \\
\text { and Wages }\end{array}$ & WVU Financial Statement 2001-2007 \\
\hline & $\begin{array}{l}\text { Total Number of Science Engineering } \\
\text { Health Post Doctorate Students }\end{array}$ & $\begin{array}{l}\text { National Science Foundation, National Center for Science and Engineering Statistics, Survey of } \\
\text { Graduate Students and Post doctorates in Science and Engineering }\end{array}$ \\
\hline \multirow[t]{2}{*}{$\begin{array}{l}\text { WVU Capital Asset Investment per Doctoral } \\
\text { Student }\end{array}$} & Capital Asset Investment in Dollars & WVU Financial Statement 2001-2007 \\
\hline & Number of Earned Doctorate Students & WVU Institutional Report : Higher Education Planning Commission \\
\hline \multicolumn{3}{|l|}{ Industry Variable } \\
\hline \multirow[t]{2}{*}{$\begin{array}{l}\text { Ratio of STEM to Non STEM Jobs in } \\
\text { Industry }\end{array}$} & Number of STEM Jobs in the Industry & $\begin{array}{l}\text { U.S. Bureau of Labor Statistics, Quarterly Census of Employment \& Wages (QCEW) and Purdue } \\
\text { Center for Regional Development, statsamerica.org }\end{array}$ \\
\hline & Number of Non-STEM Jobs in Industry & $\begin{array}{l}\text { U.S. Bureau of Labor Statistics, Quarterly Census of Employment \& Wages (QCEW) and Purdue } \\
\text { Center for Regional Development, statsamerica.org }\end{array}$ \\
\hline \multicolumn{3}{|r|}{ 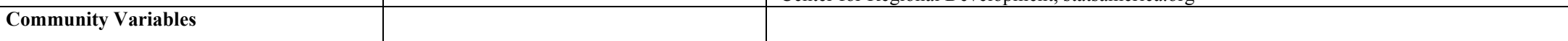 } \\
\hline Violent Crimes & Number of Violent Crimes & U.S. Census Bureau, censtats.census.gov \\
\hline \multicolumn{3}{|l|}{ Government Variable } \\
\hline \multirow[t]{2}{*}{$\begin{array}{l}\text { Federal Government Expenditure per } \\
\text { Federal Employment }\end{array}$} & Total Federal Expenditure & U.S. Census Bureau, censtats.census.gov \\
\hline & Total Federal Employment & U.S. Census Bureau, censtats.census.gov \\
\hline
\end{tabular}




\section{Table DA5: Data Sources and Description for Industrial Earnings per Unit Model}

\begin{tabular}{|c|c|c|}
\hline Variables & Description & Sources \\
\hline \multicolumn{3}{|l|}{ Dependent Variable : } \\
\hline \multirow[t]{2}{*}{ Industrial Earnings per Unit } & Total Industry Earnings & U.S. Census Bureau, censtats.census.gov \\
\hline & Total Industry Units & U.S. Census Bureau, censtats.census.gov \\
\hline \multicolumn{3}{|l|}{ Independent Variables: } \\
\hline \multicolumn{3}{|l|}{ University Variables } \\
\hline \multirow[t]{2}{*}{$\begin{array}{l}\text { WVU Educational Sales and Services per Graduate } \\
\text { Assistant }\end{array}$} & $\begin{array}{l}\text { Sales \& Services of Educational } \\
\text { Departments }\end{array}$ & WVU Financial Statement 2001-2007 \\
\hline & Total Graduate Assistants & WVU Institutional Report : Higher Education Planning Commission \\
\hline \multirow[t]{2}{*}{ WVU Auxiliary Enterprise Fee per Graduate Student } & Auxiliary Enterprise Fee & WVU Financial Statement 2001-2007 \\
\hline & Total Graduate Students & WVU Institutional Report : Higher Education Planning Commission \\
\hline \multirow[t]{2}{*}{ WVU Recurring Expenditure per Graduate Student } & $\begin{array}{l}\text { Recurring Expenditure including } \\
\text { Salaries and Wages }\end{array}$ & WVU Financial Statement 2001-2007 \\
\hline & Total Graduate Students & WVU Institutional Report : Higher Education Planning Commission \\
\hline \multicolumn{3}{|l|}{ Industry Variable } \\
\hline Business Units with less than 10,000 Workers & $\begin{array}{l}\text { Smallest Establishments per Ten } \\
\text { Thousand Workers }\end{array}$ & U.S. Census Bureau, statsamerica.org \\
\hline Educational Services Jobs & $\begin{array}{l}\text { Number of Educational Services Jobs in } \\
\text { the Industry }\end{array}$ & U.S. Bureau of Labor Statistics, Quarterly Census of Employment \& Wages, statsamerica.org \\
\hline Share of High Tech Employment & $\begin{array}{l}\text { Share of High Tech Employment in } \\
\text { Total Employment }\end{array}$ & $\begin{array}{l}\text { Moody's Economy.com, U.S. Census Bureau, Bureau of Labor Statistics, Bureau of Economic } \\
\text { Analysis }\end{array}$ \\
\hline \multirow[t]{2}{*}{ Ratio of STEM to Non-STEM Average Wages } & Average Wages of STEM Industry Units & $\begin{array}{l}\text { U.S. Bureau of Labor Statistics, Quarterly Census of Employment \& Wages (QCEW) and } \\
\text { Purdue Center for Regional Development, statsamerica.org }\end{array}$ \\
\hline & $\begin{array}{l}\text { Average Wages of Non-STEM Industry } \\
\text { Units }\end{array}$ & $\begin{array}{l}\text { U.S. Bureau of Labor Statistics, Quarterly Census of Employment \& Wages (QCEW) and } \\
\text { Purdue Center for Regional Development, statsamerica.org }\end{array}$ \\
\hline \multicolumn{3}{|l|}{ Community Variables } \\
\hline Metropolitan Statistical Area Indicator & Metropolitan \& Statistical Area & U.S. Census Bureau, 2010 Census and Census 2000 \\
\hline \multicolumn{3}{|l|}{ Government Variable } \\
\hline \multirow[t]{2}{*}{$\begin{array}{l}\text { Ratio of Local Government Earnings to Local } \\
\text { Government Employment }\end{array}$} & Total Local Government Earning & U.S. Census Bureau, censtats.census.gov \\
\hline & Total Local Government Employment & U.S. Census Bureau, censtats.census.gov \\
\hline
\end{tabular}


Table DA6: Data Sources and Description for Patents per STEM Industrial Units Model

\begin{tabular}{|c|c|c|}
\hline Variables & Description & Sources \\
\hline \multicolumn{3}{|l|}{ Dependent Variable : } \\
\hline \multirow[t]{2}{*}{ Patents per STEM Industrial Units } & Number of Utility Patents & U.S. Patent and Trademark Office, http://www.uspto.gov/web/offices/ac/ido/oeip/taf/data/ \\
\hline & Number of STEM Industrial units & U.S. Bureau of Labor Statistics, Quarterly Census of Employment \& Wages, statsamerica.org \\
\hline \multicolumn{3}{|l|}{ Independent Variables : } \\
\hline \multicolumn{3}{|l|}{ University Variables } \\
\hline \multirow[t]{2}{*}{$\begin{array}{l}\text { WVU STEM Federal Grant per } \\
\text { Undergraduate Student }\end{array}$} & $\begin{array}{l}\text { Science and Engineering (STEM) } \\
\text { Federal Grant }\end{array}$ & $\begin{array}{l}\text { National Science Foundation/Division of Science Resources Statistics, Survey of Federal Science and } \\
\text { Engineering Support to Universities, Colleges, and Nonprofit Institutions, Fiscal Year } 2000\end{array}$ \\
\hline & Undergraduate Students & WVU Institutional Report : Higher Education Planning Commission \\
\hline \multirow[t]{2}{*}{$\begin{array}{l}\text { WVU STEM Federal Grant per STEM } \\
\text { Graduate Student }\end{array}$} & $\begin{array}{l}\text { Science and Engineering (STEM) } \\
\text { Grant }\end{array}$ & $\begin{array}{l}\text { National Science Foundation/Division of Science Resources Statistics, Survey of Federal Science and } \\
\text { Engineering Support to Universities, Colleges, and Nonprofit Institutions, Fiscal Year } 2000\end{array}$ \\
\hline & $\begin{array}{l}\text { Science Engineering Health Post } \\
\text { (STEM) Doctorate Students }\end{array}$ & $\begin{array}{l}\text { National Science Foundation, National Center for Science and Engineering Statistics, Survey of Graduate } \\
\text { Students and Post doctorates in Science and Engineering }\end{array}$ \\
\hline \multirow[t]{2}{*}{$\begin{array}{l}\text { WVU Non-STEM R\&D Expenditure per } \\
\text { STEM Post-Doctorate Student }\end{array}$} & $\begin{array}{l}\text { Non STEM Research and } \\
\text { Development Expenditure }\end{array}$ & $\begin{array}{l}\text { National Science Foundation, National Center for Science and Engineering Statistics, Higher Education R\&D } \\
\text { Survey }\end{array}$ \\
\hline & $\begin{array}{l}\text { Science Engineering Health } \\
\text { (STEM)Post Doctorate Students }\end{array}$ & $\begin{array}{l}\text { National Science Foundation, National Center for Science and Engineering Statistics, Survey of Graduate } \\
\text { Students and Post doctorates in Science and Engineering }\end{array}$ \\
\hline $\begin{array}{l}\text { WVU Number of STEM Graduate } \\
\text { Students }\end{array}$ & $\begin{array}{l}\text { Science Engineering Health } \\
\text { (STEM) Graduate Students }\end{array}$ & $\begin{array}{l}\text { National Science Foundation, National Center for Science and Engineering Statistics, Survey of Graduate } \\
\text { Students and Post doctorates in Science and Engineering }\end{array}$ \\
\hline WVU Number of Graduate Students & Graduate Students & WVU Institutional Report : Higher Education Planning Commission \\
\hline \multicolumn{3}{|l|}{ Industry Variable } \\
\hline Manufacturing Sector Average Wage & $\begin{array}{l}\text { Average Manufacturing Wages in } \\
\text { Dollars }\end{array}$ & U.S. Bureau of Labor Statistics, Quarterly Census of Employment \& Wages, statsamerica.org \\
\hline Mining Sector Average Wage & Average Mining Wages in Dollars & U.S. Bureau of Labor Statistics, Quarterly Census of Employment \& Wages, statsamerica.org \\
\hline \multicolumn{3}{|l|}{ Community Variables } \\
\hline \multirow[t]{2}{*}{$\begin{array}{l}\text { Metropolitan Area and Presence of } \\
\text { University Indicator }\end{array}$} & Metropolitan \& Statistical Area & U.S. Census Bureau, 2010 Census and Census 2000 \\
\hline & Presence of University Indicator & $\begin{array}{l}\text { U.S. Department of Education, Institute of Education Sciences, National Center for Education Statistics, } \\
\text { http://nces.ed.gov/collegenavigator/ }\end{array}$ \\
\hline \multicolumn{3}{|l|}{ Government Variable } \\
\hline \multirow[t]{2}{*}{$\begin{array}{l}\text { Total Federal Government Expenditure } \\
\text { per Federal Government Earning }\end{array}$} & Total Federal Expenditure & U.S. Census Bureau, censtats.census.gov \\
\hline & Total Federal Earning & U.S. Census Bureau, censtats.census.gov \\
\hline
\end{tabular}




\section{Result Appendix}

Table RA1: Unit Root Test for Income Per capita Model

\begin{tabular}{|c|c|c|c|c|}
\hline Variable & $\begin{array}{c}\mathrm{H}_{0}: \\
\text { Null } \\
\text { Hypothesis }\end{array}$ & $\begin{array}{l}\qquad \mathrm{H}_{1} \text { : } \\
\text { Alternative } \\
\text { Hypothesis }\end{array}$ & t-statistics $^{28}$ & p-value \\
\hline Income per capita in Dollars (D) & $\begin{array}{l}\text { Existence of } \\
\text { Unit Root }\end{array}$ & $\begin{array}{l}\text { Absence of } \\
\text { Unit Root }\end{array}$ & 5.48 & 0.01 \\
\hline $\begin{array}{l}\text { West Virginia University (WVU) STEM } \\
\text { R\&D Expenditure per Faculty in Dollars } \\
\text { (U) }\end{array}$ & $\begin{array}{l}\text { Existence of } \\
\text { Unit Root }\end{array}$ & $\begin{array}{l}\text { Absence of } \\
\text { Unit Root }\end{array}$ & 8.84 & 0.01 \\
\hline $\begin{array}{l}\text { WVU Recurring Expenditure per Tenured } \\
\text { Faculty in Dollars (U) }\end{array}$ & $\begin{array}{l}\text { Existence of } \\
\text { Unit Root }\end{array}$ & $\begin{array}{l}\text { Absence of } \\
\text { Unit Root }\end{array}$ & 3.86 & 0.01 \\
\hline $\begin{array}{l}\text { WVU Education Sales and Services per } \\
\text { Graduate Student in Dollars (U) }\end{array}$ & $\begin{array}{l}\text { Existence of } \\
\text { Unit Root }\end{array}$ & $\begin{array}{l}\text { Absence of } \\
\text { Unit Root }\end{array}$ & 4.57 & 0.01 \\
\hline $\begin{array}{l}\text { Educational Service Representative Units } \\
\text { (I) }\end{array}$ & $\begin{array}{l}\text { Existence of } \\
\text { Unit Root }\end{array}$ & $\begin{array}{l}\text { Absence of } \\
\text { Unit Root }\end{array}$ & 4.53 & 0.01 \\
\hline Job to Population Ratio $(\mathrm{C})$ & $\begin{array}{l}\text { Existence of } \\
\text { Unit Root }\end{array}$ & $\begin{array}{l}\text { Absence of } \\
\text { Unit Root }\end{array}$ & 4.72 & 0.01 \\
\hline Building Permits (C) & $\begin{array}{l}\text { Existence of } \\
\text { Unit Root }\end{array}$ & $\begin{array}{l}\text { Absence of } \\
\text { Unit Root }\end{array}$ & 5.73 & 0.01 \\
\hline $\begin{array}{l}\text { Metropolitan Area and Presence of } \\
\text { University Indicator (C) }\end{array}$ & $\begin{array}{l}\text { Existence of } \\
\text { Unit Root }\end{array}$ & $\begin{array}{l}\text { Absence of } \\
\text { Unit Root }\end{array}$ & - & - \\
\hline $\begin{array}{l}\text { Ratio of Federal Earnings to Federal } \\
\text { Government Employment in Dollars }(\mathrm{G})\end{array}$ & $\begin{array}{l}\text { Existence of } \\
\text { Unit Root }\end{array}$ & $\begin{array}{l}\text { Absence of } \\
\text { Unit Root }\end{array}$ & 6.35 & 0.01 \\
\hline $\begin{array}{l}\text { Local Government Earnings Per Capita in } \\
\text { Dollars }(G)\end{array}$ & $\begin{array}{l}\text { Existence of } \\
\text { Unit Root }\end{array}$ & $\begin{array}{l}\text { Absence of } \\
\text { Unit Root }\end{array}$ & 5.79 & 0.01 \\
\hline
\end{tabular}

Source: Author computed

\footnotetext{
${ }^{28}$ t-statistics reported here is based on Dickey-Fuller t-distribution
} 
Table RA2: Unit Root Test for Total Average Industry Wage Model

\begin{tabular}{|l|c|c|c|c|}
\hline \multicolumn{1}{|c|}{ Variable } & $\begin{array}{c}\mathbf{H}_{\mathbf{0}} \text { : } \\
\text { Null } \\
\text { Hypothesis }\end{array}$ & $\begin{array}{c}\mathbf{H}_{\mathbf{1}} \text { : } \\
\text { Alternative } \\
\text { Hypothesis }\end{array}$ & t-statistics $^{\mathbf{2 9}}$ & p-value \\
\hline Total Average Industry Wage (D) & $\begin{array}{c}\text { Existence of } \\
\text { Unit Root }\end{array}$ & $\begin{array}{c}\text { Absence of } \\
\text { Unit Root }\end{array}$ & 6.18 & 0.01 \\
\hline $\begin{array}{l}\text { WVU Educational Sales and Services } \\
\text { per Faculty in Dollars (U) }\end{array}$ & $\begin{array}{c}\text { Existence of } \\
\text { Unit Root }\end{array}$ & $\begin{array}{c}\text { Absence of } \\
\text { Unit Root }\end{array}$ & 4.66 & 0.01 \\
\hline $\begin{array}{l}\text { WVU Recurring Expenditure per } \\
\text { Tenured Faculty in Dollars (U) }\end{array}$ & $\begin{array}{c}\text { Existence of } \\
\text { Unit Root }\end{array}$ & $\begin{array}{c}\text { Absence of } \\
\text { Unit Root }\end{array}$ & 3.86 & 0.02 \\
\hline $\begin{array}{l}\text { WVU STEM Post-Doctoral Students } \\
\text { (U) }\end{array}$ & $\begin{array}{c}\text { Existence of } \\
\text { Unit Root }\end{array}$ & $\begin{array}{c}\text { Absence of } \\
\text { Unit Root }\end{array}$ & 3.66 & 0.04 \\
\hline $\begin{array}{l}\text { STEM Industrial Earnings in Dollars } \\
\text { (I) }\end{array}$ & $\begin{array}{c}\text { Existence of } \\
\text { Unit Root }\end{array}$ & $\begin{array}{c}\text { Absence of } \\
\text { Unit Root }\end{array}$ & 3.54 & 0.04 \\
\hline $\begin{array}{l}\text { Violent Crimes (C) } \\
\text { Unistence of Root }\end{array}$ & $\begin{array}{c}\text { Absence of } \\
\text { Unit Root }\end{array}$ & 4.63 & 0.01 \\
\hline $\begin{array}{l}\text { Metropolitan Statistical Area and } \\
\text { Presence of University Indicator (C) }\end{array}$ & $\begin{array}{c}\text { Existence of } \\
\text { Unit Root }\end{array}$ & $\begin{array}{c}\text { Absence of } \\
\text { Unit Root }\end{array}$ & - & - \\
\hline $\begin{array}{l}\text { Ratio of Local Government Earnings } \\
\text { to Local Government Employment in } \\
\text { Dollars(G) }\end{array}$ & $\begin{array}{c}\text { Existence of } \\
\text { Unit Root }\end{array}$ & $\begin{array}{c}\text { Absence of } \\
\text { Unit Root }\end{array}$ & 4.97 & 0.01 \\
\hline
\end{tabular}

Source: Author computed

${ }^{29}$ t-statistics reported here is based on Dickey-Fuller t-distribution 
Table RA3: Unit Root Test for Statistics for Poverty Rate Model

\begin{tabular}{|c|c|c|c|c|}
\hline Variable & $\begin{array}{c}\mathrm{H}_{0}: \\
\text { Null } \\
\text { Hypothesis }\end{array}$ & $\begin{array}{l}\qquad \mathrm{H}_{1} \text { : } \\
\text { Alternative } \\
\text { Hypothesis }\end{array}$ & statistics $^{\text {to }}$ & p-value \\
\hline Poverty Rate (D) & $\begin{array}{l}\text { Existence of } \\
\text { Unit Root }\end{array}$ & $\begin{array}{c}\text { Absence of } \\
\text { Unit Root }\end{array}$ & 4.74 & 0.01 \\
\hline $\begin{array}{l}\text { WVU Non-STEM R\&D Expenditure } \\
\text { per Post Doctorate Student in Dollars } \\
\text { (U) }\end{array}$ & $\begin{array}{l}\text { Existence of } \\
\text { Unit Root }\end{array}$ & $\begin{array}{l}\text { Absence of } \\
\text { Unit Root }\end{array}$ & 6.31 & 0.01 \\
\hline $\begin{array}{l}\text { Number of STEM Graduate Students } \\
\text { in WVU }(U)\end{array}$ & $\begin{array}{l}\text { Existence of } \\
\text { Unit Root }\end{array}$ & $\begin{array}{l}\text { Absence of } \\
\text { Unit Root }\end{array}$ & 5.49 & 0.01 \\
\hline $\begin{array}{l}\text { STEM Industrial Earnings in Dollars } \\
\text { (I) }\end{array}$ & $\begin{array}{l}\text { Existence of } \\
\text { Unit Root }\end{array}$ & $\begin{array}{l}\text { Absence of } \\
\text { Unit Root }\end{array}$ & 4.63 & 0.01 \\
\hline $\begin{array}{l}\text { Metropolitan Statistical Area Indicator } \\
\text { (C) }\end{array}$ & $\begin{array}{l}\text { Existence of } \\
\text { Unit Root }\end{array}$ & $\begin{array}{l}\text { Absence of } \\
\text { Unit Root }\end{array}$ & - & - \\
\hline $\begin{array}{l}\text { Federal Government Employment per } \\
\text { capita }(\mathrm{G})\end{array}$ & $\begin{array}{l}\text { Existence of } \\
\text { Unit Root }\end{array}$ & $\begin{array}{l}\text { Absence of } \\
\text { Unit Root }\end{array}$ & 4.93 & 0.01 \\
\hline
\end{tabular}

Source: Author computed

${ }^{30} \mathrm{t}$-statistics reported here is based on Dickey-Fuller t-distribution 
Table RA4: Unit Root Test for Public School Enrollment Per Capita Model

\begin{tabular}{|l|c|c|c|l|}
\hline \multicolumn{1}{|c|}{ Variable } & $\begin{array}{c}\mathbf{H}_{\mathbf{0}} \text { : } \\
\text { Null } \\
\text { Hypothesis }\end{array}$ & $\begin{array}{c}\mathbf{H}_{\mathbf{1}} \text { : } \\
\text { Alternative } \\
\text { Hypothesis }\end{array}$ & $\begin{array}{c}\mathbf{t} \text { - } \\
\text { statistics }^{\mathbf{3 1}}\end{array}$ & p-value \\
\hline $\begin{array}{l}\text { Public School Enrollment per capita } \\
\text { (D) }\end{array}$ & $\begin{array}{c}\text { Existence of } \\
\text { Unit Root }\end{array}$ & $\begin{array}{c}\text { Absence of } \\
\text { Unit Root }\end{array}$ & 5.07 & 0.01 \\
\hline $\begin{array}{l}\text { WVU Grants per Undergraduate } \\
\text { Student (U) }\end{array}$ & $\begin{array}{c}\text { Existence of } \\
\text { Unit Root }\end{array}$ & $\begin{array}{c}\text { Absence of } \\
\text { Unit Root }\end{array}$ & 5.97 & 0.01 \\
\hline $\begin{array}{l}\text { WVU Recurring Expenditure per Post } \\
\text { Doctorate Student (U) }\end{array}$ & $\begin{array}{c}\text { Existence of } \\
\text { Unit Root }\end{array}$ & $\begin{array}{c}\text { Absence of } \\
\text { Unit Root }\end{array}$ & 4.33 & 0.01 \\
\hline $\begin{array}{l}\text { WVU Capital Asset Investment per } \\
\text { Doctoral Students (U) }\end{array}$ & $\begin{array}{c}\text { Existence of } \\
\text { Unit Root }\end{array}$ & $\begin{array}{c}\text { Absence of } \\
\text { Unit Root }\end{array}$ & 6.14 & 0.01 \\
\hline $\begin{array}{l}\text { Ratio of STEM to NON STEM Jobs in } \\
\text { Industries (I) }\end{array}$ & $\begin{array}{c}\text { Existence of } \\
\text { Unit Root }\end{array}$ & $\begin{array}{c}\text { Absence of } \\
\text { Unit Root }\end{array}$ & 6.96 & 0.01 \\
\hline Violent Crimes (C) & $\begin{array}{c}\text { Existence of } \\
\text { Unit Root }\end{array}$ & $\begin{array}{c}\text { Absence of } \\
\text { Unit Root }\end{array}$ & 4.63 & 0.01 \\
\hline $\begin{array}{l}\text { Federal Government Expenditure per } \\
\text { Federal Employment (G) }\end{array}$ & $\begin{array}{c}\text { Existence of } \\
\text { Unit Root }\end{array}$ & $\begin{array}{c}\text { Absence of } \\
\text { Unit Root }\end{array}$ & 5.04 & 0.01 \\
\hline
\end{tabular}

Source: Author computed

${ }^{31} \mathrm{t}$-statistics reported here is based on Dickey-Fuller t-distribution 
Table RA5: Unit Root Test for Industrial Earnings Per Industrial Unit Model

\begin{tabular}{|l|c|c|c|c|}
\hline \multicolumn{1}{|c|}{ Variable } & \multicolumn{1}{|c|}{$\begin{array}{c}\mathbf{H}_{\mathbf{0}} \text { : } \\
\text { Null } \\
\text { Hypothesis }\end{array}$} & $\begin{array}{c}\mathbf{H}_{\mathbf{1}} \text { : } \\
\text { Alternative } \\
\text { Hypothesis }\end{array}$ & $\begin{array}{c}\mathbf{t} \text { - } \\
\text { statistics }^{32}\end{array}$ & p-value \\
\hline Industrial Earnings Per Industrial Unit (D) & $\begin{array}{c}\text { Existence of } \\
\text { Unit Root }\end{array}$ & $\begin{array}{c}\text { Absence of } \\
\text { Unit Root }\end{array}$ & 5.88 & 0.01 \\
\hline $\begin{array}{l}\text { WVU Educational Sales Services per } \\
\text { Graduate Student (U) }\end{array}$ & $\begin{array}{c}\text { Existence of } \\
\text { Unit Root }\end{array}$ & $\begin{array}{c}\text { Absence of } \\
\text { Unit Root }\end{array}$ & 4.83 & 0.01 \\
\hline $\begin{array}{l}\text { WVU Auxiliary Fee per Graduate } \\
\text { Student(U) }\end{array}$ & $\begin{array}{c}\text { Existence of } \\
\text { Unit Root }\end{array}$ & $\begin{array}{c}\text { Absence of } \\
\text { Unit Root }\end{array}$ & 3.86 & 0.01 \\
\hline $\begin{array}{l}\text { WVU Recurring Expenditure per Graduate } \\
\text { Student (U) }\end{array}$ & $\begin{array}{c}\text { Existence of } \\
\text { Unit Root }\end{array}$ & $\begin{array}{c}\text { Absence of } \\
\text { Unit Root }\end{array}$ & 4.92 & 0.01 \\
\hline $\begin{array}{l}\text { Industrial Units with less than 10,000 } \\
\text { workers (I) }\end{array}$ & $\begin{array}{c}\text { Existence of } \\
\text { Unit Root }\end{array}$ & $\begin{array}{c}\text { Absence of } \\
\text { Unit Root }\end{array}$ & 5.24 & 0.01 \\
\hline Educational Service Jobs (I) & $\begin{array}{c}\text { Existence of } \\
\text { Unit Root }\end{array}$ & $\begin{array}{c}\text { Absence of } \\
\text { Unit Root }\end{array}$ & 5.20 & 0.01 \\
\hline $\begin{array}{l}\text { Ratio of STEM to Non-STEM Average } \\
\text { Wages (I) }\end{array}$ & $\begin{array}{c}\text { Existence of } \\
\text { Unit Root }\end{array}$ & $\begin{array}{c}\text { Absence of } \\
\text { Unit Root }\end{array}$ & 6.64 & 0.01 \\
\hline Share of Hi-Tech Employment (I) & $\begin{array}{c}\text { Existence of } \\
\text { Unit Root }\end{array}$ & $\begin{array}{c}\text { Absence of } \\
\text { Unit Root }\end{array}$ & 5.33 & 0.01 \\
\hline Metropolitan Statistical Area Indicator (C) & $\begin{array}{c}\text { Existence of } \\
\text { Unit Root }\end{array}$ & $\begin{array}{c}\text { Absence of } \\
\text { Unit Root }\end{array}$ & - & 0.01 \\
\hline $\begin{array}{l}\text { Ratio of Local Government Earning to } \\
\text { Local Government Employment (G) }\end{array}$ & $\begin{array}{c}\text { Existence of } \\
\text { Unit Root }\end{array}$ & $\begin{array}{c}\text { Absence of } \\
\text { Unit Root }\end{array}$ & 4.98 & 0.01 \\
\hline
\end{tabular}

Source: Author computed

${ }^{32} \mathrm{t}$-statistics reported here is based on Dickey-Fuller t-distribution 
Table RA6: Unit Root Test for Patents per STEM Industrial Unit Model

\begin{tabular}{|c|c|c|c|c|}
\hline Variable & $\begin{array}{c}\mathrm{H}_{0}: \\
\text { Null } \\
\text { Hypothesis }\end{array}$ & $\begin{array}{l}\qquad \mathrm{H}_{1} \text { : } \\
\text { Alternative } \\
\text { Hypothesis }\end{array}$ & t-statistics & p-value \\
\hline Patents per STEM Industrial Unit (D) & $\begin{array}{l}\text { Existence of } \\
\text { Unit Root }\end{array}$ & $\begin{array}{l}\text { Absence of } \\
\text { Unit Root }\end{array}$ & 5.56 & 0.01 \\
\hline $\begin{array}{l}\text { WVU Ratio of STEM Grants per } \\
\text { Undergraduate Student (U) }\end{array}$ & $\begin{array}{l}\text { Existence of } \\
\text { Unit Root }\end{array}$ & $\begin{array}{l}\text { Absence of } \\
\text { Unit Root }\end{array}$ & 9.64 & 0.01 \\
\hline $\begin{array}{l}\text { WVU Number of STEM graduate } \\
\text { students (U) }\end{array}$ & $\begin{array}{l}\text { Existence of } \\
\text { Unit Root }\end{array}$ & $\begin{array}{l}\text { Absence of } \\
\text { Unit Root }\end{array}$ & 5.50 & 0.01 \\
\hline $\begin{array}{l}\text { Ratio of Non-STEM R\&D Expenditure } \\
\text { to Number of STEM Post-Doctorate } \\
\text { Student (U) }\end{array}$ & $\begin{array}{l}\text { Existence of } \\
\text { Unit Root }\end{array}$ & $\begin{array}{l}\text { Absence of } \\
\text { Unit Root }\end{array}$ & 6.58 & 0.01 \\
\hline $\begin{array}{l}\text { Ratio of STEM Federal Grant to } \\
\text { Number of STEM Post-Doctorate } \\
\text { Student (U) }\end{array}$ & $\begin{array}{l}\text { Existence of } \\
\text { Unit Root }\end{array}$ & $\begin{array}{l}\text { Absence of } \\
\text { Unit Root }\end{array}$ & 4.16 & 0.01 \\
\hline Number of Graduate Students (U) & $\begin{array}{c}\text { Existence of } \\
\text { Unit Root }\end{array}$ & $\begin{array}{l}\text { Absence of } \\
\text { Unit Root }\end{array}$ & 5.14 & 0.01 \\
\hline $\begin{array}{l}\text { Manufacturing Sector Average Wage } \\
\text { (I) }\end{array}$ & $\begin{array}{l}\text { Existence of } \\
\text { Unit Root }\end{array}$ & $\begin{array}{l}\text { Absence of } \\
\text { Unit Root }\end{array}$ & 5.18 & 0.01 \\
\hline Mining Sector Average Wage (I) & $\begin{array}{l}\text { Existence of } \\
\text { Unit Root }\end{array}$ & $\begin{array}{l}\text { Absence of } \\
\text { Unit Root }\end{array}$ & 4.97 & 0.01 \\
\hline $\begin{array}{l}\text { Metropolitan Statistical Area and } \\
\text { Presence of University Indicator (C) }\end{array}$ & $\begin{array}{c}\text { Existence of } \\
\text { Unit Root }\end{array}$ & $\begin{array}{l}\text { Absence of } \\
\text { Unit Root }\end{array}$ & - & 0.01 \\
\hline $\begin{array}{l}\text { Ratio of Federal Government } \\
\text { Expenditure to Federal Employment } \\
\text { (G) }\end{array}$ & $\begin{array}{l}\text { Existence of } \\
\text { Unit Root }\end{array}$ & $\begin{array}{l}\text { Absence of } \\
\text { Unit Root }\end{array}$ & 4.74 & 0.01 \\
\hline
\end{tabular}

Source: Author computed 
Table RA7: Testing for Normality of Residuals from LSDV Regressions

Dependent Variable: Logarithm of Income per Capita

\begin{tabular}{|c|c|c|c|c|c|}
\hline Test & Equation & $\begin{array}{c}\mathbf{H}_{0}: \\
\text { Null } \\
\text { Hypothesis }\end{array}$ & $\begin{array}{l}\mathrm{H}_{1} \text { : } \\
\text { Alternative } \\
\text { Hypothesis }\end{array}$ & $\begin{array}{l}\text { Chi-Square/ } \\
\text { W - } \\
\text { statistics }^{33}\end{array}$ & p-value \\
\hline \multirow[t]{3}{*}{ Jarque-Bera } & Modell & $\begin{array}{l}\text { Residuals are } \\
\text { normally distributed }\end{array}$ & $\begin{array}{l}\text { Residuals are not } \\
\text { normally distributed }\end{array}$ & 2.70 & 0.26 \\
\hline & Model2 & $\begin{array}{l}\text { Residuals are } \\
\text { normally distributed }\end{array}$ & $\begin{array}{l}\text { Residuals are not } \\
\text { normally distributed }\end{array}$ & 2.26 & 0.33 \\
\hline & Model3 & $\begin{array}{l}\text { Residuals are } \\
\text { normally distributed }\end{array}$ & $\begin{array}{l}\text { Residuals are not } \\
\text { normally distributed }\end{array}$ & 3.64 & 0.16 \\
\hline \multirow[t]{3}{*}{ Shapiro-Wilk } & Modell & $\begin{array}{l}\text { Residuals are } \\
\text { normally distributed }\end{array}$ & $\begin{array}{l}\text { Residuals are not } \\
\text { normally distributed }\end{array}$ & 0.97 & 0.18 \\
\hline & Model2 & $\begin{array}{l}\text { Residuals are } \\
\text { normally distributed }\end{array}$ & $\begin{array}{l}\text { Residuals are not } \\
\text { normally distributed }\end{array}$ & 0.96 & 0.14 \\
\hline & Model3 & $\begin{array}{l}\text { Residuals are } \\
\text { normally distributed }\end{array}$ & $\begin{array}{l}\text { Residuals are not } \\
\text { normally distributed }\end{array}$ & 0.97 & 0.18 \\
\hline
\end{tabular}

Source: Author computed

${ }^{33}$ Chi-Square Statistics for Jarque-Bera Test and W-statistics for Shapiro-Wilk Test 
Table RA8: Testing for Normality of Residuals from LSDV Regressions

Dependent Variable: Logarithm of Total Average Wage

\begin{tabular}{|c|c|c|c|c|c|}
\hline Test & Equation & $\begin{array}{c}\mathrm{H}_{0}: \\
\text { Null } \\
\text { Hypothesis }\end{array}$ & $\begin{array}{c}\mathrm{H}_{1} \text { : } \\
\text { Alternative } \\
\text { Hypothesis }\end{array}$ & $\begin{array}{l}\text { Chi-Square/ } \\
\text { W - } \\
\text { statistics }^{34}\end{array}$ & p-value \\
\hline \multirow[t]{3}{*}{ Jarque-Bera } & Modell & $\begin{array}{l}\text { Residuals are } \\
\text { normally distributed }\end{array}$ & $\begin{array}{l}\text { Residuals are not } \\
\text { normally distributed }\end{array}$ & 3.02 & 0.22 \\
\hline & Model2 & $\begin{array}{l}\text { Residuals are } \\
\text { normally distributed }\end{array}$ & $\begin{array}{l}\text { Residuals are not } \\
\text { normally distributed }\end{array}$ & 0.16 & 0.94 \\
\hline & Model3 & $\begin{array}{l}\text { Residuals are } \\
\text { normally distributed }\end{array}$ & $\begin{array}{l}\text { Residuals are not } \\
\text { normally distributed }\end{array}$ & 4.56 & 0.11 \\
\hline \multirow[t]{3}{*}{ Shapiro-Wilk } & Model1 & $\begin{array}{l}\text { Residuals are } \\
\text { normally distributed }\end{array}$ & $\begin{array}{l}\text { Residuals are not } \\
\text { normally distributed }\end{array}$ & 0.98 & 0.11 \\
\hline & Model2 & $\begin{array}{l}\text { Residuals are } \\
\text { normally distributed }\end{array}$ & $\begin{array}{l}\text { Residuals are not } \\
\text { normally distributed }\end{array}$ & 0.95 & 0.12 \\
\hline & Model3 & $\begin{array}{l}\text { Residuals are } \\
\text { normally distributed }\end{array}$ & $\begin{array}{l}\text { Residuals are not } \\
\text { normally distributed }\end{array}$ & 0.95 & 0.12 \\
\hline
\end{tabular}

Source: Author computed

${ }^{34}$ Chi-Square Statistics for Jarque-Bera Test and W-statistics for Shapiro-Wilk Test 
Table RA9: Testing for Normality of Residuals from LSDV Regressions

Dependent Variable: Logarithm of Poverty Rate

\begin{tabular}{|c|c|c|c|c|c|}
\hline Test & Equation & $\begin{array}{c}\mathbf{H}_{0}: \\
\text { Null } \\
\text { Hypothesis }\end{array}$ & $\begin{array}{c}\mathrm{H}_{1} \text { : } \\
\text { Alternative } \\
\text { Hypothesis }\end{array}$ & $\begin{array}{l}\text { Chi-Square/ } \\
\text { W - } \\
\text { statistics }^{35}\end{array}$ & p-value \\
\hline \multirow[t]{2}{*}{ Jarque-Bera } & Modell & $\begin{array}{l}\text { Residuals are } \\
\text { normally distributed }\end{array}$ & $\begin{array}{l}\text { Residuals are not } \\
\text { normally distributed }\end{array}$ & 0.07 & 0.96 \\
\hline & Model2 & $\begin{array}{l}\text { Residuals are } \\
\text { normally distributed }\end{array}$ & $\begin{array}{l}\text { Residuals are not } \\
\text { normally distributed }\end{array}$ & 0.09 & 0.96 \\
\hline \multirow[t]{2}{*}{ Shapiro-Wilk } & Modell & $\begin{array}{l}\text { Residuals are } \\
\text { normally distributed }\end{array}$ & $\begin{array}{l}\text { Residuals are not } \\
\text { normally distributed }\end{array}$ & 0.99 & 0.48 \\
\hline & Model2 & $\begin{array}{l}\text { Residuals are } \\
\text { normally distributed }\end{array}$ & $\begin{array}{l}\text { Residuals are not } \\
\text { normally distributed }\end{array}$ & 0.99 & 0.48 \\
\hline
\end{tabular}

Source: Author computed

${ }^{35}$ Chi-Square Statistics for Jarque-Bera Test and W-statistics for Shapiro-Wilk Test 
Table RA10: Testing for Normality of Residuals from LSDV Regressions

Dependent Variable: Logarithm of Public School Enrollment per Capita

\begin{tabular}{|c|c|c|c|c|c|}
\hline Test & Equation & $\begin{array}{c}\mathbf{H}_{0}: \\
\text { Null } \\
\text { Hypothesis }\end{array}$ & $\begin{array}{c}\mathrm{H}_{1}: \\
\text { Alternative } \\
\text { Hypothesis }\end{array}$ & $\begin{array}{l}\text { Chi-Square/ } \\
\text { W - } \\
\text { statistics }^{36}\end{array}$ & p-value \\
\hline \multirow[t]{3}{*}{ Jarque-Bera } & Model1 & $\begin{array}{l}\text { Residuals are } \\
\text { normally } \\
\text { distributed }\end{array}$ & $\begin{array}{l}\text { Residuals are not } \\
\text { normally distributed }\end{array}$ & 4.72 & 0.09 \\
\hline & Model2 & $\begin{array}{l}\text { Residuals are } \\
\text { normally } \\
\text { distributed }\end{array}$ & $\begin{array}{l}\text { Residuals are not } \\
\text { normally distributed }\end{array}$ & 2.30 & 0.32 \\
\hline & Model3 & $\begin{array}{l}\text { Residuals are } \\
\text { normally } \\
\text { distributed }\end{array}$ & $\begin{array}{l}\text { Residuals are not } \\
\text { normally distributed }\end{array}$ & 2.27 & 0.19 \\
\hline \multirow[t]{3}{*}{ Shapiro-Wilk } & Model1 & $\begin{array}{l}\text { Residuals are } \\
\text { normally } \\
\text { distributed }\end{array}$ & $\begin{array}{l}\text { Residuals are not } \\
\text { normally distributed }\end{array}$ & 0.98 & 0.11 \\
\hline & Model2 & $\begin{array}{l}\text { Residuals are } \\
\text { normally } \\
\text { distributed }\end{array}$ & $\begin{array}{l}\text { Residuals are not } \\
\text { normally distributed }\end{array}$ & 0.96 & 0.14 \\
\hline & Model3 & $\begin{array}{l}\text { Residuals are } \\
\text { normally } \\
\text { distributed }\end{array}$ & $\begin{array}{l}\text { Residuals are not } \\
\text { normally distributed }\end{array}$ & 0.96 & 0.14 \\
\hline
\end{tabular}

Source: Author computed

${ }^{36}$ Chi-Square Statistics for Jarque-Bera Test and W-statistics for Shapiro-Wilk Test 
Table RA11: Testing for Normality of Residuals from LSDV Regressions

Dependent Variable: Logarithm of Industrial Earning per Industrial Unit

\begin{tabular}{|c|c|c|c|c|c|}
\hline Test & Equation & $\begin{array}{c}\mathbf{H}_{0}: \\
\text { Null } \\
\text { Hypothesis }\end{array}$ & $\begin{array}{c}\mathrm{H}_{1} \text { : } \\
\text { Alternative } \\
\text { Hypothesis }\end{array}$ & $\begin{array}{l}\text { Chi-Square/ } \\
\text { W -statistics }{ }^{37}\end{array}$ & p-value \\
\hline \multirow[t]{3}{*}{ Jarque-Bera } & Model1 & $\begin{array}{l}\text { Residuals are } \\
\text { normally } \\
\text { distributed }\end{array}$ & $\begin{array}{l}\text { Residuals are not } \\
\text { normally distributed }\end{array}$ & 3.94 & 0.14 \\
\hline & Model2 & $\begin{array}{l}\text { Residuals are } \\
\text { normally } \\
\text { distributed }\end{array}$ & $\begin{array}{l}\text { Residuals are not } \\
\text { normally distributed }\end{array}$ & 3.44 & 0.18 \\
\hline & Model3 & $\begin{array}{l}\text { Residuals are } \\
\text { normally } \\
\text { distributed }\end{array}$ & $\begin{array}{l}\text { Residuals are not } \\
\text { normally distributed }\end{array}$ & 4.68 & 0.10 \\
\hline \multirow[t]{3}{*}{ Shapiro-Wilk } & Model1 & $\begin{array}{l}\text { Residuals are } \\
\text { normally } \\
\text { distributed }\end{array}$ & $\begin{array}{l}\text { Residuals are not } \\
\text { normally distributed }\end{array}$ & 0.99 & 0.48 \\
\hline & Model2 & $\begin{array}{l}\text { Residuals are } \\
\text { normally } \\
\text { distributed }\end{array}$ & $\begin{array}{l}\text { Residuals are not } \\
\text { normally distributed }\end{array}$ & 0.99 & 0.48 \\
\hline & Model3 & $\begin{array}{l}\text { Residuals are } \\
\text { normally } \\
\text { distributed }\end{array}$ & $\begin{array}{l}\text { Residuals are not } \\
\text { normally distributed }\end{array}$ & 0.99 & 0.48 \\
\hline
\end{tabular}

Source: Author computed

${ }^{37}$ Chi-Square Statistics for Jarque-Bera Test and W-statistics for Shapiro-Wilk Test 
Table RA12: Testing for Normality of Residuals from LSDV Regressions

Dependent Variable: Patents per Industrial Unit

\begin{tabular}{|c|c|c|c|c|c|}
\hline Test & Equation & $\begin{array}{c}\mathbf{H}_{0}: \\
\text { Null } \\
\text { Hypothesis }\end{array}$ & $\begin{array}{c}\mathrm{H}_{1} \text { : } \\
\text { Alternative } \\
\text { Hypothesis }\end{array}$ & $\begin{array}{l}\text { Chi-Square/ } \\
\text { W-statistics }\end{array}$ & p-value \\
\hline \multirow[t]{5}{*}{ Jarque-Bera } & Model1 & $\begin{array}{l}\text { Residuals are } \\
\text { normally } \\
\text { distributed }\end{array}$ & $\begin{array}{l}\text { Residuals are not } \\
\text { normally distributed }\end{array}$ & 3.31 & 0.19 \\
\hline & Model2 & $\begin{array}{l}\text { Residuals are } \\
\text { normally } \\
\text { distributed }\end{array}$ & $\begin{array}{l}\text { Residuals are not } \\
\text { normally distributed }\end{array}$ & 4.69 & 0.10 \\
\hline & Model3 & $\begin{array}{l}\text { Residuals are } \\
\text { normally } \\
\text { distributed }\end{array}$ & $\begin{array}{l}\text { Residuals are not } \\
\text { normally distributed }\end{array}$ & 4.55 & 0.10 \\
\hline & Model 4 & $\begin{array}{l}\text { Residuals are } \\
\text { normally } \\
\text { distributed }\end{array}$ & $\begin{array}{l}\text { Residuals are not } \\
\text { normally distributed }\end{array}$ & 4.10 & 0.13 \\
\hline & Model 5 & $\begin{array}{l}\text { Residuals are } \\
\text { normally } \\
\text { distributed }\end{array}$ & $\begin{array}{l}\text { Residuals are not } \\
\text { normally distributed }\end{array}$ & 3.68 & 0.16 \\
\hline \multirow[t]{5}{*}{ Shapiro-Wilk } & Model1 & $\begin{array}{l}\text { Residuals are } \\
\text { normally } \\
\text { distributed }\end{array}$ & $\begin{array}{l}\text { Residuals are not } \\
\text { normally distributed }\end{array}$ & 0.98 & 0.11 \\
\hline & Model2 & $\begin{array}{l}\text { Residuals are } \\
\text { normally } \\
\text { distributed }\end{array}$ & $\begin{array}{l}\text { Residuals are not } \\
\text { normally distributed }\end{array}$ & 0.99 & 0.48 \\
\hline & Model3 & $\begin{array}{l}\text { Residuals are } \\
\text { normally } \\
\text { distributed }\end{array}$ & $\begin{array}{l}\text { Residuals are not } \\
\text { normally distributed }\end{array}$ & 0.98 & 0.11 \\
\hline & Model 4 & $\begin{array}{l}\text { Residuals are } \\
\text { normally } \\
\text { distributed }\end{array}$ & $\begin{array}{l}\text { Residuals are not } \\
\text { normally distributed }\end{array}$ & 0.99 & 0.48 \\
\hline & Model 5 & $\begin{array}{l}\text { Residuals are } \\
\text { normally } \\
\text { distributed }\end{array}$ & $\begin{array}{l}\text { Residuals are not } \\
\text { normally distributed }\end{array}$ & 0.98 & 0.11 \\
\hline
\end{tabular}

Source: Author computed

${ }^{38}$ Chi-Square Statistics for Jarque-Bera Test and W-statistics for Shapiro-Wilk Test 
Table RA13: Testing for Time-Fixed Effects LSDV Regressions (F- test for individual effects) Dependent Variable: Logarithm of Income per capita

\begin{tabular}{|l|l|l|c|c|}
\hline Equation & \multicolumn{1}{|c|}{$\begin{array}{c}\mathbf{H}_{\mathbf{0}}: \\
\text { Null } \\
\text { Hypothesis }\end{array}$} & $\begin{array}{c}\mathbf{H}_{\mathbf{1}} \text { : } \\
\text { Alternative } \\
\text { Hypothesis }\end{array}$ & F-statistics & p-value \\
\hline Model1 & No Time Fixed Effects & $\begin{array}{l}\text { Presence of Time } \\
\text { Fixed Effects }\end{array}$ & 19.63 & 0.01 \\
\hline Model2 & No Time Fixed Effects & $\begin{array}{l}\text { Presence of Time } \\
\text { Fixed Effects }\end{array}$ & 14.05 & 0.01 \\
\hline Model3 & No Time Fixed Effects & $\begin{array}{l}\text { Presence of Time } \\
\text { Fixed Effects }\end{array}$ & 14.77 & 0.01 \\
\hline
\end{tabular}

Source: Author computed 
Table RA14: Testing for Time-Fixed Effects LSDV Regressions (F- test for individual effects)

Dependent Variable: Logarithm of Total Average Industry Wage Model

\begin{tabular}{|l|l|l|c|c|}
\hline Equation & \multicolumn{1}{|c|}{$\begin{array}{c}\mathbf{H}_{\mathbf{0}}: \\
\text { Null } \\
\text { Hypothesis }\end{array}$} & $\begin{array}{c}\mathbf{H}_{\mathbf{1}} \text { : } \\
\text { Alternative } \\
\text { Hypothesis }\end{array}$ & F-statistics & p-value \\
\hline Model1 & No Time Fixed Effects & $\begin{array}{l}\text { Presence of Time } \\
\text { Fixed Effects }\end{array}$ & 14.39 & 0.01 \\
\hline Model2 & No Time Fixed Effects & $\begin{array}{l}\text { Presence of Time } \\
\text { Fixed Effects }\end{array}$ & 18.60 & 0.01 \\
\hline Model3 & No Time Fixed Effects & $\begin{array}{l}\text { Presence of Time } \\
\text { Fixed Effects }\end{array}$ & 15.49 & 0.01 \\
\hline
\end{tabular}

Source: Author computed 
Table RA15: Testing for Time-Fixed Effects LSDV Regressions (F- test for individual effects) Dependent Variable: Logarithm of Poverty Rate

\begin{tabular}{|l|l|l|c|c|}
\hline Equation & $\begin{array}{c}\mathbf{H}_{\mathbf{0}}: \\
\text { Null } \\
\text { Hypothesis }\end{array}$ & $\begin{array}{c}\mathbf{H}_{\mathbf{1}}: \\
\text { Alternative } \\
\text { Hypothesis }\end{array}$ & F-statistics & p-value \\
\hline Model1 & No Time Fixed Effects & $\begin{array}{l}\text { Presence of Time } \\
\text { Fixed Effects }\end{array}$ & 291.12 & 0.01 \\
\hline Model2 & No Time Fixed Effects & $\begin{array}{l}\text { Presence of Time } \\
\text { Fixed Effects }\end{array}$ & 316.24 & 0.01 \\
\hline
\end{tabular}

Source: Author computed 
Table RA16: Testing for Time-Fixed Effects LSDV Regressions (F- test for individual effects)

Dependent Variable: Logarithm of Public School Enrollment per Capita

\begin{tabular}{|l|l|l|c|c|}
\hline Equation & \multicolumn{1}{|c|}{$\begin{array}{c}\mathbf{H}_{\mathbf{0}}: \\
\text { Null } \\
\text { Hypothesis }\end{array}$} & $\begin{array}{c}\mathbf{H}_{\mathbf{1}} \text { : } \\
\text { Alternative } \\
\text { Hypothesis }\end{array}$ & F-statistics & p-value \\
\hline Model1 & No Time Fixed Effects & $\begin{array}{l}\text { Presence of Time } \\
\text { Fixed Effects }\end{array}$ & 232.79 & 0.01 \\
\hline Model2 & No Time Fixed Effects & $\begin{array}{l}\text { Presence of Time } \\
\text { Fixed Effects }\end{array}$ & 137.36 & 0.01 \\
\hline Model3 & No Time Fixed Effects & $\begin{array}{l}\text { Presence of Time } \\
\text { Fixed Effects }\end{array}$ & 267.99 & 0.01 \\
\hline
\end{tabular}

Source: Author computed 
Table RA17: Testing for Time-Fixed Effects LSDV Regressions (F- test for individual effects)

Dependent Variable: Logarithm of Industrial Earnings per Unit

\begin{tabular}{|l|l|l|c|c|}
\hline Equation & \multicolumn{1}{|c|}{$\begin{array}{c}\mathbf{H}_{\mathbf{0}}: \\
\text { Null } \\
\text { Hypothesis }\end{array}$} & $\begin{array}{c}\mathbf{H}_{\mathbf{1}} \text { : } \\
\text { Alternative } \\
\text { Hypothesis }\end{array}$ & F-statistics & p-value \\
\hline Model1 & No Time Fixed Effects & $\begin{array}{l}\text { Presence of Time } \\
\text { Fixed Effects }\end{array}$ & 16.76 & 0.01 \\
\hline Model2 & No Time Fixed Effects & $\begin{array}{l}\text { Presence of Time } \\
\text { Fixed Effects }\end{array}$ & 15.06 & 0.01 \\
\hline Model3 & No Time Fixed Effects & $\begin{array}{l}\text { Presence of Time } \\
\text { Fixed Effects }\end{array}$ & 18.63 & 0.01 \\
\hline
\end{tabular}

Source: Author computed 
Table RA18: Testing for Time-Fixed Effects LSDV Regressions (F- test for individual effects)

Dependent Variable: Logarithm of Public School Enrollment per Capita

\begin{tabular}{|l|l|l|c|c|}
\hline Equation & \multicolumn{1}{|c|}{$\begin{array}{c}\mathbf{H}_{\mathbf{0}}: \\
\text { Null } \\
\text { Hypothesis }\end{array}$} & $\begin{array}{c}\mathbf{H}_{\mathbf{1}}: \\
\text { Alternative } \\
\text { Hypothesis }\end{array}$ & F-statistics & p-value \\
\hline Model1 & No Time Fixed Effects & $\begin{array}{l}\text { Presence of Time } \\
\text { Fixed Effects }\end{array}$ & 270.47 & 0.01 \\
\hline Model2 & No Time Fixed Effects & $\begin{array}{l}\text { Presence of Time } \\
\text { Fixed Effects }\end{array}$ & 267.53 & 0.01 \\
\hline Mode13 & No Time Fixed Effects & $\begin{array}{l}\text { Presence of Time } \\
\text { Fixed Effects }\end{array}$ & 236.94 & 0.01 \\
\hline Mode14 & No Time Fixed Effects & $\begin{array}{l}\text { Presence of Time } \\
\text { Fixed Effects }\end{array}$ & 95.68 & 0.01 \\
\hline Model5 & No Time Fixed Effects & $\begin{array}{l}\text { Presence of Time } \\
\text { Fixed Effects }\end{array}$ & 317.09 & 0.01 \\
\hline
\end{tabular}

Source: Author computed 
Table RA19: Hausman Specification Tests ${ }^{39}$

\begin{tabular}{|c|c|c|c|c|}
\hline $\begin{array}{l}\text { Equation with the } \\
\text { Dependent } \\
\text { Variable }\end{array}$ & $\begin{array}{c}\mathrm{H}_{0}: \\
\text { Null } \\
\text { Hypothesis }\end{array}$ & $\begin{array}{c}\mathrm{H}_{1} \text { : } \\
\text { Alternative } \\
\text { Hypothesis } \\
\end{array}$ & $\begin{array}{l}\text { Chi-Square } \\
\text { statistics }\end{array}$ & p-value \\
\hline $\begin{array}{l}\text { Logarithm of } \\
\text { Income per Capita }\end{array}$ & $\begin{array}{l}\text { Preferred Model is } \\
\text { Random Effects } \\
\text { Model }\end{array}$ & $\begin{array}{l}\text { Preferred Model is } \\
\text { Fixed Effects } \\
\text { Model }\end{array}$ & 22.51 & 0.01 \\
\hline $\begin{array}{l}\text { Logarithm of Total } \\
\text { Industry Average } \\
\text { Wage }\end{array}$ & $\begin{array}{l}\text { Preferred Model is } \\
\text { Random Effects } \\
\text { Model }\end{array}$ & $\begin{array}{l}\text { Preferred Model is } \\
\text { Fixed Effects } \\
\text { Model }\end{array}$ & 41.64 & 0.01 \\
\hline $\begin{array}{l}\text { Logarithm of } \\
\text { Poverty Rate }\end{array}$ & $\begin{array}{l}\text { Preferred Model is } \\
\text { Random Effects } \\
\text { Model }\end{array}$ & $\begin{array}{l}\text { Preferred Model is } \\
\text { Fixed Effects } \\
\text { Model }\end{array}$ & 25.64 & 0.01 \\
\hline $\begin{array}{l}\text { Logarithm of Public } \\
\text { School Enrollment } \\
\text { per Capita }\end{array}$ & $\begin{array}{l}\text { Preferred Model is } \\
\text { Random Effects } \\
\text { Model }\end{array}$ & $\begin{array}{l}\text { Preferred Model is } \\
\text { Fixed Effects } \\
\text { Model }\end{array}$ & 44.67 & 0.01 \\
\hline $\begin{array}{l}\text { Logarithm of } \\
\text { Industry Earnings } \\
\text { per Industrial Unit }\end{array}$ & $\begin{array}{l}\text { Preferred Model is } \\
\text { Random Effects } \\
\text { Model }\end{array}$ & $\begin{array}{l}\text { Preferred Model is } \\
\text { Fixed Effects } \\
\text { Model }\end{array}$ & 42.56 & 0.01 \\
\hline $\begin{array}{l}\text { Patents per STEM } \\
\text { unit }\end{array}$ & $\begin{array}{l}\text { Preferred Model is } \\
\text { Random Effects } \\
\text { Model }\end{array}$ & $\begin{array}{l}\text { Preferred Model is } \\
\text { Fixed Effects } \\
\text { Model }\end{array}$ & 26.65 & 0.01 \\
\hline
\end{tabular}

Source: Author computed

\footnotetext{
${ }^{39}$ The exact version of Null Hypothesis $\mathrm{H}_{0}$ : Random Effects is consistent under $\mathrm{H}_{0}$ and $\mathrm{H}_{1}$; The alternative hypothesis $\mathrm{H}_{1}$ : Random Effects model is inconsistent under $\mathrm{H}_{1}$ and Fixed effects is efficient under $\mathrm{H}_{1}$
} 
Table RA20: Testing for Normality of Residuals from Fixed Effects Panel Regressions

\begin{tabular}{|c|c|c|c|c|c|}
\hline Test & Equation & $\begin{array}{c}\mathrm{H}_{0}: \\
\text { Null } \\
\text { Hypothesis }\end{array}$ & $\begin{array}{c}\mathrm{H}_{1} \text { : } \\
\text { Alternative } \\
\text { Hypothesis }\end{array}$ & $\begin{array}{c}\text { Chi-Square/ } \\
\text { W-statistics }\end{array}$ & $\begin{array}{c}\text { p- } \\
\text { value }\end{array}$ \\
\hline \multirow[t]{6}{*}{$\begin{array}{l}\text { Jarque- } \\
\text { Bera }\end{array}$} & $\begin{array}{l}\text { Logarithm of Income } \\
\text { per Capita }\end{array}$ & $\begin{array}{l}\text { Residuals are } \\
\text { normally } \\
\text { distributed }\end{array}$ & $\begin{array}{l}\text { Residuals are not } \\
\text { normally } \\
\text { distributed }\end{array}$ & 4.37 & 0.11 \\
\hline & $\begin{array}{l}\text { Logarithm of Total } \\
\text { Industry Average } \\
\text { Wage }\end{array}$ & $\begin{array}{l}\text { Residuals are } \\
\text { normally } \\
\text { distributed }\end{array}$ & $\begin{array}{l}\text { Residuals are not } \\
\text { normally } \\
\text { distributed }\end{array}$ & 2.69 & 0.26 \\
\hline & $\begin{array}{l}\text { Logarithm of Poverty } \\
\text { Rate }\end{array}$ & $\begin{array}{l}\text { Residuals are } \\
\text { normally } \\
\text { distributed }\end{array}$ & $\begin{array}{l}\text { Residuals are not } \\
\text { normally } \\
\text { distributed }\end{array}$ & 0.98 & 0.61 \\
\hline & $\begin{array}{l}\text { Logarithm of Public } \\
\text { School Enrollment } \\
\text { per Capita }\end{array}$ & $\begin{array}{l}\text { Residuals are } \\
\text { normally } \\
\text { distributed }\end{array}$ & $\begin{array}{l}\text { Residuals are not } \\
\text { normally } \\
\text { distributed }\end{array}$ & 4.90 & 0.09 \\
\hline & $\begin{array}{l}\text { Logarithm of Industry } \\
\text { Earnings per } \\
\text { Industrial Unit }\end{array}$ & $\begin{array}{l}\text { Residuals are } \\
\text { normally } \\
\text { distributed }\end{array}$ & $\begin{array}{l}\text { Residuals are not } \\
\text { normally } \\
\text { distributed }\end{array}$ & 4.03 & 0.13 \\
\hline & $\begin{array}{l}\text { Patents per STEM } \\
\text { unit }\end{array}$ & $\begin{array}{l}\text { Residuals are } \\
\text { normally } \\
\text { distributed }\end{array}$ & $\begin{array}{l}\text { Residuals are not } \\
\text { normally } \\
\text { distributed }\end{array}$ & 1.28 & 0.53 \\
\hline \multirow[t]{6}{*}{$\begin{array}{l}\text { Shapiro- } \\
\text { Wilk }\end{array}$} & $\begin{array}{l}\text { Logarithm of Income } \\
\text { per Capita }\end{array}$ & $\begin{array}{l}\text { Residuals are } \\
\text { normally } \\
\text { distributed }\end{array}$ & $\begin{array}{l}\text { Residuals are not } \\
\text { normally } \\
\text { distributed }\end{array}$ & 0.99 & 0.13 \\
\hline & $\begin{array}{l}\text { Logarithm of Total } \\
\text { Industry Average } \\
\text { Wage }\end{array}$ & $\begin{array}{l}\text { Residuals are } \\
\text { normally } \\
\text { distributed }\end{array}$ & $\begin{array}{l}\text { Residuals are not } \\
\text { normally } \\
\text { distributed }\end{array}$ & 0.99 & 0.16 \\
\hline & $\begin{array}{l}\text { Logarithm of Poverty } \\
\text { Rate }\end{array}$ & $\begin{array}{l}\text { Residuals are } \\
\text { normally } \\
\text { distributed }\end{array}$ & $\begin{array}{l}\text { Residuals are not } \\
\text { normally } \\
\text { distributed }\end{array}$ & 0.98 & 0.19 \\
\hline & $\begin{array}{l}\text { Logarithm of Public } \\
\text { School Enrollment } \\
\text { per Capita }\end{array}$ & $\begin{array}{l}\text { Residuals are } \\
\text { normally } \\
\text { distributed }\end{array}$ & $\begin{array}{l}\text { Residuals are not } \\
\text { normally } \\
\text { distributed }\end{array}$ & 0.97 & 0.12 \\
\hline & $\begin{array}{l}\text { Logarithm of Industry } \\
\text { Earnings per } \\
\text { Industrial Unit }\end{array}$ & $\begin{array}{l}\text { Residuals are } \\
\text { normally } \\
\text { distributed }\end{array}$ & $\begin{array}{l}\text { Residuals are not } \\
\text { normally } \\
\text { distributed }\end{array}$ & 0.97 & 0.13 \\
\hline & $\begin{array}{l}\text { Patents per STEM } \\
\text { unit }\end{array}$ & $\begin{array}{l}\text { Residuals are } \\
\text { normally } \\
\text { distributed }\end{array}$ & $\begin{array}{l}\text { Residuals are not } \\
\text { normally } \\
\text { distributed }\end{array}$ & 0.99 & 0.11 \\
\hline
\end{tabular}

Source: Author computed

${ }^{40}$ Chi-Square Statistics for Jarque-Bera Test and W-statistics for Shapiro-Wilk Test 
Table RA21: Breusch-Pagan Test of Independence Tests for Panel Seemingly Unrelated Regression (SUR) Model

\begin{tabular}{|l|l|c|c|}
\hline \multicolumn{1}{|c|}{$\begin{array}{c}\mathbf{H}_{\mathbf{0}} \text { : } \\
\text { Null } \\
\text { Hypothesis }\end{array}$} & \multicolumn{1}{c|}{$\begin{array}{c}\mathbf{H}_{\mathbf{1}} \text { : } \\
\text { Alternative Hypothesis }\end{array}$} & $\begin{array}{l}\text { Chi-Square } \\
\text { statistics }\end{array}$ & p-value \\
\hline $\begin{array}{l}\text { No Cross Equation Error- } \\
\text { Correlation among the system } \\
\text { of six equations }\end{array}$ & $\begin{array}{l}\text { Presence of Cross } \\
\text { Equation Error } \\
\text { Correlation among the } \\
\text { system of six equations }\end{array}$ & 267.79 & 0.01 \\
\hline
\end{tabular}

Source: Author computed 
Table RA22: Testing for Normality of Residuals for Panel Seemingly Unrelated Regression (SUR) Models

\begin{tabular}{|c|c|c|c|c|c|}
\hline Test & Equation & $\begin{array}{c}\mathrm{H}_{0}: \\
\text { Null } \\
\text { Hypothesis }\end{array}$ & $\begin{array}{c}\mathrm{H}_{1} \text { : } \\
\text { Alternative } \\
\text { Hypothesis }\end{array}$ & $\begin{array}{l}\text { Chi-Square/ } \\
\text { W - } \\
\text { statistics }^{41}\end{array}$ & $\begin{array}{l}\text { p- } \\
\text { value }\end{array}$ \\
\hline $\begin{array}{l}\text { Jarque- } \\
\text { Bera }\end{array}$ & $\begin{array}{l}\text { System of } \\
\text { Equation with } \\
\text { Six } \\
\text { Development } \\
\text { Indicators } \\
\end{array}$ & $\begin{array}{l}\text { Residuals are } \\
\text { normally } \\
\text { distributed }\end{array}$ & $\begin{array}{l}\text { Residuals are } \\
\text { not normally } \\
\text { distributed }\end{array}$ & 1.72 & 0.42 \\
\hline $\begin{array}{l}\text { Shapiro- } \\
\text { Wilk }\end{array}$ & $\begin{array}{l}\text { System of } \\
\text { Equation with } \\
\text { Six } \\
\text { Development } \\
\text { Indicators }\end{array}$ & $\begin{array}{l}\text { Residuals are } \\
\text { normally } \\
\text { distributed }\end{array}$ & $\begin{array}{l}\text { Residuals are } \\
\text { not normally } \\
\text { distributed }\end{array}$ & 0.97 & 0.09 \\
\hline
\end{tabular}

Source: Author computed

${ }^{41}$ Chi-Square Statistics for Jarque-Bera Test and W-statistics for Shapiro-Wilk Test 
Table RA23: Moran's I Test for Spatial Autocorrelation

\begin{tabular}{|c|c|c|c|c|}
\hline Equation & $\begin{array}{c}\mathrm{H}_{0}: \\
\text { Null } \\
\text { Hypothesis }\end{array}$ & $\begin{array}{c}\mathrm{H}_{1} \text { : } \\
\text { Alternative } \\
\text { Hypothesis }\end{array}$ & $\begin{array}{l}\text { Moran's I } \\
\text { Statistics }\end{array}$ & p-value \\
\hline $\begin{array}{l}\text { Logarithm of Income } \\
\text { per Capita }\end{array}$ & $\begin{array}{l}\text { No Spatial } \\
\text { Autocorrelation } \\
(\mathrm{I}=0)\end{array}$ & $\begin{array}{l}\text { Spatial } \\
\text { Autocorrelation } \\
\text { Exists }(I>0)\end{array}$ & 0.03 & 0.04 \\
\hline $\begin{array}{l}\text { Logarithm of Total } \\
\text { Industry Average } \\
\text { Wage }\end{array}$ & $\begin{array}{l}\text { No Spatial } \\
\text { Autocorrelation } \\
(\mathrm{I}=0)\end{array}$ & $\begin{array}{l}\text { Spatial } \\
\text { Autocorrelation } \\
\text { Exists }(I>0)\end{array}$ & 0.17 & 0.01 \\
\hline $\begin{array}{l}\text { Logarithm of Poverty } \\
\text { Rate }\end{array}$ & $\begin{array}{l}\text { No Spatial } \\
\text { Autocorrelation } \\
(\mathrm{I}=0)\end{array}$ & $\begin{array}{l}\text { Spatial } \\
\text { Autocorrelation } \\
\text { Exists }(I>0)\end{array}$ & 0.10 & 0.01 \\
\hline $\begin{array}{l}\text { Logarithm of Public } \\
\text { School Enrollment } \\
\text { per Capita }\end{array}$ & $\begin{array}{l}\text { No Spatial } \\
\text { Autocorrelation } \\
(\mathrm{I}=0)\end{array}$ & $\begin{array}{l}\text { Spatial } \\
\text { Autocorrelation } \\
\text { Exists }(I>0)\end{array}$ & 0.08 & 0.01 \\
\hline $\begin{array}{l}\text { Logarithm of Industry } \\
\text { Earnings per } \\
\text { Industrial Unit }\end{array}$ & $\begin{array}{l}\text { No Spatial } \\
\text { Autocorrelation } \\
(\mathrm{I}=0)\end{array}$ & $\begin{array}{l}\text { Spatial } \\
\text { Autocorrelation } \\
\text { Exists }(I>0)\end{array}$ & 0.09 & 0.01 \\
\hline $\begin{array}{l}\text { Patents per STEM } \\
\text { unit }\end{array}$ & $\begin{array}{l}\text { No Spatial } \\
\text { Autocorrelation } \\
(\mathrm{I}=0)\end{array}$ & $\begin{array}{l}\text { Spatial } \\
\text { Autocorrelation } \\
\text { Exists }(I>0)\end{array}$ & 0.04 & 0.05 \\
\hline
\end{tabular}

Source: Author computed 
Table RA24: Test for Suitable Spatial Fixed Effects Models

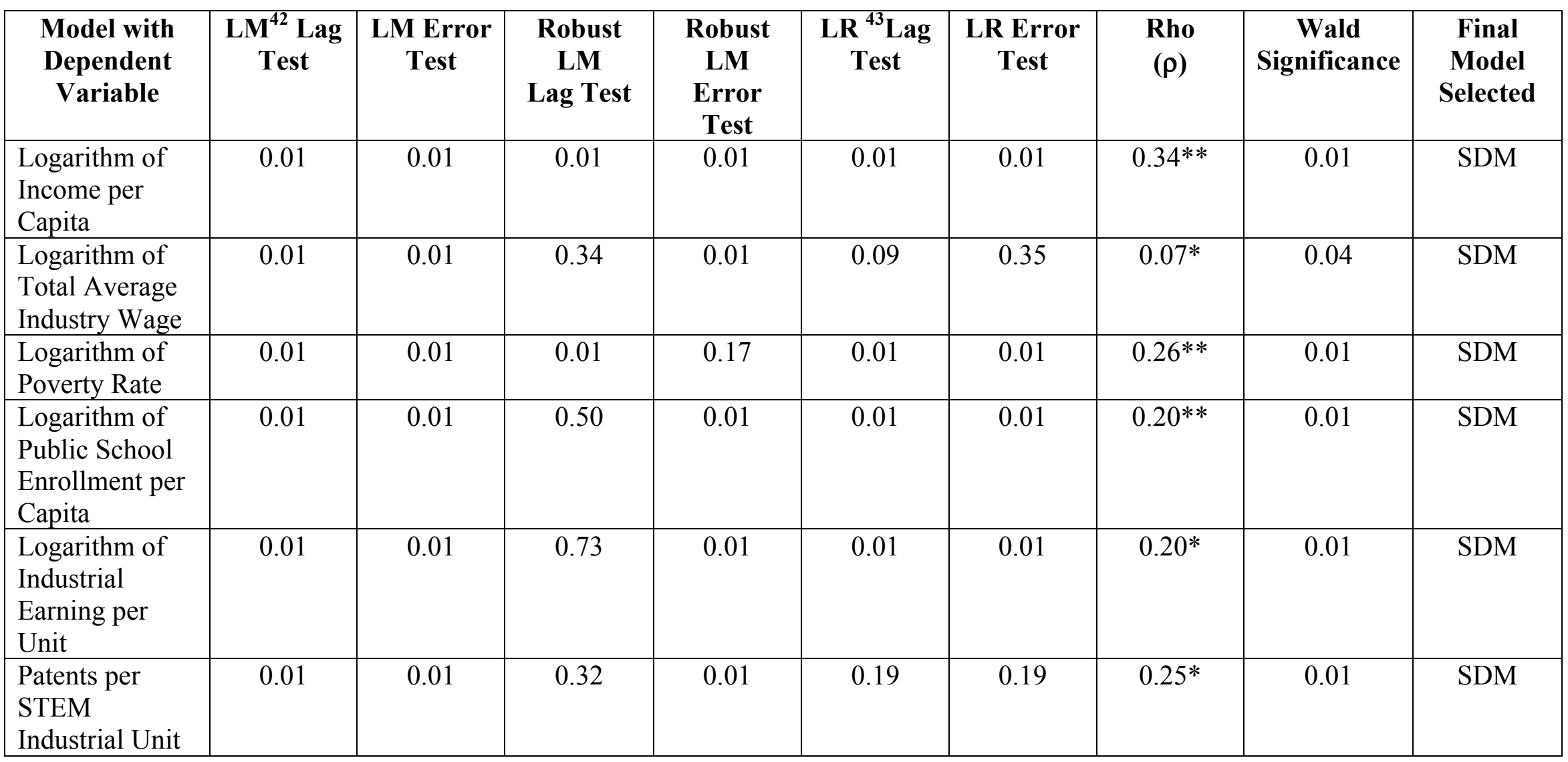

Note: The values reported in the above table are p-values from LR, LM and Wald Tests except the value of Rho( $\rho)$. (**) and $(*)$ suggest significant at $5 \%$ or below and $1 \%$ or below levels of significant in Chi-square test

\footnotetext{
${ }^{42}$ LM suggests Spatial Lagrange Multiplier Test

${ }^{43}$ LR Suggests Spatial Likelihood Ratio Test
} 
Table RA25: Hausman Specification Tests for Spatial Panel 44

\begin{tabular}{|c|c|c|c|c|}
\hline $\begin{array}{l}\text { Equation with the } \\
\text { Dependent } \\
\text { Variable }\end{array}$ & $\begin{array}{c}\mathrm{H}_{0}: \\
\text { Null } \\
\text { Hypothesis }\end{array}$ & $\begin{array}{c}\mathrm{H}_{1} \text { : } \\
\text { Alternative } \\
\text { Hypothesis } \\
\end{array}$ & $\begin{array}{l}\text { Chi-Square } \\
\text { statistics }\end{array}$ & p-value \\
\hline $\begin{array}{l}\text { Logarithm of } \\
\text { Income per Capita }\end{array}$ & $\begin{array}{l}\text { Preferred Model is } \\
\text { Random Effects } \\
\text { Model }\end{array}$ & $\begin{array}{l}\text { Preferred Model is } \\
\text { Fixed Effects } \\
\text { Model }\end{array}$ & 34.04 & 0.01 \\
\hline $\begin{array}{l}\text { Logarithm of Total } \\
\text { Industry Average } \\
\text { Wage }\end{array}$ & $\begin{array}{l}\text { Preferred Model is } \\
\text { Random Effects } \\
\text { Model }\end{array}$ & $\begin{array}{l}\text { Preferred Model is } \\
\text { Fixed Effects } \\
\text { Model }\end{array}$ & 22.66 & 0.01 \\
\hline $\begin{array}{l}\text { Logarithm of } \\
\text { Poverty Rate }\end{array}$ & $\begin{array}{l}\text { Preferred Model is } \\
\text { Random Effects } \\
\text { Model }\end{array}$ & $\begin{array}{l}\text { Preferred Model is } \\
\text { Fixed Effects } \\
\text { Model }\end{array}$ & 50.71 & 0.01 \\
\hline $\begin{array}{l}\text { Logarithm of Public } \\
\text { School Enrollment } \\
\text { per Capita }\end{array}$ & $\begin{array}{l}\text { Preferred Model is } \\
\text { Random Effects } \\
\text { Model }\end{array}$ & $\begin{array}{l}\text { Preferred Model is } \\
\text { Fixed Effects } \\
\text { Model }\end{array}$ & 49.18 & 0.01 \\
\hline $\begin{array}{l}\text { Logarithm of } \\
\text { Industry Earnings } \\
\text { per Industrial Unit }\end{array}$ & $\begin{array}{l}\text { Preferred Model is } \\
\text { Random Effects } \\
\text { Model }\end{array}$ & $\begin{array}{l}\text { Preferred Model is } \\
\text { Fixed Effects } \\
\text { Model }\end{array}$ & 20.83 & 0.01 \\
\hline $\begin{array}{l}\text { Patents per STEM } \\
\text { unit }\end{array}$ & $\begin{array}{l}\text { Preferred Model is } \\
\text { Random Effects } \\
\text { Model }\end{array}$ & $\begin{array}{l}\text { Preferred Model is } \\
\text { Fixed Effects } \\
\text { Model }\end{array}$ & 19.53 & 0.03 \\
\hline
\end{tabular}

Source: Author computed

\footnotetext{
${ }^{44}$ The exact version of Null Hypothesis $\mathrm{H}_{0}$ : Random Effects is consistent under $\mathrm{H}_{0}$ and $\mathrm{H}_{1}$; The alternative hypothesis $\mathrm{H}_{1}$ : Random Effects model is inconsistent under $\mathrm{H}_{1}$ and Fixed effects is efficient under $\mathrm{H}_{1}$
} 
Table RA26: Testing for Normality of Residuals from Fixed Effects Spatial Panel Regressions

\begin{tabular}{|c|c|c|c|c|c|}
\hline Test & Equation & $\begin{array}{c}\mathrm{H}_{0}: \\
\text { Null } \\
\text { Hypothesis }\end{array}$ & $\begin{array}{l}\qquad \mathrm{H}_{1} \text { : } \\
\text { Alternative } \\
\text { Hypothesis }\end{array}$ & $\begin{array}{l}\text { Chi-Square/ } \\
\text { W -statistics }\end{array}$ & $\begin{array}{l}p- \\
\text { value }\end{array}$ \\
\hline \multirow[t]{6}{*}{$\begin{array}{l}\text { Jarque- } \\
\text { Bera }\end{array}$} & $\begin{array}{l}\text { Logarithm of } \\
\text { Income per Capita }\end{array}$ & $\begin{array}{l}\text { Residuals are } \\
\text { normally } \\
\text { distributed }\end{array}$ & $\begin{array}{l}\text { Residuals are not } \\
\text { normally } \\
\text { distributed }\end{array}$ & 1.19 & 0.55 \\
\hline & $\begin{array}{l}\text { Logarithm of Total } \\
\text { Industry Average } \\
\text { Wage }\end{array}$ & $\begin{array}{l}\text { Residuals are } \\
\text { normally } \\
\text { distributed }\end{array}$ & $\begin{array}{l}\text { Residuals are not } \\
\text { normally } \\
\text { distributed }\end{array}$ & 4.89 & 0.09 \\
\hline & $\begin{array}{l}\text { Logarithm of } \\
\text { Poverty Rate }\end{array}$ & $\begin{array}{l}\text { Residuals are } \\
\text { normally } \\
\text { distributed }\end{array}$ & $\begin{array}{l}\text { Residuals are not } \\
\text { normally } \\
\text { distributed }\end{array}$ & 1.98 & 0.37 \\
\hline & $\begin{array}{l}\text { Logarithm of Public } \\
\text { School Enrollment } \\
\text { per Capita }\end{array}$ & $\begin{array}{l}\text { Residuals are } \\
\text { normally } \\
\text { distributed }\end{array}$ & $\begin{array}{l}\text { Residuals are not } \\
\text { normally } \\
\text { distributed }\end{array}$ & 3.59 & 0.17 \\
\hline & $\begin{array}{l}\text { Logarithm of } \\
\text { Industry Earnings } \\
\text { per Industrial Unit }\end{array}$ & $\begin{array}{l}\text { Residuals are } \\
\text { normally } \\
\text { distributed }\end{array}$ & $\begin{array}{l}\text { Residuals are not } \\
\text { normally } \\
\text { distributed }\end{array}$ & 3.10 & 0.21 \\
\hline & $\begin{array}{l}\text { Patents per STEM } \\
\text { unit }\end{array}$ & $\begin{array}{l}\text { Residuals are } \\
\text { normally } \\
\text { distributed } \\
\end{array}$ & $\begin{array}{l}\text { Residuals are not } \\
\text { normally } \\
\text { distributed } \\
\end{array}$ & 1.75 & 0.78 \\
\hline \multirow[t]{6}{*}{$\begin{array}{l}\text { Shapiro- } \\
\text { Wilk }\end{array}$} & $\begin{array}{l}\text { Logarithm of } \\
\text { Income per Capita }\end{array}$ & $\begin{array}{l}\text { Residuals are } \\
\text { normally } \\
\text { distributed }\end{array}$ & $\begin{array}{l}\text { Residuals are not } \\
\text { normally } \\
\text { distributed }\end{array}$ & 0.97 & 0.09 \\
\hline & $\begin{array}{l}\text { Logarithm of Total } \\
\text { Industry Average } \\
\text { Wage }\end{array}$ & $\begin{array}{l}\text { Residuals are } \\
\text { normally } \\
\text { distributed }\end{array}$ & $\begin{array}{l}\text { Residuals are not } \\
\text { normally } \\
\text { distributed }\end{array}$ & 0.99 & 0.16 \\
\hline & $\begin{array}{l}\text { Logarithm of } \\
\text { Poverty Rate }\end{array}$ & $\begin{array}{l}\text { Residuals are } \\
\text { normally } \\
\text { distributed } \\
\end{array}$ & $\begin{array}{l}\text { Residuals are not } \\
\text { normally } \\
\text { distributed }\end{array}$ & 0.98 & 0.19 \\
\hline & $\begin{array}{l}\text { Logarithm of Public } \\
\text { School Enrollment } \\
\text { per Capita }\end{array}$ & $\begin{array}{l}\text { Residuals are } \\
\text { normally } \\
\text { distributed } \\
\end{array}$ & $\begin{array}{l}\text { Residuals are not } \\
\text { normally } \\
\text { distributed }\end{array}$ & 0.96 & 0.07 \\
\hline & $\begin{array}{l}\text { Logarithm of } \\
\text { Industry Earnings } \\
\text { per Industrial Unit }\end{array}$ & $\begin{array}{l}\text { Residuals are } \\
\text { normally } \\
\text { distributed }\end{array}$ & $\begin{array}{l}\text { Residuals are not } \\
\text { normally } \\
\text { distributed }\end{array}$ & 0.97 & 0.13 \\
\hline & $\begin{array}{l}\text { Patents per STEM } \\
\text { unit }\end{array}$ & $\begin{array}{l}\text { Residuals are } \\
\text { normally } \\
\text { distributed } \\
\end{array}$ & $\begin{array}{l}\text { Residuals are not } \\
\text { normally } \\
\text { distributed }\end{array}$ & 0.99 & 0.11 \\
\hline
\end{tabular}

Source: Author computed

${ }^{45}$ Chi-Square Statistics for Jarque-Bera Test and W-statistics for Shapiro-Wilk Test 